\title{
Revision of the diatom genus Sellaphora: a first account of the larger species in the British Isles
}

\author{
David G. ManN*, Sindu J. Thomas \& Katharine M. Evans \\ Royal Botanic Garden Edinburgh, Inverleith Row, Edinburgh EH3 5LR, Scotland, UK \\ *David G. Mann,d.mann@rbge.org.uk
}

\begin{abstract}
As a step towards a global monograph of the freshwater diatom genus Sellaphora, we made detailed surveys of Sellaphora diversity in the epipelon of 38 lakes and ponds and three Holocene diatomites in the British Isles, restricting our analysis to those specimens that would be classified in S. americana, S. bacillum, S. pupula or S. laevissima according to the standard European diatom flora of KRAMMER \& LANGE-BERTALOT (1986; Süsswasserflora von Mitteleuropa, vol. 2/1. - G. Fischer, Stuttgart \& New York). From a total of c. $10^{4}$ specimens observed, over 3200 were recorded as digital images and sorted into 54 mostly informally-named phenodemes that can act as operational taxonomic units during future revisions. Of the 54 phenodemes, c. 40 are well-differentiated, while the others seem to intergrade and are in particular need of further study using morphometric, molecular and mating approaches. The limitations of conventional diatom taxonomy by visual comparison are clearly demonstrated. To help standardize identifications, published DNA sequences are assigned to some of the demes as 'molecular barcode'. The phenodemes of S. pupula sensu lato cannot be equated with the infraspecific taxa previously recorded for the British Isles and both these and most other pre-1990 records of species now assigned to Sellaphora must be regarded as having very little value for ecological and biogeographical purposes. Possible non-British records of the phenodemes are discussed but few are totally convincing; of those records most likely to be of the same phenodemes, the majority come from elsewhere in Europe.
\end{abstract}

Key words: Bacillariophyta, biogeography, diatoms, DNA BARCODE, iconograph, Sellaphora, taxonomy

\section{Introduction}

This paper represents a small but we hope significant step towards a revision of the genus Sellaphora MERESCHK. It deals with four common freshwater diatoms, each regarded as a single species before the 1990s but now shown to be heterogeneous through the use of morphological, mating or molecular genetic data. The four will be referred to here as the 'pupula', 'bacillum', 'laevissima' and 'americana' groups, using the species names most often used for them within Sellaphora and Navicula Bory. Ideally, diatom genera should be studied and revised on a world-wide scale, especially because biogeographical patterns are weak above the species level, and possibly at this level too. Our original aim was therefore to produce a global account, but we have reluctantly accepted that this is impractical. To produce within a few years a world monograph of even a modestly sized diatom genus such as Sellaphora requires resources of expertise, collections and research effort that are not available to us; it also needs the good fortune that others do not unknowingly duplicate the work and publish first. Some of the phenodemes we describe here have been known to us, and drawn or photographed, for more than 20 years (ManN \& Droop 1996, D.G. ManN, unpublished data); it is time that these 'hypothesized taxonomic units' (putative species) were made available for evaluation.

In this paper, we restrict ourselves to the demes and species in the four species complexes that we have found during a survey of c. 40 sites in Britain and Northern Ireland. However, we admit at the outset that our survey is far from complete and the catalogue of diversity is almost certainly not exhaustive, even for the area chosen.

Historical review: Individual species of Sellaphora have been known for up to 170 years, but for most of this period they were classified in the genus Navicula BorY, which was then a 'catchall' grouping of simply-structured, bilaterally symmetrical, raphid diatoms. The species destined to become the type of Sellaphora, Navicula 
pupula, was described in 1844 by F.T. KüTZING, who also described $N$. laevissima. Shortly before this, the epithet of another commonly recorded species, Sellaphora bacillum, was established by EHRENBERG (1839, as N. bacillum), and EHRENBERG (1843) added $N$. americana. These four longestestablished species are also the most commonly recorded species of Sellaphora, apart from $S$. seminulum. However, the original descriptions were less important in establishing taxonomic usage than later floras and papers, particularly those by Van Heurck (1880-1885), Cleve (1894) and HustedT (1930).

During most of the 19th and 20th centuries, diatom taxonomy was based almost entirely on the structure of the frustule (the silicified cell wall of diatoms); other features, such as chloroplast morphology, reproductive characteristics or nuclear behaviour, were rarely considered until the 1980s (the few exceptions include e.g. GeITLER 1973). There is nothing particularly unusual about the structure of the frustule in Sellaphora that sets it apart from all other 'naviculoid' diatoms, in contrast, for example, to the partecta of Mastogloia or the longitudinal canals of Diploneis. Hence the original classification of Sellaphora species in Navicula is wholly understandable. However, if chloroplast morphology is taken into account, differences between Sellaphora and Navicula species are immediately apparent. This was first noticed by MERESCHKOWSKY (1902).

Among 19th and early 20th century diatomists, almost the only one to take chloroplast morphology seriously as a source of taxonomic information was the eccentric Russian biologist Konstantin Sergeevich MerezhKovskij (MereSCHKOWSKY), better known today for his prescient ideas on the endosymbiotic origin of chloroplasts (e.g. MereschKowsky 1905). In a few years (principally 1900-1906), MeresChKowsKy published a series of remarkable papers on chloroplast morphology, chloroplast division and sexual reproduction in diatoms, in which he developed new ideas about systematic relationships and diatom evolution. He also established several new genera, including Sellaphora, for which he gave the following description (MERESCHKOWSKY 1902, p. 186):

'Valve small, symmetrical, linear to elliptical, with obtuse ends, terminal nodules distant; striae usually fine, connecting-zone simple. Endochrome composed of one plate, resting with its narrow median part on the surface of one of the valves, with four long prolongations along the connecting zones. Pyrenoid absent. A few elaeoplasts, sometimes represented by two libroplasts.'

The key feature was the shape of the chloroplast ('endochrome'), which is a single H-shaped plate; it is this that gives the genus its name (Sellaphora $=$ 'saddle-bearer'). MereschKowsky (1902) assigned four species to the genus, two from freshwater - S. pupula and S. laevissima (which he called $S$. bacilliformis) - and two from the Black Sea $-S$. borscowii and S. elliptica. The type species is S. pupula (ManN 1989a, 2001). The identities of the Black Sea species are currently unknown: the original descriptions and illustrations give little information about valve morphology and MereschKowsky's collections (if, indeed, he ever kept preserved material) appear not to have survived after his flight to France, then Switzerland, in 1914 (Stafleu \& Cowan 1981, Sapp et al. 2002). It is quite possible that $S$. borscowii and $S$. elliptica belong to the related genus Fallacia. All other known Sellaphora species are restricted to fresh waters.

Otto MüLLER was the only early $20^{\text {th }}$ century diatomist to take MERESCHKOWSKY's work seriously and published a few new species that he thought might belong to Sellaphora, following studies of diatoms from Lake Malawi (the Nyassa-See) and nearby parts of E Africa (MüLLER 1910). Most other $20^{\text {th }}$ century floras did not mention Sellaphora or recognize it as separate from other Navicula species at any level (e.g. HUSTEDT 1930, 1961, Cleve-Euler 1953, Patrick \& Reimer 1966, Germain 1981, Krammer \& LangeBertalot 1986). Furthermore, in infrageneric classifications of Navicula, the species now assigned to Sellaphora (see below) were not always put in the same group. An early classification by Grunow (in Cleve \& GRunow 1880) placed them together in the 'Gruppe: Minutulae', but Cleve (1894) put some in sect. Bacillares and others, including the type species $S$. pupula, in sect. Mesoleiae, although he noted that the two sections were 'closely connected'. Hustedt (1930) and Cleve-Euler (1953) also split Sellaphora species between Navicula sects Bacillares and Mesoleiae, although Hustedt treated $S$. pupula as a member of the Bacillares. Later, Hustedt (1961) placed most Sellaphora species and several unrelated naviculoid diatoms in an expanded sect. Bacillares, whereas Navicula perhibita (which has yet 
to be transferred to Sellaphora) was classified in the Naviculae microstigmaticae (HustedT 1962). Germain (1981) and Patrick \& ReImer (1966) adopted a narrower concept of the sect. Bacillares (raised to the subgenus Bacillum by PATRICK 1959) than HustedT, in which all the larger-celled species that we treat in this paper were included, but not several others now assigned to Sellaphora, which were placed in the section Minusculae or subgenus Minuscula. Krammer \& Lange-BertaLOT (1986) returned to a classification resembling that of Hustedt (1961).

\section{Resurrection of Sellaphora as an independent} genus: In the 1970s and 1980s, new information from scanning electron microscopy (SEM) suggested that Navicula was not only large and highly variable, but probably also polyphyletic. However, although SEM provided many new insights and suggested how some existing genera might be remodelled (e.g. MeduIN \& Round 1986 for gomphonemoid diatoms), in many cases evolutionary relationships were unclear because of character conflicts. Partly because of this and partly because the prevailing taxonomic philosophy was then phenetic, with its requirement that taxonomic judgments should reflect 'overall similarity' based on all available evidence, several di- atomists started to look for alternative sources of information, including cytological and reproductive characteristics. During this phase, Sellaphora was reinstated as a separate genus (MANN 1989a, Round et al. 1990). Since then, the phenetic approach has been discredited for phylogeny reconstruction and powerful molecular genetic tools have become available for determining evolutionary relationships, but the basic concept of Sellaphora developed by MANN (1989a) has withstood all tests so far (e.g. BeHNKE et al. 2004, MANn et al. 2004, Jones et al. 2005, Evans et al. 2007, 2008).

MANN's (1989a) revised description is given in Table 1. It was based on detailed observations of about 10 species, but nearly 20 years of further research has not added anything of significance with respect to the cytological and morphological characteristics listed. However, some species have now been found to be auto- or apomictic, producing auxospores without prior pairing and gamete exchange (MANn 1999, MANn et al. 2004, and unpublished observations of A. PouLíčKovÁ, V.A. Chepurnov and D.G. ManN); in these, characters $8-10$ of Table 1 are modified or absent.

Very few of the individual characters listed in Table 1 are unique to Sellaphora. That does not necessarily mean that they are not synapomorphies for Sellaphora, only that similar char-

Table 1. Characteristics of Sellaphora according to the provisional description by MANN (1989).

\begin{tabular}{ll}
\hline 1. & Internal central raphe endings deflected towards the primary side of the valve. \\
\hline 2. & Poroids small, round, containing hymenes. \\
\hline 3. & Plastid single, H-shaped, lying with its centre against the epivalve. \\
\hline 4. & $\begin{array}{l}\text { Pyrenoid } \pm \text { tetrahedral during interphase, invaginated; one per plastid, lying on one side } \\
\text { of the plastid isthmus. }\end{array}$ \\
\hline 5. & Plastid translocated onto the girdle before mitosis. \\
\hline 7. & $\begin{array}{l}\text { Division of plastid beginning before cytokinesis and before the previous division is } \\
\text { complete, proceeding asymmetrically, and arresting before completion to produce the }\end{array}$ \\
\hline 8. & $\begin{array}{l}\text { H-shape of interphase. } \\
\text { throughout meiosis and plasmogamy; opening only partially to allow gamete migration } \\
\text { via a copulation aperture. }\end{array}$ \\
\hline 9. & $\begin{array}{l}\text { One functional gamete and one apochlorotic cell formed per gametangium. } \\
\text { Gametes physiologically anisogamous: auxospore formed within one gametangium and } \\
\text { expanding parallel to its apical axis. }\end{array}$ \\
\hline
\end{tabular}


acteristics have evolved independently in other, unrelated diatoms. For example, character 9 is shared by Eunotia (e.g. MANN et al. 2003) and must have been acquired independently. However, some of the characters may be symplesiomorphies, since they are shared by Fallacia, Rossia and the Pinnulariaceae, which are probably the closest relatives of Sellaphora (Evans et al. 2008). For example, invaginated pyrenoids are present in Fallacia, Caloneis and Pinnularia species (Tschermak-Woess 1953, Edgar 1980, ManN 1996, PoulíčKová et al. 2007, D.G. Mann \& A.J. STICKLE, unpublished observations). The combination of characters listed in Table 1, however, is apparently unique to Sellaphora.

Many of the characters in Table 1 concern the structure or activities of living cells. Indeed, it is impossible to assign a species to Sellaphora without information about the living cell or molecular genetic data, unless the cell wall possesses derived characters that link the diatom unambiguously to species already known to belong to the genus. For example, the Sellaphora pupula-bacillum group, but not most other Sellaphora species (e.g. S. americana, S. laevissima, S. seminulum, $S$. disjuncta) all possess small transverse bars internally near the ends of the valves (Fig. 1; MANN 1989a, fig. 5). Possession of such bars in a diatom with uniseriate striae of small round poroids and deflected internal central raphe endings allows species such as $S$. paenepupula (Metzeltin \& LANGe-Bertalot 2002) to be assigned to Sellaphora, despite the absence of information on the living cell and its life cycle. The senior author is nevertheless disappointed that no-one outside his research group (with the single exception of LEVKOV et al. 2006) seems to have checked chloroplast or reproductive features in any of the new or newly transferred species of Sellaphora. In order to make it easier for others to record and interpret living Sellaphora cells, we have now provided images and descriptions of the cell- and life-cycle on-line at http://rbg-web2.rbge.org.uk/algae/sellaphora.htm. However, in future, it may be more efficient to use DNA sequence data, rather than cytological detail, to check whether species belong to Sellaphora, especially in small-celled diatoms.

\section{Recent developments in Sellaphora systematics:} Since the resurrection of Sellaphora as an independent genus nearly 20 years ago (MANN 1989a), the number of recognized species has grown from eight to nearly 80 (Table 2 ). This is partly because of changes in the species concept (discussed by MANN 1999) but it also reflects a vigorous new phase of exploration and alpha taxonomy. The increase is consistent with the predictions made by MANN \& DROOP (1996) for the diatoms overall.

The first published molecular systematic investigations of Sellaphora were made by MANN and Guihal (in ManN 1999) and BehnKe et al. (2004), who confirmed earlier suspicions from mating data that species diversity in the genus has been seriously underestimated (MANN 1984, 1989b). Evans et al. (2007, 2008) have subsequently carried out molecular phylogenetic studies of Sellaphora through use of three genes, $18 \mathrm{~S}$ rDNA, $r b c \mathrm{~L}$ and $c o x 1$, which are located in the nucleus, chloroplast and mitochondrion, respectively. These studies have revealed a partial mismatch between genetic relationships and the traditional classification based on morphology, which can be illustrated by two examples. The first concerns $S$. bacillum and S. pupula, which share a characteristic uncommon among raphid diatoms, namely lateral extension of the terminal nodule to form short transverse bars at the poles (Fig. 1). Other characteristics differentiate these two species, which have been regarded as separate for 150 years. HuSTEDT's (1930) succinct formula for identification was:

"a. Zentralarea rundlich, nicht quer verbreitet. N. bacillum"

"b. Zentralarea querrechteckig

N. pupula"

Hustedt (1961) and Krammer \& LANGe-Bertalot (1986), on the other hand, focused more on the shape of the valves - linear-elliptical with broadly rounded apices in S. bacillum, but more lanceolate and with rostrate or capitate ends in S. pupula. From the historical taxonomy, one might expect that $S$. bacillum and $S$. pupula would be sister species or sister clades of species. Molecular data suggest instead that, although $S$. bacillum and $S$. pupula do indeed comprise a monophyletic group characterized morphologically by the polar bars, $S$. pupula is not monophyletic but paraphyletic with respect to $S$. bacillum.

The second example concerns those variants of $S$. pupula with linear or linear-elliptical ('lanceolate') valves and broad capitate or subcapitate apices. These have often been recognized taxonomically as 'var. capitata' (Hustedt 1930, PATRICK \& REIMER 1966, Germain 1981) or 'f. capitata' (Hustedt 1961) and this taxon is frequently recorded in surveys (e.g. Hustedt 1937-1939, 
Table 2. A list of all described species of Sellaphora known to us in December 2007. Taxon authors are abbreviated according to the International Plant Names Index (http://www.ipni.org/).

\begin{tabular}{|c|c|}
\hline Species & Phenotypic species group \\
\hline $\begin{array}{l}\text { Sellaphora alastos (M.H. Hohn et Hellerman) LANGe- } \\
\text { BERT. et METZELTin } 1996\end{array}$ & 'bacillum' group \\
\hline Sellaphora americana (EHRENB.) D.G. MANN 1989 & 'americana' group \\
\hline Sellaphora amoena Metzeltin et LANGe-BERT. 1998 & 'bacillum' group \\
\hline $\begin{array}{l}\text { Sellaphora auldreekie D.G. MANN et S.M. McDonALD } \\
\text { in D.G. MANN et al. } 2004\end{array}$ & 'pupula' group \\
\hline $\begin{array}{l}\text { Sellaphora bacillarioides (GRUNOw) N.A. ANDRESEN, } \\
\text { STOERMER et KREIS } 2000\end{array}$ & 'bacillum' group \\
\hline Sellaphora bacilliformis (GRUNOW) MERESCHK. 1902 & 'laevissima' group \\
\hline $\begin{array}{l}\text { Sellaphora bacilloides (HuST.) LEVKOV, KRSTIC et } \\
\text { NAKOV in LEVKOV et al. } 2006\end{array}$ & 'bacillum' group \\
\hline Sellaphora bacillum (EHRENB.) D.G. MANN 1989 & ‘bacillum' group \\
\hline $\begin{array}{l}\text { Sellaphora blackfordensis D.G. MANN et S. DROOP in } \\
\text { D.G. MANN et al. } 2004\end{array}$ & 'pupula' group \\
\hline Sellaphora borscowii MerEschK. 1902 & unknown; not Sellaphora? \\
\hline $\begin{array}{l}\text { Sellaphora californica PotAPOVA in PotAPOVA \& D.F. } \\
\text { CHARLES } 2004\end{array}$ & 'pupula' group \\
\hline $\begin{array}{c}\text { Sellaphora capitata D.G. MANN et S.M. MCDONALD in } \\
\text { D.G. MANN et al. } 2004\end{array}$ & 'pupula' group \\
\hline Sellaphora costei Metzeltin et LANGe-Bert. 1998 & 'bacillum' group \\
\hline $\begin{array}{l}\text { Sellaphora densistriata (LAnge-Bert. et Metzeltin) } \\
\text { Lange-Bert. et Metzeltin in MetZeltin \& } \\
\text { Lange-Bert. } 2002\end{array}$ & 'pupula' group \\
\hline Sellaphora disjuncta (Hust.) D.G. MANN 1989 & 'seminulum' group \\
\hline Sellaphora elliptica MereschK. 1902 & unknown; not Sellaphora? \\
\hline Sellaphora emilia Metzeltin et LANGe-BERT. 2007 & 'bacillum' group \\
\hline $\begin{array}{l}\text { Sellaphora fallacioides METzeltin, LANGE-BERT. et } \\
\text { GARcíA-RodRíGUEz } 2005\end{array}$ & probably belongs to Fallacia \\
\hline $\begin{array}{l}\text { Sellaphora fusticulus (ØSTRUP) LANGE-BERT. in RUMRICH } \\
\text { et al. } 2000\end{array}$ & 'laevissima' group \\
\hline $\begin{array}{l}\text { Sellaphora garciarodriguezii MetZeLtin et LANGE-BERT. } \\
\text { in Metzeltin et al. } 2005\end{array}$ & 'pupula' group \\
\hline Sellaphora gibbula Metzeltin et LANGe-Bert. 1998 & 'bacillum' group \\
\hline $\begin{array}{l}\text { Sellaphora gregoryana (Cleve et GRunow) Metzeltin } \\
\text { et LANGE-BERT. } 1998\end{array}$ & 'bacillum' group \\
\hline Sellaphora guyanensis Metzeltin et LANGe-Bert. 1998 & insufficient data: 'seminulum' group? \\
\hline $\begin{array}{c}\text { Sellaphora hustedtii (KRASSKE) LANGE-Bert. et WerUM } \\
\text { in WERUM et LANGE-BERT. } 2004\end{array}$ & insufficient data: 'seminulum' group? \\
\hline Sellaphora illustris Metzeltin et LANGE-Bert. 1998 & 'bacillum' group \\
\hline
\end{tabular}


Table 2 Cont.

Sellaphora joubaudii (H. Germ.) ABOAL in ABOAL et al. 2003

Sellaphora julma LANGE-Bert. et Metzeltin in Metzeltin \& Lange-Bert. 2002

Sellaphora krsticii Levkov, Nakov et Metzeltin 2006

Sellaphora laevissima (KÜTZ.) D.G. MANN 1989

Sellaphora lambda (Cleve) Metzeltin et Lange-Bert. 1998

Sellaphora lanceolata D.G. MANn et S. Droop in D.G. MANN et al. 2004

Sellaphora lange-bertalotii Metzeltin in Metzeltin \& LANGE-BERT. 2002

Sellaphora laterostellata Metzeltin et LANGE-BERT. 1998

Sellaphora laterostrata Metzeltin et Lange-Bert. 1998

Sellaphora macedonica LeVkov et Metzeltin in LEVKOV et al. 2007

Sellaphora madagascariensis Metzeltin et LANGEBERT. 2002

Sellaphora mantasoana Metzeltin et LANGe-Bert. 2002

Sellaphora mutata (KRASSKE) LANGE-Bert. in LANGEBERT. et al. 1996

Sellaphora mutatoides Lange-Bert. et Metzeltin in Metzeltin \& Lange-Bert. 2002

Sellaphora nana (Hust.) Lange-Bert., CAVAcini, Tagliaventi et Alfinito 2003

Sellaphora nanoides LANGe-BERT., CAVACINI, TAgliaventi et Alfinito 2003

Sellaphora neidioides (Manguin) Metzeltin et LangeBERT. 2007

Sellaphora nyassensis (O. MüLl.) D.G. MANN 1989

Sellaphora obesa D.G. MANN et M.M. BAYER in D.G. MANN et al. 2004

Sellaphora ohridana LeVKOV et KRSTIC in LeVKov et al. 2007

Sellaphora omuelleri Metzeltin et LANGe-Bert. 2002

Sellaphora paenepupula Metzeltin et LANGe-Bert. 2002

Sellaphora parapupula LANGE-BERT. in LANGE-BERT. \& MeTZELTIN 1996

Sellaphora perbacilloides Levkov, NAKov et Metzeltin 2006 insufficient data: 'seminulum' group?

'laevissima' group

'bacillum' group

'laevissima' group

'bacillum' group

'pupula' group

'pupula' group

'pupula' group

'pupula' group

'pupula' group

'bacillum' group

'pupula' group

'pupula' group

'pupula' group

insufficient data: may belong to 'seminulum' group or possibly even to Fallacia

insufficient data: may belong to 'seminulum' group or possibly even to Fallacia

probably belongs to Fallacia

'pupula' group

'pupula' group

'bacillum' group

'pupula' group

'pupula' group

'pupula' group

'bacillum' group 
Table 2 Cont.

Sellaphora pseudomutatoides LeVKov et Metzeltin in LEVKOV et al. 2007

Sellaphora pseudopupula (KRASSKE) LANGE-BERT. in LANGE-BERT. et al. 1996

Sellaphora pupula (Kütz.) MERESChK. 1902

Sellaphora rectangularis (W. GREG.) LANGE-BERT. et Metzeltin 1996

Sellaphora rectilinearis LANGE-BERT., CAVACINI, Tagliaventi et Alfinito 2003

Sellaphora renata Metzeltin et LANGe-Bert. 2007

Sellaphora reviersii LANGe-Bert. et Moser in Moser et al. 1995

Sellaphora rhombicarea Metzeltin, LANGE-BERT. et GARcíA-RodrígueZ 2005

Sellaphora riojae (CleVE) E. REICHARDt 1997

Sellaphora rioplatensis Metzeltin, LANGe-Bert. et García-RodríGUEZ 2005

Sellaphora rostrata (HuST.) J.R. JOHANSEN in J.R. JOHANSEN et al. 2004

Sellaphora ruppelii Metzeltin et Lange-Bert. 2007

Sellaphora santiagoi Metzeltin, Lange-Bert. et García-RodríGUEZ 2005

Sellaphora sardiniensis LANGE-Bert., CAVACINI, Tagliaventi et Alfinito 2003

Sellaphora seminulum (Grunow) D.G. MANN 1989

Sellaphora subantarctica VAN DE VIJVER et BEYENS in VAN DE VIJVER et al. 2002

Sellaphora subdeliberata (MANGUIN) E. REICHARDT 1997

Sellaphora sublinearis Metzeltin et Lange-Bert. 1998

Sellaphora subpupula Levkov et NAKOv in Levkov et al. 2007

Sellaphora tapajosensis Metzeltin et LANGE-BERT. 1998

Sellaphora tau (Cleve) Metzeltin et Lange-Bert. 1998

Sellaphora tenerrima Metzeltin et LANGE-Bert. 1998

Sellaphora triundulata Metzeltin et LANGE-Bert. 1998

Sellaphora tumida VAN DE VIJVER et BEyENS in VAN DE VIJVER et al. 2002

Sellaphora uruguayensis Metzeltin, Lange-Bert. et García-Rodríguez 2005

Sellaphora ventraloconfusa (LANGe-Bert.) Metzeltin et LANGE-BERT. 1998 'pupula' group

'pupula' group

'pupula' group

'pupula' group

probably 'laevissima' group

'bacillum' group

'bacillum' group?

'pupula' group

'bacillum' group

insufficient data

'pupula' group

'bacillum' group

'pupula' group

insufficient data: 'seminulum' group?

'seminulum' group

insufficient data: 'seminulum' group?

'bacillum' group

'bacillum' group

'pupula' group

'pupula' group

'pupula' group

'bacillum' group

'pupula' group

insufficient data: 'seminulum' group?

'americana' group

insufficient data: 'seminulum' group? 
Table 2 Cont

Sellaphora verecundiae LANGE-BERT. in LANGE-BERT. \& Gerd Moser 1994

Sellaphora vitabunda (Hust.) D.G. MANN 1989

Sellaphora wetzelii (Hust.) Metzeltin et Lange-Bert. 2007

Sellaphora wummensis J.R. JOHANSEN in J.R. JOHANSEN et al. 2004 insufficient data: 'seminulum' group?

'seminulum' group

'bacillum' group

'pupula' group
1950, Round 1957, 1960). However, molecular data show not only (1) that the 'capitata' morphology refers to several different species, rather than one minor infraspecific entity of doubtful status [Krammer \& Lange-Bertalot (1986) abandoned capitata altogether and the form category is used to refer to sporadically occurring variants differing in only one or a few characters: see e.g. STACE (1989)], but also (2) that the segregate species do not constitute a monophyletic group (Evans et al. 2007, 2008).

Thus, the traditional taxonomic interpretation of morphological variation among the larger Sellaphora is faulty. Close examination will probably demonstrate that at least some of the new groupings revealed by molecular analysis possess synapomorphies in aspects of frustule morphology and structure, but at the moment these are not obvious. In the present paper, therefore, we will use the old 'species' of Sellaphora (americana, bacillum, pupula and laevissima) as a framework for documenting diversity because, even though they may not be natural groups, they are familiar and recognizable. Within each of the four, we group demes by overall valve shape and pattern, via a subjective, largely intuitive assessment. The characteristics of the four groups can be summarized thus:

1. 'americana' group (Fig. 1a): axial area wide, central area well-defined and \pm circular, central nodule well-defined (by external grooves enclosing the raphe system), polar bars absent.

2. 'bacillum' group (Fig. 1d): axial area narrow, central area well-defined and \pm circular, central nodule well-defined (by external grooves enclosing the raphe system), polar bars present.

3. 'pupula' group (Fig. 1e): axial area narrow, central area variable (but almost never circular) and well- or poorly defined, central nodule not obvious, polar bars present.

4. 'laevissima' group (Fig. 1b): axial area narrow, central area variable and well- or poorly defined, central nodule often welldefined (by external grooves enclosing the raphe system), polar bars absent.

The only deme discussed here that is difficult to place in one of the four groups is the 'lordly' phenodeme (Fig. 12), which has a transversely rectangular central area as in 'pupula' demes, but a welldefined central nodule as in 'bacillum' demes.

Molecular and cytological data (Mann 1989a, Behnke et al. 2004, Evans et al. 2008) show that, besides the four sets of demes just described, Sellaphora also contains several smallcelled species, such as $S$. seminulum, $S$. disjuncta and the diatom commonly referred to as 'Navicula minima' (Fig. 1c). These also occur in the British Isles (Hartley 1986) but the current study was restricted to the larger Sellaphora species (attaining lengths $>20 \mu \mathrm{m})$.

\section{Material and Methods}

Sampling, specimen preparation and microscopy: The samples examined were derived mostly from our own collections made during the last 30 years (Table 3 ). They were selected to cover a wide variety of lake types, from large pristine oligotrophic lakes (e.g. Loch Maree), through large eutrophic lakes (e.g. Loch Leven), to smaller lowland lakes (e.g. the Shropshire and Cheshire meres) and urban ponds (e.g. the Edinburgh lochs) (broad surveys of the trophic status of the larger British lakes are available to guide choice, e.g. PALMER $\&$ Roy 2001). The aim was to discover as wide a range of variation as possible among the larger Sellaphora species. With the exception of the diatomites from $\mathrm{N}$ Ireland and a squeezing from an Acrocladium carpet, all samples were of epipelon.

To obtain epipelon, a slurry of sediment and overlying water was collected from $30-100 \mathrm{~cm}$ depth by using a glass tube as described by Round (1953). For fine sediments, a litre of slurry was enough, where- 

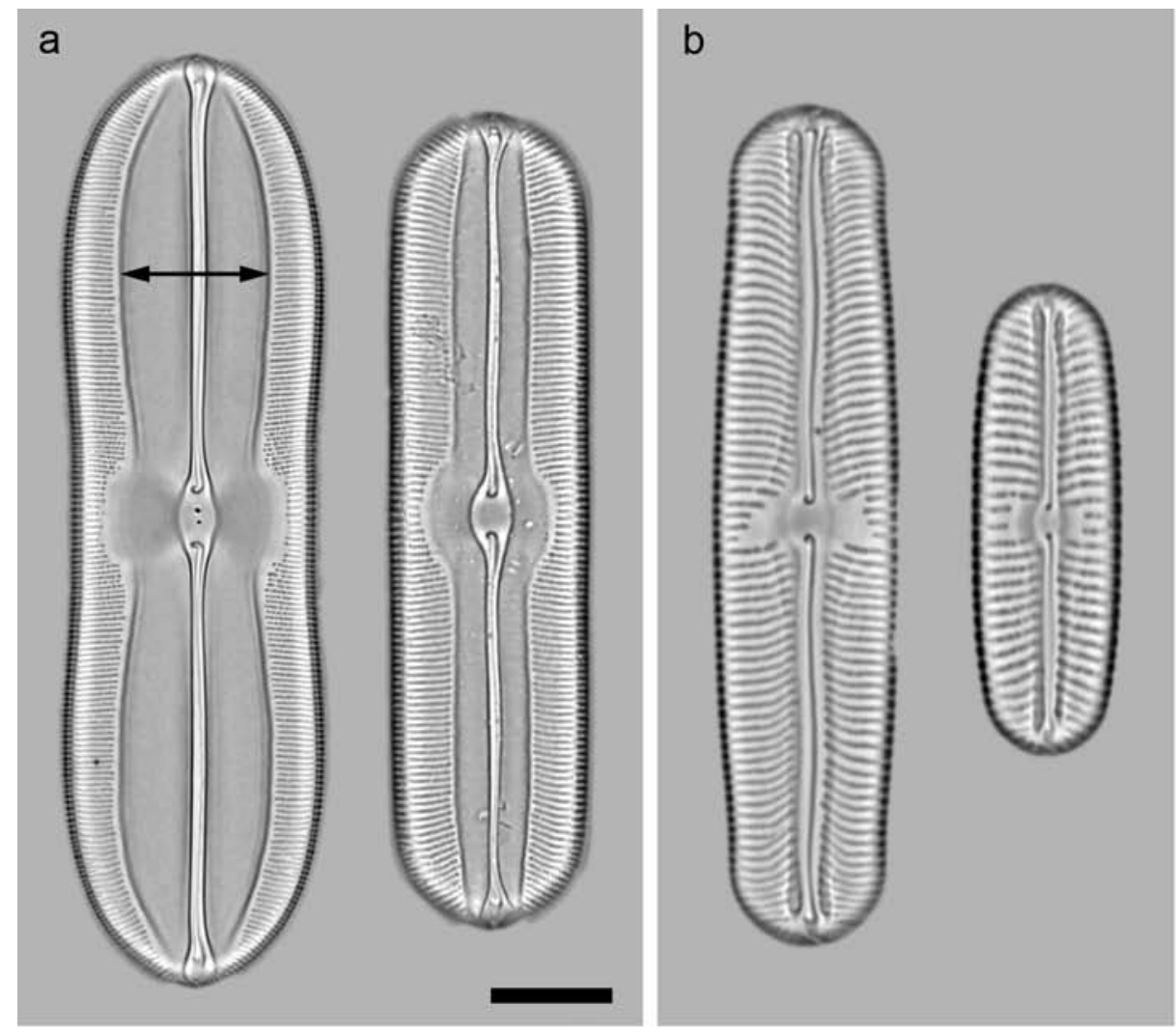

C
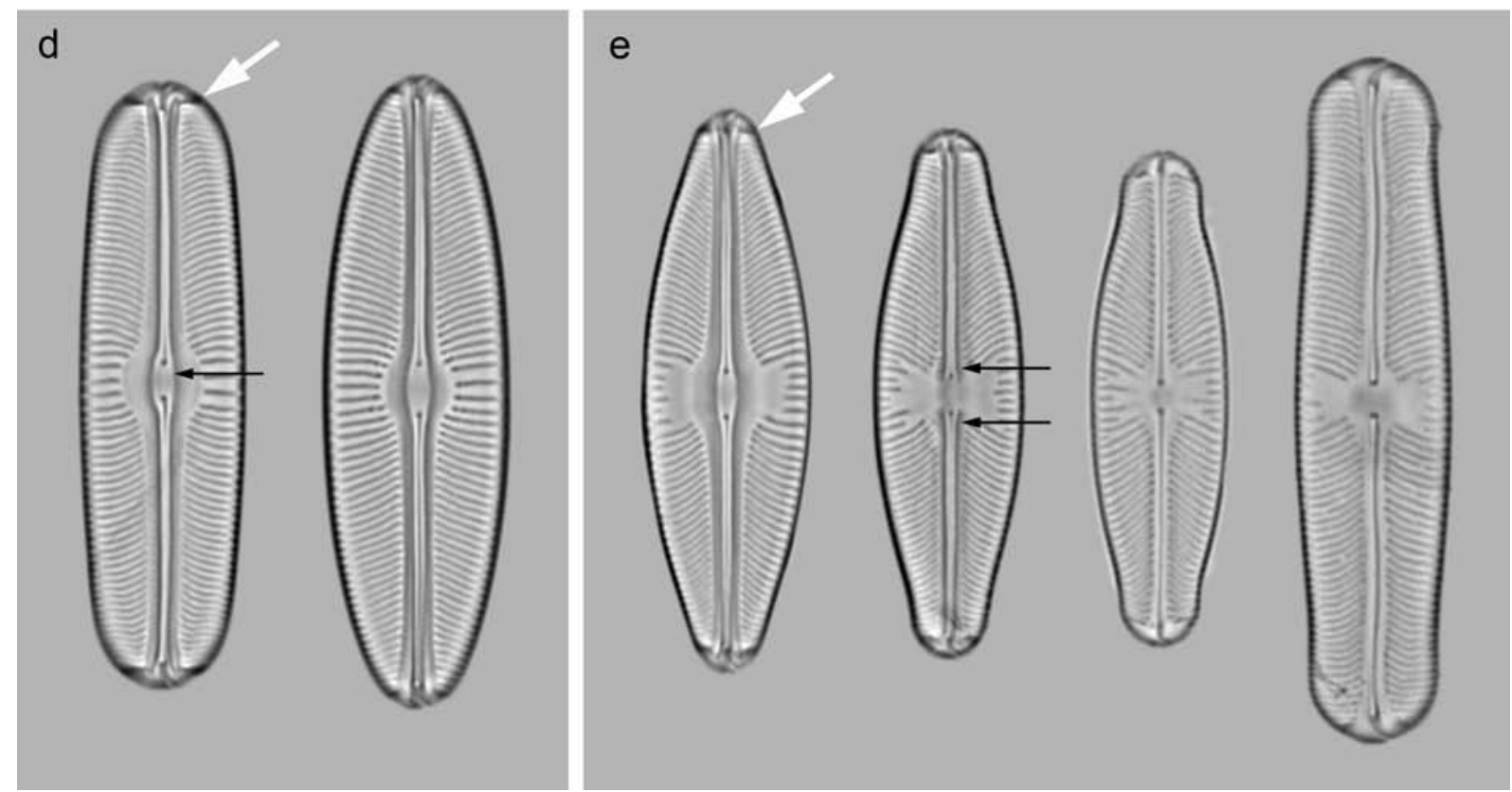

Fig. 1. Deme groupings used in the catalogue of Sellaphora demes: (a) 'americana' group: note the wide axial area (arrow) and distinct central nodule; (b) 'laevissima' group; (c) 'seminulum' group; (d) 'bacillum' group: note the polar bars (e.g. white arrow), the well-defined central area, and the presence of grooves alongside the raphe, which are continuous across the centre (black arrow, defining a small but very distinct elliptical or lanceolate central nodule enclosing the raphe endings); (e) 'pupula' group: note the polar bars (e.g. white arrow) and the variable, transversely elongate central area. Conopeal grooves are sometimes present alongside the raphe (left-hand two valves) but if so, they are usually not continuous across the centre (black arrows); the single exception is the 'lordly' deme (left-most valve). Scale bars $=10 \mu \mathrm{m}$ [for all except the 'americana' group, see the scale bar in (c)]. 
as two litres were generally collected for sand. The slurry was transported to the laboratory in polyethylene bottles, poured out into plastic boxes, and usually allowed to stand in the dark for at least $5 \mathrm{~h}$. Then the supernatant was removed by suction and the sediment covered with lens tissue. Under low illumination (c. 5 $\mu \mathrm{mol}$.photons $\mathrm{m}^{-2} \cdot \mathrm{s}^{-1}$ ), epipelic algae moved up into the lens tissue and could be harvested either by removing this layer of lens tissue or by placing a further layer of lens tissue on the first. The diatoms were extracted by digesting the tissue in boiling acid, either $70 \% \mathrm{HNO}_{3}$ or approximately equal volumes of $70 \% \mathrm{HNO}_{3}$ and $98 \% \mathrm{H}_{2} \mathrm{SO}_{4}$. After washing repeatedly with deionized water to remove unused acid and decomposition products (separation of diatoms from the supernatant was achieved by sedimentation for at least $6 \mathrm{~h}$ in a $4-6 \mathrm{~cm}$ column), $0.5 \mathrm{ml}$ aliquots of suspension were dried onto 18-mm diameter No. 0 cover-slips and mounted in Naphrax (currently available from Brunel Microscopes: http:/www.brunelmicroscopes.co.uk/). The slides used (Table 3) are kept in the diatom herbarium of the Royal Botanic Garden Edinburgh. For observations of living cells (to check protoplast characters), $24 \times 50$ mm cover-slips were placed on top of the lens tissue, removed after a few hours, mounted on drops of WC medium (GUILLARD \& LORENZEN 1972), and ringed with white vaseline to prevent evaporation. These preparations remained healthy for hours, sometimes days.

Several Holocene diatomites were studied from the River Bann area of N Ireland (PLUNKETT et al. 2004), since this was the only British or Irish material known to us in which S. americana had been recorded. Prepared slides were provided by D.H. Jewson and N.G. Cameron.

Bright field (BF) and differential interference contrast (DIC) light microscopy (LM: planapochromat lenses, nominal numerical aperture 1.32) were carried out using a Reichert Polyvar 2 photomicroscope fitted with a Polaroid DMC2 digital camera capable of 1600 $\times 1200$ pixel resolution; images were captured via Optimas image analysis software version 6.2 (Media Cybernetics, Silver Spring, MD 20910, USA). In order to achieve a satisfactory pixel density in the final image, we used the $1.25 \times$ intermediate lens of the Polyvar, except for $S$. americana where cells were so large that we had to use the $0.8 \times$ lens. Background specks were removed digitally by image division (BAYER et al. 2001; http://rbg-web2.rbge.org.uk/algae/microscopy_removing_dust.html). Since many phycologists and ecologists do not have microscopes fitted with DIC optics, we used BF microscopy to construct the atlas of Sellaphora. This also provided good and uniform definition of the valve outline. The maximum resolution possible with a non-immersed condenser was achieved by strict use of Köhler illumination, with the condenser diaphragm set just outside the aperture-limiting diameter.

In diffraction-limited BF systems, two equal and opposite images are formed of small transparent objects (which become visible only through differences in refractive index between object and mountant) or small holes. One image is dark against the background (the 'black-spot focus'), the other light against the background (the 'white-spot focus'). Neither focus is 'correct' (Houk's 2003 otherwise helpful guidance on imaging is misleading on this point) and when the object or hole is exactly in the image plane, it is invisible (see Mann et al. 2007). The relative vertical positions of the black- and white-spot focuses in BF systems depend on whether the object has a higher or lower refractive index than the mountant, and phase contrast optics produce three in-focus images, one of opposite phase to the other two (MANN et al. 2007). The valves of Sellaphora species are of only modest depth (c. 2-5 $\mu \mathrm{m})$, but this is still much greater than the depth-offocus at a numerical aperture of 1.32. It is therefore impossible to capture a single image in which the valve face and margin are both in focus. One solution to this is to make extended-depth-of-focus images from image stacks through use of one of the many algorithms currently available (e.g. in ImageJ at http://rsb.info.nih. gov/ij/; see also MANN et al. 2006); another is to make the image stack directly available as a digital video (for example, videos and 'focusable' image stacks of the lectotype and an epitype of $S$. pupula are available at http://rbg-web2.rbge.org.uk/algae/research/types/ Sellaphora_pupula_type.html). In the current study, however, we used a single best-compromise image of each specimen. For this, we selected only those specimens whose valve face lay uppermost and focused the raphe and striae in black-spot focus; this lies below the white-spot focus in specimens mounted in Naphrax and hence gave better though still imperfect definition of the valve margin.

Digital images were taken at a resolution of 26.5 pixels : $1 \mu \mathrm{m}$ and prepared for publication by global application of the Levels and Brightness/Contrast functions in Adobe Photoshop (www.adobe.com) and resizing through bicubic resampling to achieve a magnification of $\times 2000$ on the printed page. Recently, most micrographs (e.g. in Krammer \& LANGe-Bertalot 1986 or the Iconographia diatomologica series) have been printed at $\times 1500$ but this is rather low for diatoms with fine striation of 20 in $10 \mu \mathrm{m}$ or more: the choice of $\times 2000$ makes our micrographs directly comparable with those of SiMONSEN (1987) or SCHOEMAN \& ARCHIBALD (1976-1980). Modest image enhancement was achieved through use of the Adobe Unsharp Mask tool on the resized images at $60 \%$, with 3.5 pixel radius. The original photographs were of various sizes and aspect ratios but were made up to a standard size for each deme by filling gaps with the average background grey level. No attempt was made to extract a diatom from its background, although this can be highly effective (BAYER et al. 2001). Rarely, a High Pass filter (radius 12 pixels) was applied to improve image quality in cases where the specimen was a theca or frustule (with 
Table 3. List of samples studied: details of the localities are held in the Royal Botanic Garden, Edinburgh (RBGE). Most slides examined are part of the unified RBGE series (prefix 'E'). Others came from non-incorporated sets of slides from Blackford Pond and Threipmuir, and the remainder were from the Bernard Hartley (BH) slide collection at RBGE.

\begin{tabular}{|c|c|c|c|}
\hline Site & $\begin{array}{l}\text { Administrative } \\
\text { district, Country }\end{array}$ & Collector(s) & Slides examined \\
\hline Ballyscullion diatomite & $\begin{array}{l}\text { Co Londonderry, } \mathrm{N} \\
\text { Ireland }\end{array}$ & $\begin{array}{l}\text { T. Gibson Ltd, } \\
\text { Dundonald }\end{array}$ & $\begin{array}{l}\text { BH411A '(large), July } \\
1972 \text { ' }\end{array}$ \\
\hline Portglenone diatomite & Co Antrim, N Ireland & $\begin{array}{l}\text { D. Jewson \& N. } \\
\text { Cameron }\end{array}$ & E3557 \\
\hline Toomebridge diatomite & Co Antrim, N Ireland & $\begin{array}{l}\text { D. Jewson \& N. } \\
\text { Cameron /R.I. Firth }\end{array}$ & $\begin{array}{l}\text { E3547, BH314A } \\
\text { '(Pleurax 2) November } \\
\text { 1976', BH344 '>600 } \\
\text { mesh Sept 1971', } \\
\text { BH344 'Hyrax, August } \\
\text { 1986' }\end{array}$ \\
\hline Loch Maree & Highland, Scotland & $\begin{array}{l}\text { W. Marshall, D.G. } \\
\text { Mann \& S.J.M. Droop }\end{array}$ & E2749.1, E2763.1 \\
\hline Loch Tulla & Argyll \& Bute, Scotland & $\begin{array}{l}\text { D.G. Mann \& A.J. } \\
\text { Stickle, D.G. Mann }\end{array}$ & E297, E3747/2 \\
\hline Loch Lubnaig & Stirling, Scotland & $\begin{array}{l}\text { D.G. Mann \& A. } \\
\text { Poulíčková }\end{array}$ & $\mathrm{E} 3580 / 2$ \\
\hline Loch Venachar & Stirling, Scotland & $\begin{array}{l}\text { D.G. Mann \& A. } \\
\text { Poulíčková }\end{array}$ & E3584/3 \\
\hline Loch Voil & Stirling, Scotland & $\begin{array}{l}\text { D.G. Mann \& A. } \\
\text { Poulíčková }\end{array}$ & E3582/1 \\
\hline Loch Achray & Stirling, Scotland & $\begin{array}{l}\text { D.G. Mann \& A. } \\
\text { Poulíčková }\end{array}$ & E3585/1 \\
\hline Lake of Menteith & Stirling, Scotland & $\begin{array}{l}\text { D.G. Mann \& A. } \\
\text { Poulíčková }\end{array}$ & E3588/2 \\
\hline Balgavies Loch & Angus, Scotland & D.G. Mann & E2619/1 \\
\hline Loch of Craiglush & $\begin{array}{l}\text { Perth \& Kinross, } \\
\text { Scotland }\end{array}$ & $\begin{array}{l}\text { D.G. Mann \& A.J. } \\
\text { Stickle }\end{array}$ & E323/2 \\
\hline Loch of Butterstone & $\begin{array}{l}\text { Perth \& Kinross, } \\
\text { Scotland }\end{array}$ & $\begin{array}{l}\text { D.G. Mann \& A.J. } \\
\text { Stickle, D.G. Mann \& } \\
\text { A. Poulíčková }\end{array}$ & E327/3, E3673/1 \\
\hline Loch of Drumellie & $\begin{array}{l}\text { Perth \& Kinross, } \\
\text { Scotland }\end{array}$ & $\begin{array}{l}\text { D.G. Mann \& A.J. } \\
\text { Stickle }\end{array}$ & E329/2 \\
\hline Loch of Clunie & $\begin{array}{l}\text { Perth \& Kinross, } \\
\text { Scotland }\end{array}$ & $\begin{array}{l}\text { D.G. Mann \& A.J. } \\
\text { Stickle, D.G. Mann \& } \\
\text { A. Poulíčková }\end{array}$ & $\mathrm{E} 328 / 3, \mathrm{E} 3671 / 2$ \\
\hline Rae Loch & $\begin{array}{l}\text { Perth \& Kinross, } \\
\text { Scotland }\end{array}$ & $\begin{array}{l}\text { D.G. Mann \& A. } \\
\text { Poulíčková }\end{array}$ & E3672/1 \\
\hline Fingask Loch & $\begin{array}{l}\text { Perth \& Kinross, } \\
\text { Scotland }\end{array}$ & $\begin{array}{l}\text { D.G. Mann \& A.J. } \\
\text { Stickle }\end{array}$ & E331/2 \\
\hline Monk Myre & $\begin{array}{l}\text { Perth \& Kinross, } \\
\text { Scotland }\end{array}$ & $\begin{array}{l}\text { D.G. Mann \& A.J. } \\
\text { Stickle }\end{array}$ & E332/2 \\
\hline
\end{tabular}




\begin{tabular}{|c|c|c|c|}
\hline Loch Leven & $\begin{array}{l}\text { Perth \& Kinross, } \\
\text { Scotland }\end{array}$ & $\begin{array}{l}\text { D.G. Mann, A. } \\
\text { Poulíčková, E. Jamieson } \\
\text { \& B. Spears }\end{array}$ & $\begin{array}{l}\mathrm{E} 3690 / 3, \mathrm{E} 3830 / 1 \\
\mathrm{E} 3830 / 3, \mathrm{E} 3830 / 6, \\
\mathrm{E} 3832 / 3, \mathrm{E} 3832 / 4\end{array}$ \\
\hline Blackford Pond & $\begin{array}{l}\text { City of Edinburgh, } \\
\text { Scotland }\end{array}$ & D.G. Mann & $\begin{array}{l}\text { E16/3, E16 'Stand', } \\
\text { E3578/1, E3667/2, } \\
\text { 'Blackford Pond } \\
\text { 18.12.86 thin 1' }\end{array}$ \\
\hline Dunsapie Loch & $\begin{array}{l}\text { City of Edinburgh, } \\
\text { Scotland }\end{array}$ & D.G. Mann & $\begin{array}{l}\mathrm{E} 3572, \mathrm{E} 4109 / 2, \\
\text { '18.4.88/1' }\end{array}$ \\
\hline Lochend Loch & $\begin{array}{l}\text { City of Edinburgh, } \\
\text { Scotland }\end{array}$ & $\begin{array}{l}\text { D.G. Mann, K.M. Evans } \\
\text { \& A. Prendergast }\end{array}$ & $\mathrm{E} 3752 / 2$ \\
\hline Inverleith Pond & $\begin{array}{l}\text { City of Edinburgh, } \\
\text { Scotland }\end{array}$ & D.G. Mann & E319/2 \\
\hline $\begin{array}{l}\text { Royal Botanic Garden } \\
\text { Pond }\end{array}$ & $\begin{array}{l}\text { City of Edinburgh, } \\
\text { Scotland }\end{array}$ & $\begin{array}{l}\text { D.G. Mann, D.G. Mann } \\
\text { \& A. Poulíčková }\end{array}$ & $\begin{array}{l}\text { E2614/2, E2614/3, } \\
\text { E3699/2 }\end{array}$ \\
\hline $\begin{array}{l}\text { Mire, NE of Threipmuir } \\
\text { Reservoir }\end{array}$ & $\begin{array}{l}\text { City of Edinburgh, } \\
\text { Scotland }\end{array}$ & D.G. Mann & $\begin{array}{l}\text { 'NE Threipmuir } \\
\text { Acrocladium ... sample } \\
7,2.4 .81 \text {, slide 2' }\end{array}$ \\
\hline Threipmuir Reservoir & $\begin{array}{l}\text { City of Edinburgh, } \\
\text { Scotland }\end{array}$ & D.G. Mann & $\begin{array}{l}\text { E2588/3, 'Threipmuir } \\
\text { Marsh Basin usual } \\
\text { 11.6.86 B (thin)', } \\
\text { 'Threipmuir NE Basin } \\
\text { sandy ... 11.6.86 A', } \\
\text { 'Threipmuir Middle } \\
\text { Basin NW end/ } \\
\text { coffer dam 11.6.86 } \\
\text { C', 'Threipmuir usual } \\
\text { 29.9.86 B', Threipmuir } \\
\text { Reservoir1 11.10.05a }\end{array}$ \\
\hline Lindean Reservoir & $\begin{array}{l}\text { Scottish Borders, } \\
\text { Scotland }\end{array}$ & A.J. Stickle & E88 'sonic' \\
\hline Heart Moss, mire pools & $\begin{array}{l}\text { Dumfries \& Galloway, } \\
\text { Scotland }\end{array}$ & D.G. Mann & $\mathrm{E} 423 / 1, \mathrm{E} 424 / 2$ \\
\hline Whinfell Tarn & Cumbria, England & A.J. Stickle & E53 \\
\hline Little Water & Cumbria, England & K. Atkinson & 'B' \\
\hline Priest Pot & Cumbria, England & $\begin{array}{l}\text { D.G. Mann \& A. } \\
\text { Poulíčková }\end{array}$ & E3683/1, E3683/2 \\
\hline Malham Tarn & $\begin{array}{l}\text { North Yorkshire, } \\
\text { England }\end{array}$ & $\begin{array}{l}\text { D.G. Mann \& A. } \\
\text { Poulíčková }\end{array}$ & $\mathrm{E} 3685 / 3, \mathrm{E} 3686 / 3$ \\
\hline Budworth Mere & Cheshire, England & $\begin{array}{l}\text { D.G. Mann \& A.J. } \\
\text { Stickle }\end{array}$ & E342/2 \\
\hline Pick Mere & Cheshire, England & $\begin{array}{l}\text { D.G. Mann \& A.J. } \\
\text { Stickle }\end{array}$ & E341/1 \\
\hline Cole Mere & Shropshire, England & $\begin{array}{l}\text { D.G. Mann \& A.J. } \\
\text { Stickle }\end{array}$ & E339/3 \\
\hline Crose Mere & Shropshire, England & $\begin{array}{l}\text { D.G. Mann \& A.J. } \\
\text { Stickle }\end{array}$ & E336/3 \\
\hline
\end{tabular}




\begin{tabular}{|c|c|c|c|}
\hline Ellesmere & Shropshire, England & $\begin{array}{l}\text { D.G. Mann \& A.J. } \\
\text { Stickle }\end{array}$ & E335/3 \\
\hline Hanmer Mere & Shropshire, England & $\begin{array}{l}\text { D.G. Mann \& A.J. } \\
\text { Stickle }\end{array}$ & E334/3 \\
\hline Oss Mere & Shropshire, England & $\begin{array}{l}\text { D.G. Mann \& A. } \\
\text { Poulíčková }\end{array}$ & E3590/2 \\
\hline White Mere & Shropshire, England & $\begin{array}{l}\text { D.G. Mann \& A.J. } \\
\text { Stickle }\end{array}$ & E338/3 \\
\hline $\begin{array}{l}\text { Kates Cottage Pond, } \\
\text { Sturston }\end{array}$ & Norfolk, England & K. Clarke & '8 Aug 86' \\
\hline Burton Pond, Petworth & West Sussex, England & R.I. Firth & $\begin{array}{l}\text { BH } 250 \text { '19 January } \\
1971 \text { August } 1986 \text { A', } \\
\text { BH } 250 \text { '19.2.71 March } \\
1971 \text { B' }\end{array}$ \\
\hline
\end{tabular}

strong haloes around its edges) or was partly overlain by girdle bands.

All valves shown in Figs 3-56 are presented in the same orientation, with the primary side of the valve (Round et al. 1990, pp. 40-42) to the left.

Survey strategy: For each lake chosen for analysis, we scanned slides at low magnification to determine whether any Sellaphora species were present, belonging to the 'pupula', 'bacillum', 'laevissima' and 'americana' groups. If any were seen, we methodically surveyed Sellaphora diversity on the slide under $a \times$ 100 oil immersion lens, along \pm contiguous transects. All non-obscured valves were photographed until we judged that taking further photographs would not be cost-effective (in the context of an alpha-taxonomic survey) in increasing the number of demes recorded for that site, or in increasing our understanding of variation within each deme. The proportion of a slide studied in this way varied with the density of the preparation and the proportion of the flora contributed by Sellaphora species, which was rarely more than $10 \%$ of the total flora and sometimes below $0.1 \%$. Where non-obscured valves were unavailable, we photographed thecae, complete frustules or partly obscured specimens.

Collection of images and image data was facilitated by use of a Macro written within Optimas by S.J.M. Droop, which prompted for slide identity, specimen location (recorded via the microscope stage coordinates), essential image data (magnification, optics, filename), and a preliminary identification of the specimen. These were written to an Excel spreadsheet. Thus a first estimate of diversity and deme identities was made while we were surveying a slide and this guided the selection of specimens to be photographed. Subsequently, we sorted the digital images from a particular location by eye, grouping them into series that could be interpreted as stages in size reduction. In this, we were guided by previous work on Sellaphora (MANN 1984, 1988a, 1989a, b, MANN et al. 1999, 2004) and other pennate diatoms (notably GeITLER 1932). This process created groups that can be called 'phenotopodemes' in the terminology of GILMOUR \& HESLOP-HARRISON (1954), i.e. demes of Sellaphora occurring in a specified geographical area (here, usually a single lake) and differing phenotypically from other demes of Sellaphora occurring in the same area. We then examined all the series from all localities to establish which of them might be considered essentially identical (again, a subjective decision), so that we could construct geographically unrestricted 'phenodemes'. During this second sorting, we were guided not only by previous information about the life cycle and intraclonal variation in Sellaphora but also by our discovery (MANN 1984, 1988a, 1989b, MANn et al. 1999, 2004, BEHNKE et al. 2004, EvANs et al. 2007, 2008) that what appear to be very small, though consistent, morphological differences can be correlated with significant molecular genetic divergence or sexual incompatibility (cf. MANN \& Chepurnov 2005, Sarno et al. 2005, Trobajo et al. 2006, Амато et al. 2007). It should not be assumed that we regard the phenodemes as equivalent to any particular taxonomic category, nor that they are equivalent to each other in terms of how distinct they are or how much variation they encompass.

Finally, each phenodeme was assigned an informal name based on appearance, a source locality, or idiosyncratic associations. The purpose of the informal names was simply to aid memory and communication. The naming convention we adopted for this paper was that suggested in a report by MANN \& KocioleK (1990): for example, the name "Sellaphora [pupula $\mathrm{K}-\mathrm{LB}] \Phi$ 'tidy" means a phenodeme $(\Phi)$ called 'tidy' that would be classified in Sellaphora pupula as defined by KRAMMER \& LANGE-BERTALOT (1986), which we use here as the 'standard' diatom flora for the region. 
Our activities deliberately mimicked what an angiosperm taxonomist does during a herbarium-based investigation. The first step is to obtain flowering specimens from nature, which are not a random sample of all available material but a modest selection of specimens thought to represent diversity adequately: expert knowledge (which of course is not infallible) is used in the field to assess the significance of apparent discontinuities in the pattern of variation within and among populations of a higher taxon (here, Sellaphora) and thus to define an absolute minimum of 'collection-worthy entities' that must be sampled and recorded. This phase is equivalent to our choice of diatom specimens for digital imaging. Once collected, the specimens (here, images) are sorted in the herbarium by visual comparison, again guided by expert knowledge (e.g. of the life cycle) and also by detailed examination of any special features (e.g. the presence or absence of grooves alongside the raphe system, or the striation pattern) and measurements (stria density and valve dimensions), to create 'operational taxonomic units' (OTUs). After further study and refinement, OTUs are often recognized formally as taxa, but we avoid this here, for reasons discussed later.

For this survey, we took digital photographs of over 3200 Sellaphora specimens from natural populations, supplemented by over 900 images of specimens from clonal cultures (not shown here). The photographs used in Figs 3-56 were selected to illustrate size reduction and variation, but in some cases (e.g. $S$. blackfordensis and S. capitata) we restricted the range shown in order to facilitate comparison with similar demes (in this case, $\Phi$ 'pseudocapitate', $\Phi$ 'cf. capitate' and $\Phi$ 'caput'). All of the original photographs have been retained and can be made available for consultation on application to the authors.

Measurements and terminology: Shape was assessed by reference to BARBER \& HAWORTH (1981), in order to standardize descriptions. The length and width ranges refer to those specimens photographed during this study. Experience shows that the longest cells of a species are almost always rare in natural populations and there seem to be good population biological reasons why this is so (MANN 1988b, MANN et al. 1999). Thus, the observed range of size, even in a large sample, is almost always less than the total range exhibited during the life cycle. Nevertheless, incomplete observed ranges can still be helpful in identification, because they are representative of what is usually found in nature. Valve width, which varies much less than valve length both absolutely and relatively (GEITLER 1932), is a particularly useful character in pennate diatoms. For the six species described in detail by MANN et al. (2004), the ranges reported in 2004 are generally wider than those included here because (1) even more specimens were examined than was practical during our current analysis, and (2) MANN et al. (2004) were able to ob- serve auxosporulation in several cases. In order to provide roughly comparable data for all demes, we have distinguished between the older and current data-sets by putting the older ones in parentheses, where they exceed the range recorded here.

Stria densities were measured parallel to and near the raphe-sternum on the primary side of the valve, by determining the distance occupied by 10 striae starting from the first complete stria out from the central area; this was done in Photoshop by using the ruler calibrated in pixels. Two measurements were made for each valve and the descriptions give the minimum, average, and maximum for the valves illustrated; again, where previous data (MANN et al. 2004) give a wider range, this is indicated. Stria and polar bar orientations are described as parallel, radiate and convergent, in accordance with the illustrations of BARBER \& HAWORTH (1981, fig. 8B).

Some characters seemed to vary continuously among the demes studied and we made arbitrary decisions about character state boundaries, for example between 'strongly sinuous' and 'sinuous' raphe slits, or between 'strongly expanded' and 'expanded' central areas. We suspect that the raphe slits are never perfectly straight, but in the light microscope some Sellapho$r a$ raphes are very obviously sinuous while others are not (e.g. Fig. 1). The polar bars of $S$. bacillum and $S$. pupula replace one or two striae and interstriae and run parallel to the adjacent striae. Hence we describe their declination using the three terms used for stria patterns - parallel, radiate or convergent (BARBER \& HAWORTH 1981).

Many Sellaphora species are grooved externally alongside the raphe and these are sometimes covered by conopea to form canals, as shown by SIMS \& PADDOCK (1979), MANN (1989a) and Round et al. (1990). In LM it is often possible to detect the presence of conopea, but we were not always able to distinguish between simple grooves (such as occur in some 'laevissima' demes) and grooves covered by conopea (as in the 'americana' and 'bacillum' demes, and in some 'pupula' demes such as 'small lanceolate').

In most Sellaphora species, the areolae are invisible in LM and the striae therefore appear as simple lines. However, the striae are clearly punctate in some demes, e.g. the 'elliptical' demes of $S$. [pupula], and in $S$. lanceolata and some other $S$. [pupula] demes the longer central striae continue inwards as non-areolate grooves (MANN et al. 2004), which we term 'ghost striae' (Fig. 2).

Comparisons with demes and species recognized elsewhere: We looked for previous records of Sellaphora demes in published papers. Unfortunately, it was often impossible to make meaningful comparisons with our material, because (1) before 1980, records were often not illustrated or they were illustrated with line drawings that cannot be interpreted with confidence, 


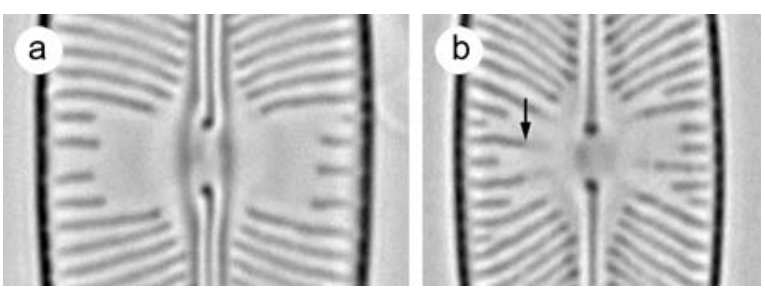

Fig. 2. The central areas of (a) Sellaphora obesa and (b) $S$. lanceolata. In S. lanceolata each longer central stria consists of a marginal part containing areolae, which appears dark like the striae elsewhere on the valve, and a part nearer the raphe that appears paler because it does not contain areolae (although it is thinner than the interstriae); the arrow indicates the junction between these two sectors for one such stria. By contrast, $S$. obesa has simple striae.

(2) many photographs are of such poor quality that the subtleties of shape and striation are lost, or (3) only one or a few valves are illustrated per deme, so that life cycle variation could not be judged. By far the best sets of photographs available to us were those of the Iconographia diatomologica series (LANGE-BERTALOT \& Genkal 1999, Lange-Bertalot \& Metzeltin 1996, LANGe-Bertalot et al. 1996, 2003, LeVkov et al. 2007, Metzeltin \& Lange-Bertalot 1998, 2002, 2007, MetZELTin \& WitKowski 1996, Metzeltin et al. 2005, RuMRich et al. 2000, Werum \& Lange-Bertalot 2004). Our 'Remarks' are therefore strongly biased towards these volumes and if it appears that we are biased and have been unfairly critical of them, it is only because they are almost the only works where the illustrations and documentation were good enough to allow us to make a tentative evaluation.

In order to make it easier to test for the existence of similar demes elsewhere, we have provided references to published cox 1 sequences (Evans et al. 2007), which can function as 'DNA BARCODES'. In a few cases, cox 1 sequences are not cited, even though relevant data have been published (Evans et al. 2007). This reflects uncertainty in a few cases that we have correctly linked the cox 1 sequences, which were all obtained from single-cell isolates, to the natural populations used to construct the phenodeme catalogue. We have arranged the phenodemes first by species group ([americana], [bacillum], etc.) and then by our subjective estimate of overall similarity, which we hope places each deme nearest to those with which it might most easily be confused. The aim of the arrangement was to facilitate comparison and identification, not to imply close phylogenetic relationship.

\section{Results}

\section{AMERICANA GROUP Sellaphora [americana K-LB] Ф 'wide' (Fig. 3)}

Valves strictly linear, with broadly and smoothly rounded poles, 54-72 × 15-17 $\mu \mathrm{m}$. Striae parallel or very slightly radiate centrally, becoming more strongly radiate near the poles, $16.7-17.5-18.0$ in $10 \mu \mathrm{m}$; areolae visible in LM. Axial area wide, occupying $>30 \%$ of the valve width, representing a depressed plain area covered by a wide conopeum. Central area well-defined, \pm circular. Raphe-sternum well-defined because of the adjoining depressed plain area, markedly expanded into an elliptical 'central nodule' surrounding the central raphe endings. Raphe sinuous. Polar bars absent.

REMARKs: Apparently the same deme was illustrated by Lange-Bertalot \& Metzeltin (1996, pl. 25, figs 1, 2; see also Metzeltin et al. 2005, pl. 63, fig. 2) from Lake Julma Ölkky, Finland, and by Metzeltin \& LangeBertalot (2002, pl. 31, fig. 7; pl. 70, fig. 1; see also Metzeltin et al. 2005, pl. 63, fig. 1) from a river at Zomandao, Madagascar. All have c. 17 striae in $10 \mu \mathrm{m}$. However, the Madgascan specimens are proportionately slightly wider and the striae appear to be more coarsely punctate.

\section{Sellaphora [americana K-LB] $\Phi$ 'narrow' (Fig. 4)}

Valves linear, with margins very slightly bowed inwards towards the centre and rounded, slightly cuneate poles that are somewhat abruptly set off from the lateral margins, 64-80 × 14-14.5 $\mu \mathrm{m}$. Striae parallel or very slightly radiate centrally, becoming more strongly radiate near the poles, 16.7-17.4-18.0 in $10 \mu \mathrm{m}$; areolae visible in LM. Axial area wide, occupying $>30 \%$ of the valve width, representing a depressed plain area covered by a wide conopeum. Central area well-defined, \pm circular. Raphe-sternum well-defined because of the adjoining depressed plain area, markedly expanded into an elliptical 'central nodule' surrounding the central raphe endings. Raphe sinuous. Polar bars absent.

Remarks: Very similar to $\Phi$ 'wide' but consistently narrower at any given length, despite occurring in the same samples.

\section{BACILLUM GROUP \\ Sellaphora [bacillum K-LB] $\Phi$ 'rectangular' (Fig. 5)}

Valves linear becoming linear-elliptical, with smoothly rounded poles, $21.5-53 \mu \mathrm{m} \times 9.5-10.75$ $\mu \mathrm{m}$. Striae slightly radiate throughout, more widely spaced but with no intercalated striae at the centre, 19.1-21.0-23.7 in $10 \mu \mathrm{m}$; areolae invisible in 


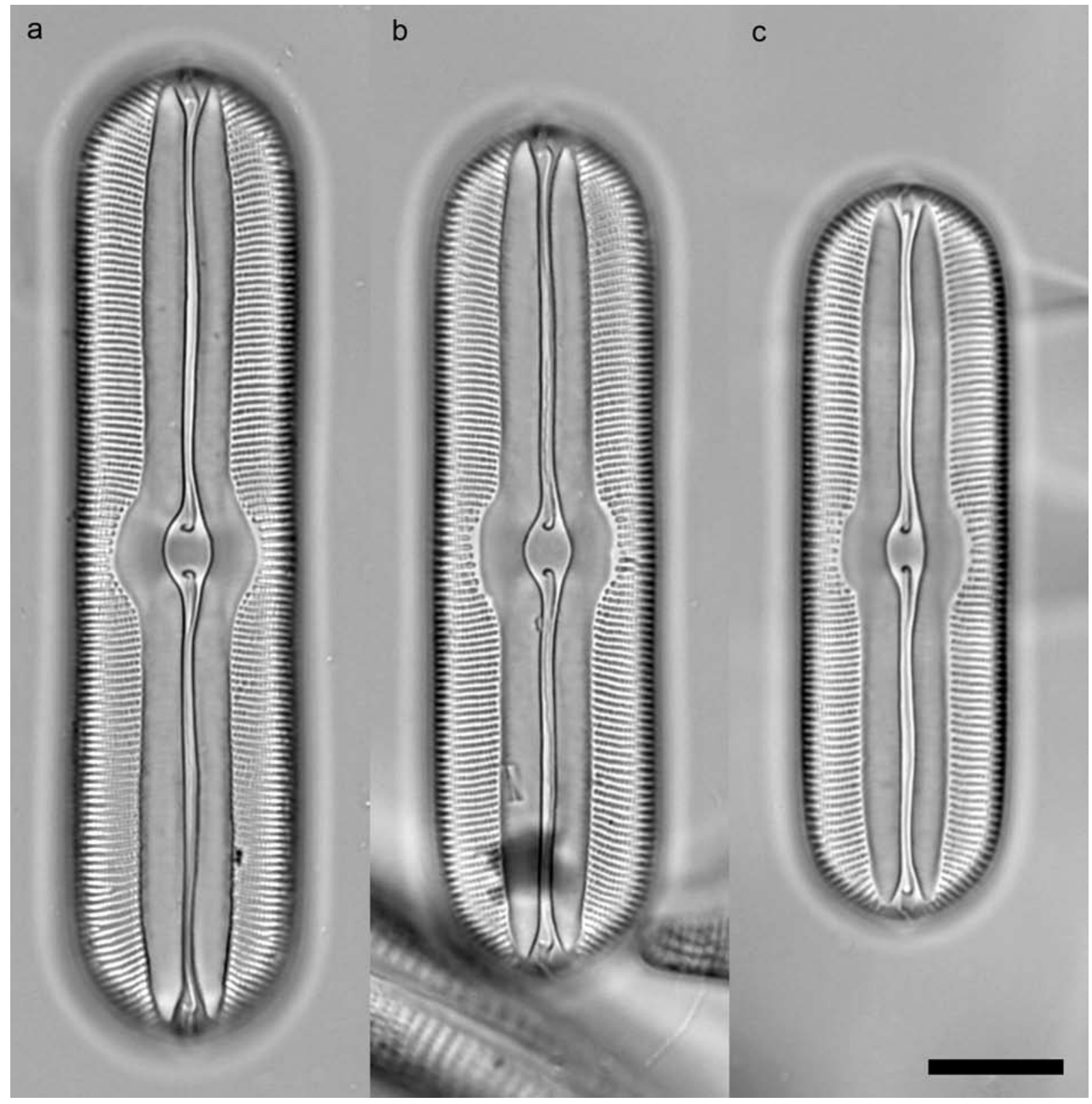

Fig. 3. Sellaphora [americana K-LB] $\Phi$ 'wide': Toomebridge diatomite; (a) slide BH 314A (Pleurax 2), November 1976; (b, c) slide BH 344, Fossil F/W deposit, Hyrax, August 1986. Scale bar $=10 \mu \mathrm{m}$.

LM (except, occasionally, for a few immediately adjacent to the central area). Axial area narrow, occupying c. $20 \%$ of the valve width near the centre, representing a depressed plain area covered by a narrow conopeum. Central area expanded in longer specimens (to $35-45 \%$ of the valve width), merging gradually into the axial area, \pm circular. Raphe-sternum well-defined because of the adjoining depressed area, narrow, expanded into a narrowly elliptical 'central nodule' surrounding the central raphe endings. Raphe very slightly sinuous. Polar bars present, parallel. DNA BARCODE (COX1): GenBank EF164941.

\section{Sellaphora [bacillum K-LB] $\Phi$ 'button' (Fig. 6)}

Valves linear becoming linear-elliptical, with smoothly rounded poles, $23-38 \times 8.75-9.75 \mu \mathrm{m}$. Striae slightly radiate throughout, more widely spaced but with no intercalated striae at the centre, 22.3-22.9-24.1 in $10 \mu \mathrm{m}$; areolae invisible in LM. Axial area narrow, occupying c. $20 \%$ of the valve width near the centre, representing a depressed plain area covered by a narrow conopeum. Central area markedly expanded (to $45-50 \%$ of the valve width), well-defined, \pm circular. Raphesternum well-defined because of the adjoining 


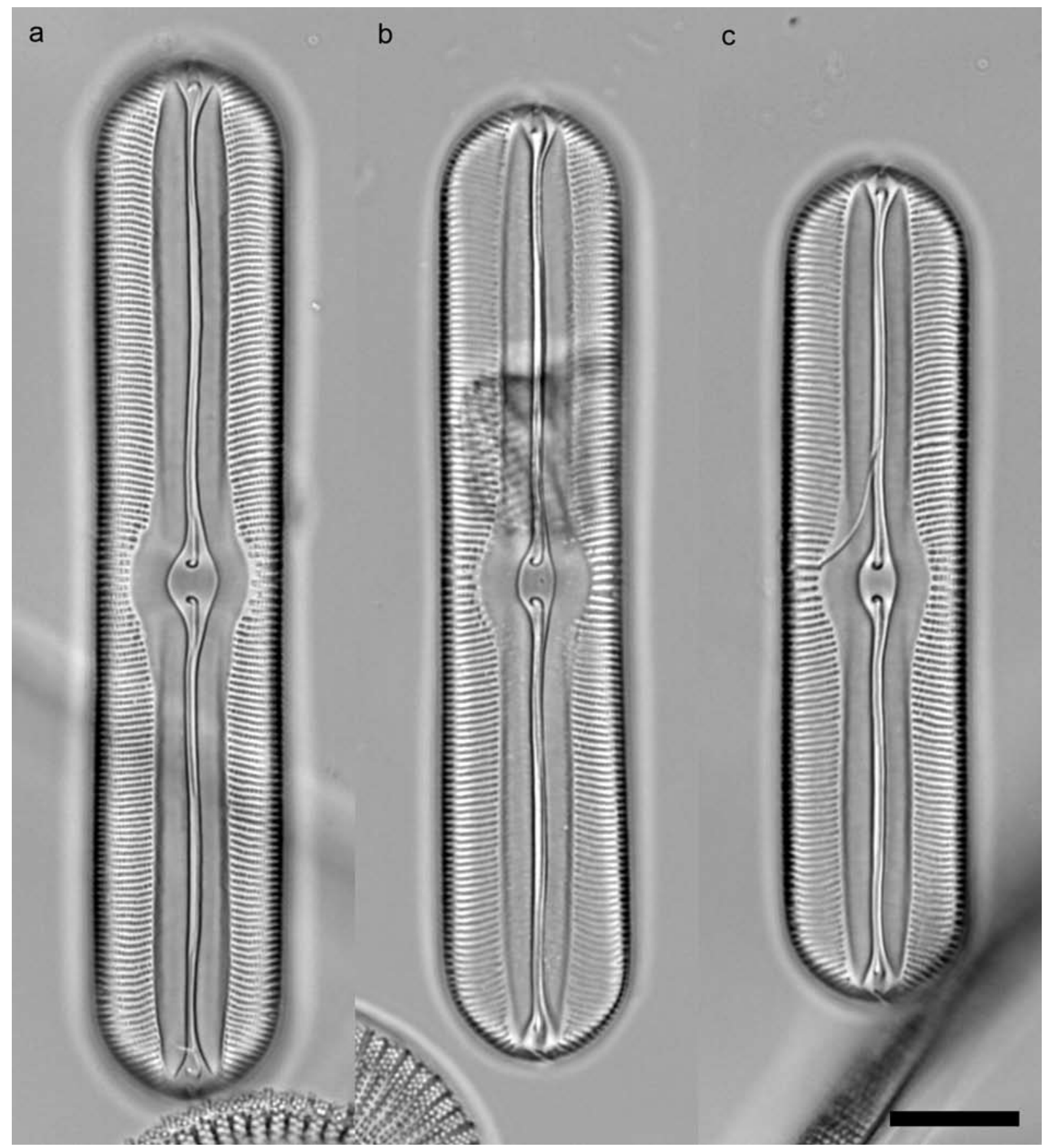

Fig. 4. Sellaphora [americana K-LB] $\Phi$ 'narrow': Toomebridge diatomite; (a, c) slide BH 344, Fossil F/W deposit, Hyrax, August 1986; (b) slide BH 344, >600 mesh, Sept 1971. Scale bar $=10 \mu \mathrm{m}$.

depressed area, narrow, expanded into a narrowly elliptical 'central nodule' surrounding the central raphe endings. Raphe very slightly sinuous. Polar bars present, parallel.

REMARKS: Separated from $\Phi$ 'rectangular' by its narrower and more finely striated valves and the distinctive, button-like, expanded central area.

\section{Sellaphora [bacillum K-LB] $\Phi$ 'oval' (Fig. 7)}

Valves linear-elliptical becoming elliptical, with smoothly rounded poles, $19-38 \mu \mathrm{m} \times 8.75-10.5$ $\mu \mathrm{m}$. Striae slightly radiate throughout, slightly more widely spaced but with no intercalated striae at the centre, $18.3-19.1-20.2$ in $10 \mu \mathrm{m}$; areolae invisible in LM. Axial area narrow, occupying c. $20 \%$ of the valve width near the centre, representing a depressed plain area covered by a narrow conopeum. Central area scarcely expanded (to c. $30 \%$ of the valve width in longer specimens), welldefined, \pm circular. Raphe-sternum well-defined 
because of the adjoining depressed area, narrow, expanded into a narrowly elliptical 'central nodule' surrounding the central raphe endings. Raphe very slightly sinuous. Polar bars present, parallel.

\section{Sellaphora [bacillum K-LB] $\Phi$ 'buttermax'} (Fig. 8)

Valves narrowly elliptical becoming elliptical, with \pm smoothly rounded poles that often appear sharply pointed because of the overall shape of the valve, $30-50 \times 9.5-10.75 \mu \mathrm{m}$. Striae radiate throughout, more widely spaced but with no intercalated striae at the centre, 18.2-19.4-20.7 in $10 \mu \mathrm{m}$; some areolae visible in $\mathrm{LM}$, around the central area. Axial area narrow, occupying c. $20 \%$ of the valve width near the centre, represent-

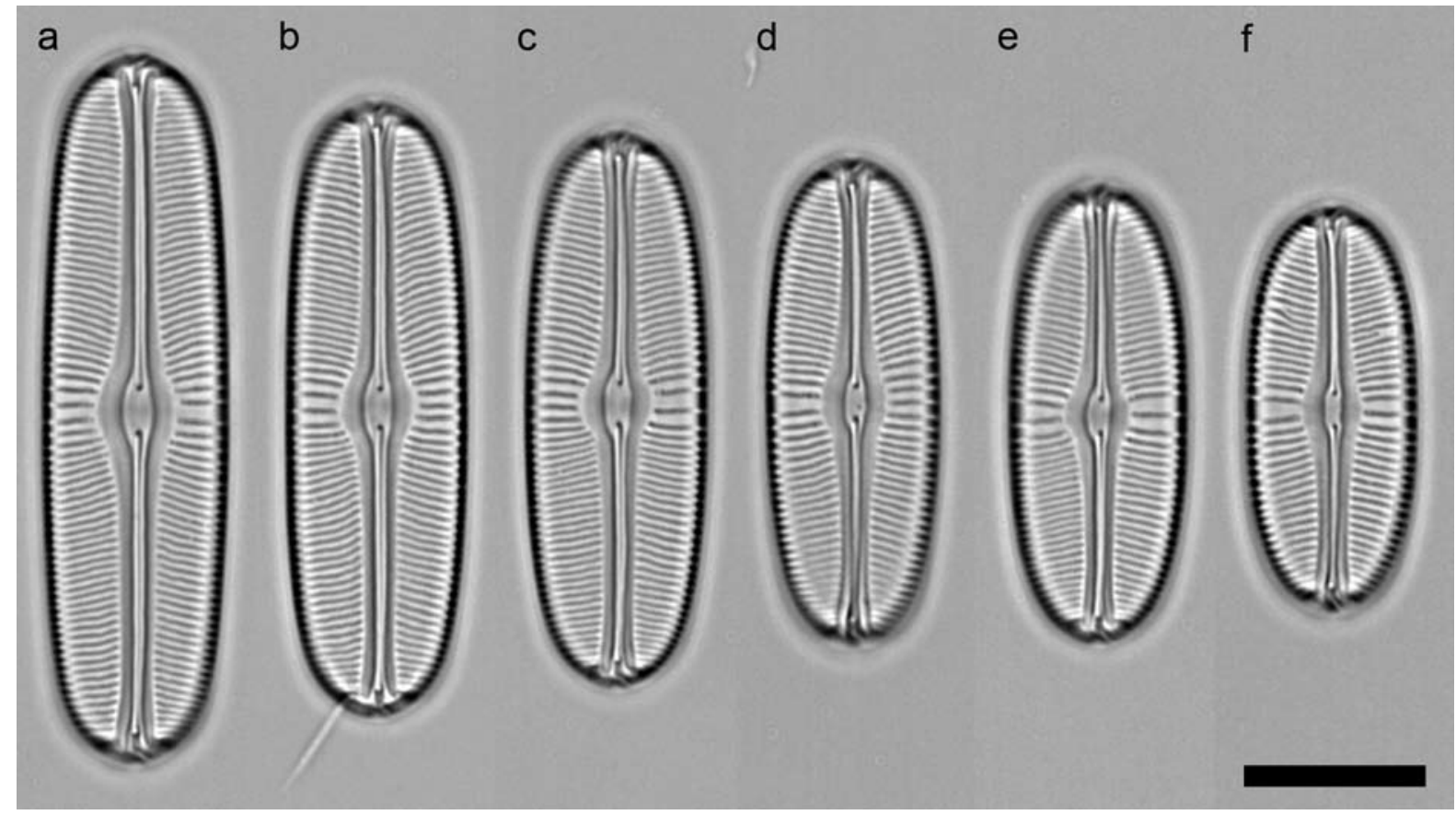

Fig. 5. Sellaphora [bacillum K-LB] $\Phi$ 'rectangular': Blackford Pond; (a-f) slide 'Blackford 18.12.86 thin 1'. Scale bar $=10$ $\mu \mathrm{m}$.

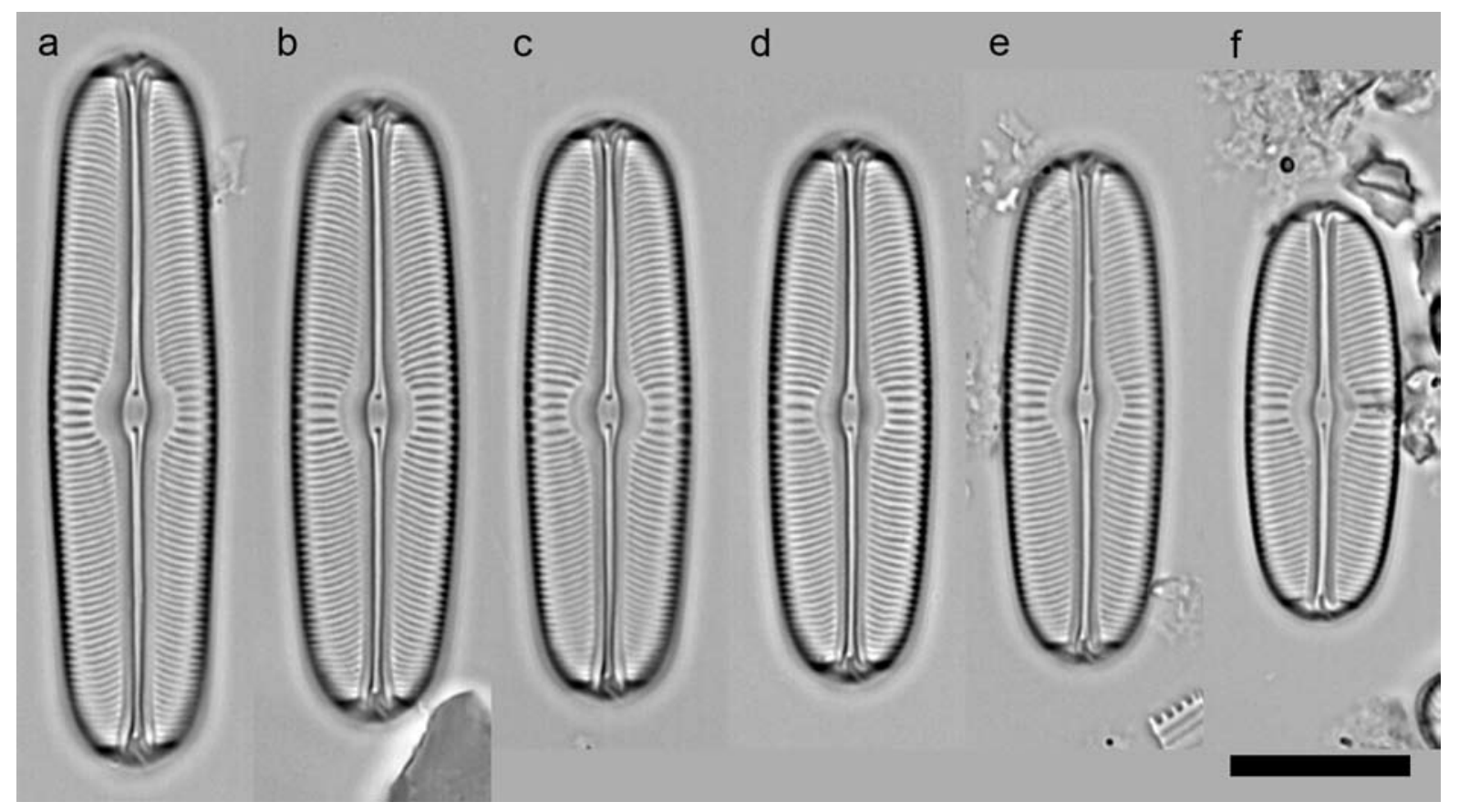

Fig. 6. Sellaphora [bacillum K-LB] $\Phi$ 'button’: Malham Tarn; (a-f) slide E3685/3. Scale bar $=10 \mu \mathrm{m}$. 
ing a depressed plain area covered by a narrow conopeum; central area expanded (to $30-50 \%$ of the valve width in longer specimens), welldefined, \pm circular. Raphe-sternum well-defined because of the adjoining depressed area, narrow, expanded into a narrowly elliptical 'central nodule' surrounding the central raphe endings. Raphe very slightly sinuous. Polar bars present, parallel or slightly radiate.

Sellaphora [bacillum K-LB] $\Phi$ 'butter' (Fig. 9) Valves narrowly elliptical becoming elliptical, with \pm smoothly rounded poles that often appear sharply pointed because of the overall shape of the valve, $19-39 \mu \mathrm{m} \times 8.75-9.75 \mu \mathrm{m}$. Striae radiate throughout, more widely spaced but with no

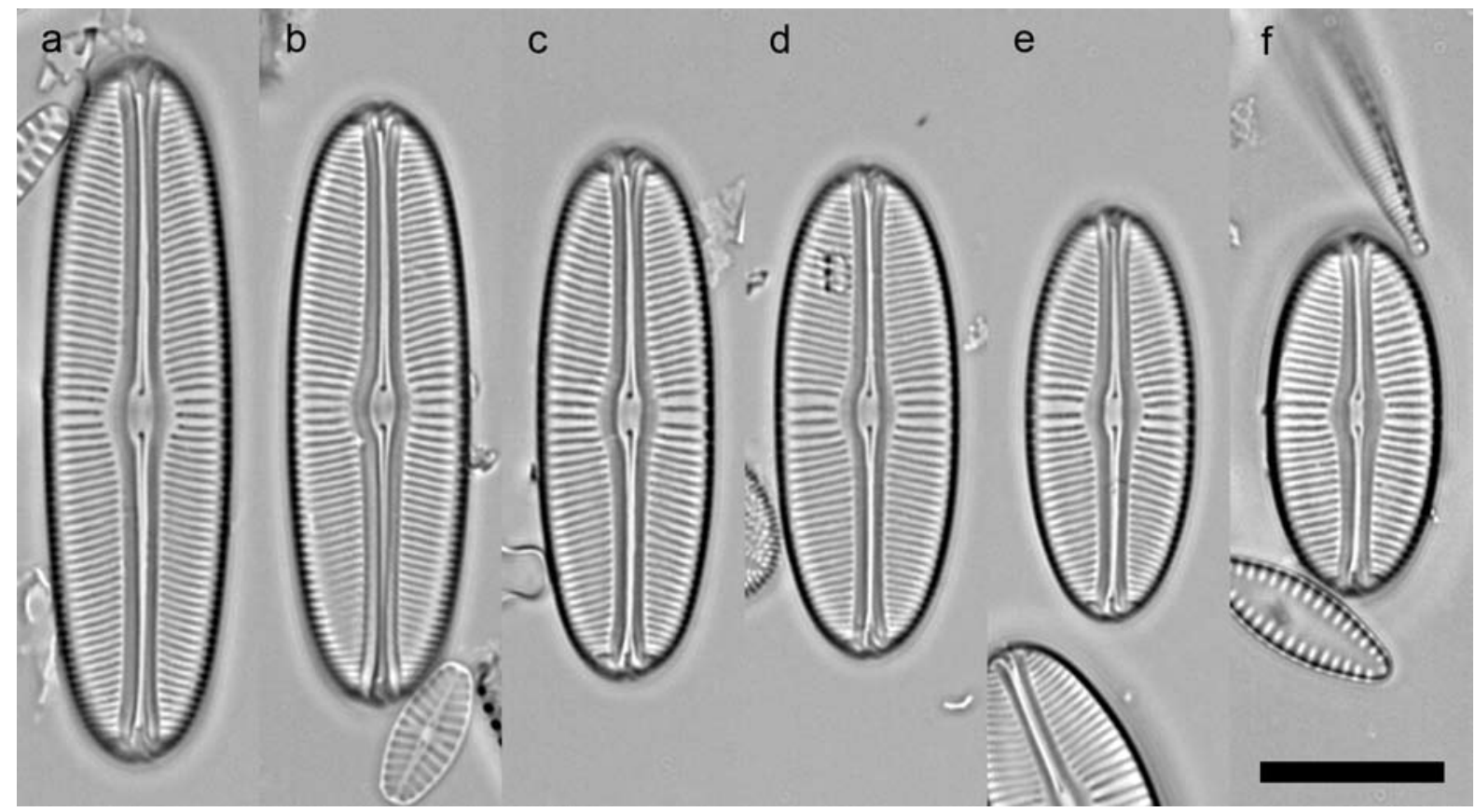

Fig. 7. Sellaphora [bacillum K-LB] $\Phi$ 'oval': Cole Mere; (a-f) slide E339/3. Scale bar $=10 \mu \mathrm{m}$.

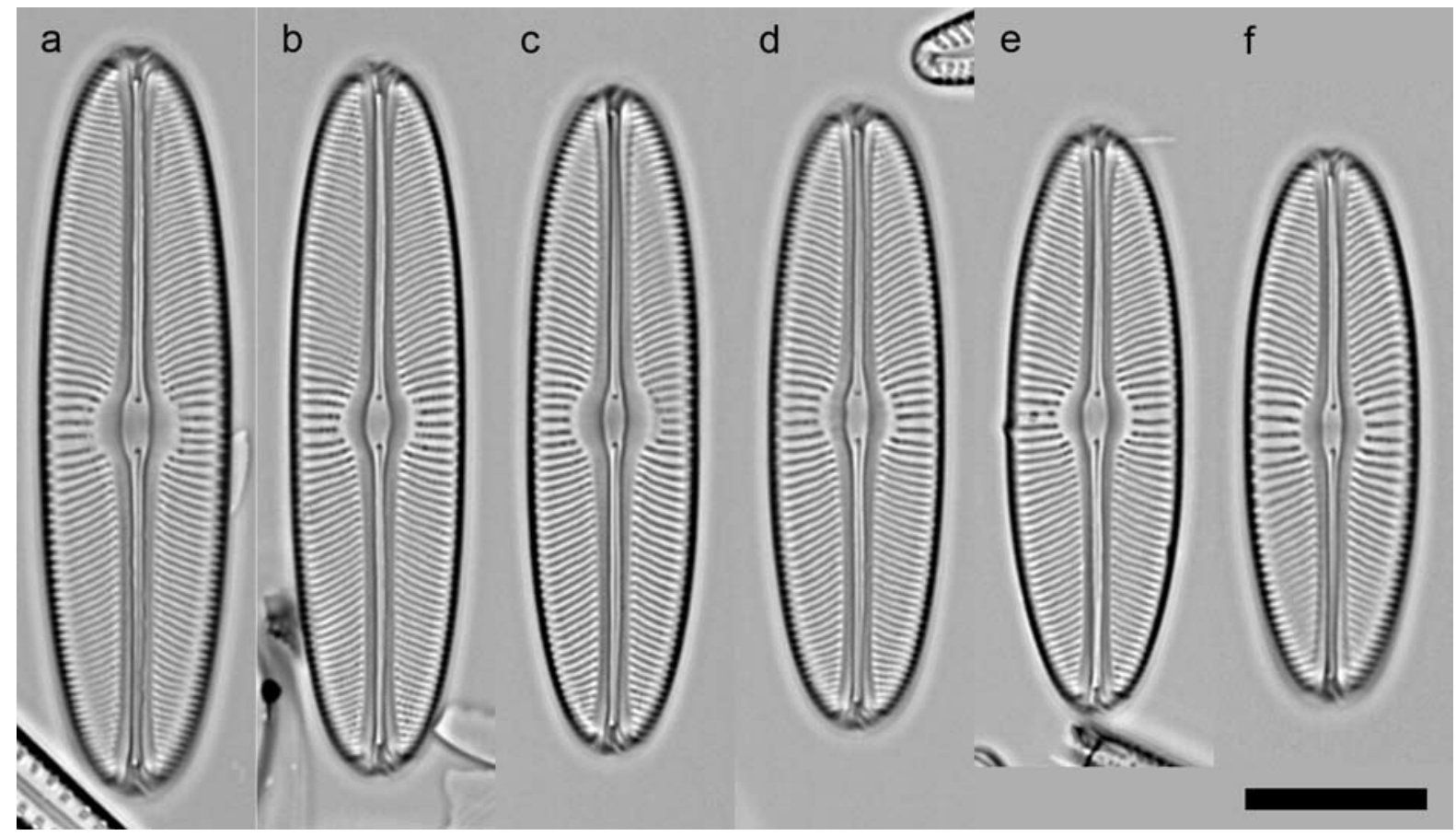

Fig. 8. Sellaphora [bacillum K-LB] $\Phi$ 'buttermax': Loch of Butterstone; (a-f) slide E3673/1. Scale bar $=10 \mu \mathrm{m}$. 
intercalated striae at the centre, $21.4-22.8-24.1$ in $10 \mu \mathrm{m}$; areolae invisible in LM. Axial area narrow, occupying c. $20 \%$ of the valve width near the centre, representing a depressed plain area covered by a narrow conopeum; central area expanded (to $35-55 \%$ of the valve width), with clear boundaries but merging gradually into the axial area, \pm circular. Raphe-sternum well-defined because of the adjoining depressed area, narrow, expanded into an elliptical 'central nodule' surrounding the central raphe endings. Raphe very slightly sinuous. Polar bars present, parallel or slightly radiate.

REMARKS: This phenodeme seems to bear a similar phenetic relationship to $\Phi$ 'buttermax' as $\Phi$ 'button' does to $\Phi$ 'rectangular'.

\section{Sellaphora [bacillum K-LB] Ф 'radiate' (Fig. 10)}

Valves elliptical, with \pm smoothly rounded poles that appear sharply pointed because of the overall shape of the valve, $31.5-47 \times 10.25-11.25 \mu \mathrm{m}$. Striae radiate throughout, slightly more widely spaced but with no intercalated striae at the centre, 20.5-22.0-22.8 in $10 \mu \mathrm{m}$; some areolae visible in LM, around the central area. Axial area narrow, occupying c. $20 \%$ of the valve width near the centre, representing a depressed plain area covered by a narrow conopeum. Central area expanded (to $40-45 \%$ of the valve width), moderately welldefined, circular or elliptical. Raphe-sternum well-defined because of the adjoining depressed area, narrow, expanded into a narrowly elliptical 'central nodule' surrounding the central raphe endings. Raphe very slightly sinuous. Polar bars present, slightly radiate.

REMARKs: Like $\Phi$ 'buttermax' but more finely striated and with a more simply elliptical outline.

\section{Sellaphora [bacillum K-LB] Ф 'gibbous' (Fig. 11)}

Valves linear-rhombic, becoming linear-elliptical, with rounded subacute poles, $18-38.5 \times 7.5-8.25$ $\mu \mathrm{m}$. Striae slightly radiate throughout, more widely spaced but with no intercalated striae at the centre, 20.4-21.5-23.0 in $10 \mu \mathrm{m}$; areolae invisible in LM. Axial area narrow, occupying c. $20 \%$ of the valve width near the centre, representing a depressed plain area covered by a narrow conopeum. Central area expanded (to $40-60 \%$ of the valve width), \pm well-defined, \pm circular. Raphe-sternum well-defined because of the adjoining depressed area, narrow, expanded into a narrowly elliptical 'central nodule' surrounding the central raphe endings. Raphe very slightly sinuous. Polar bars present, parallel.

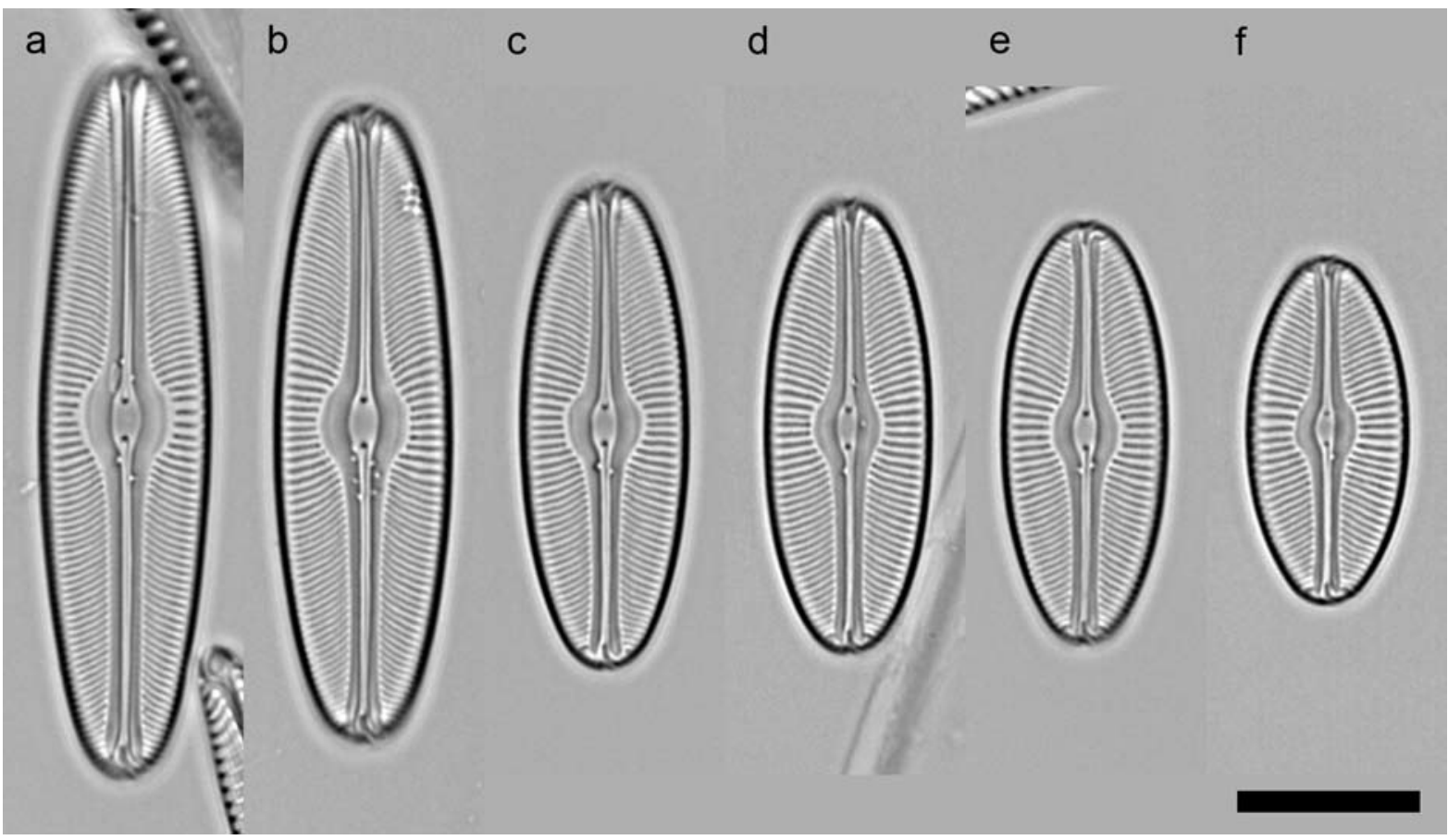

Fig. 9. Sellaphora [bacillum K-LB] $\Phi$ 'butter': Loch of Butterstone; (a-f) slide E3673/1. Scale bar $=10 \mu \mathrm{m}$. 


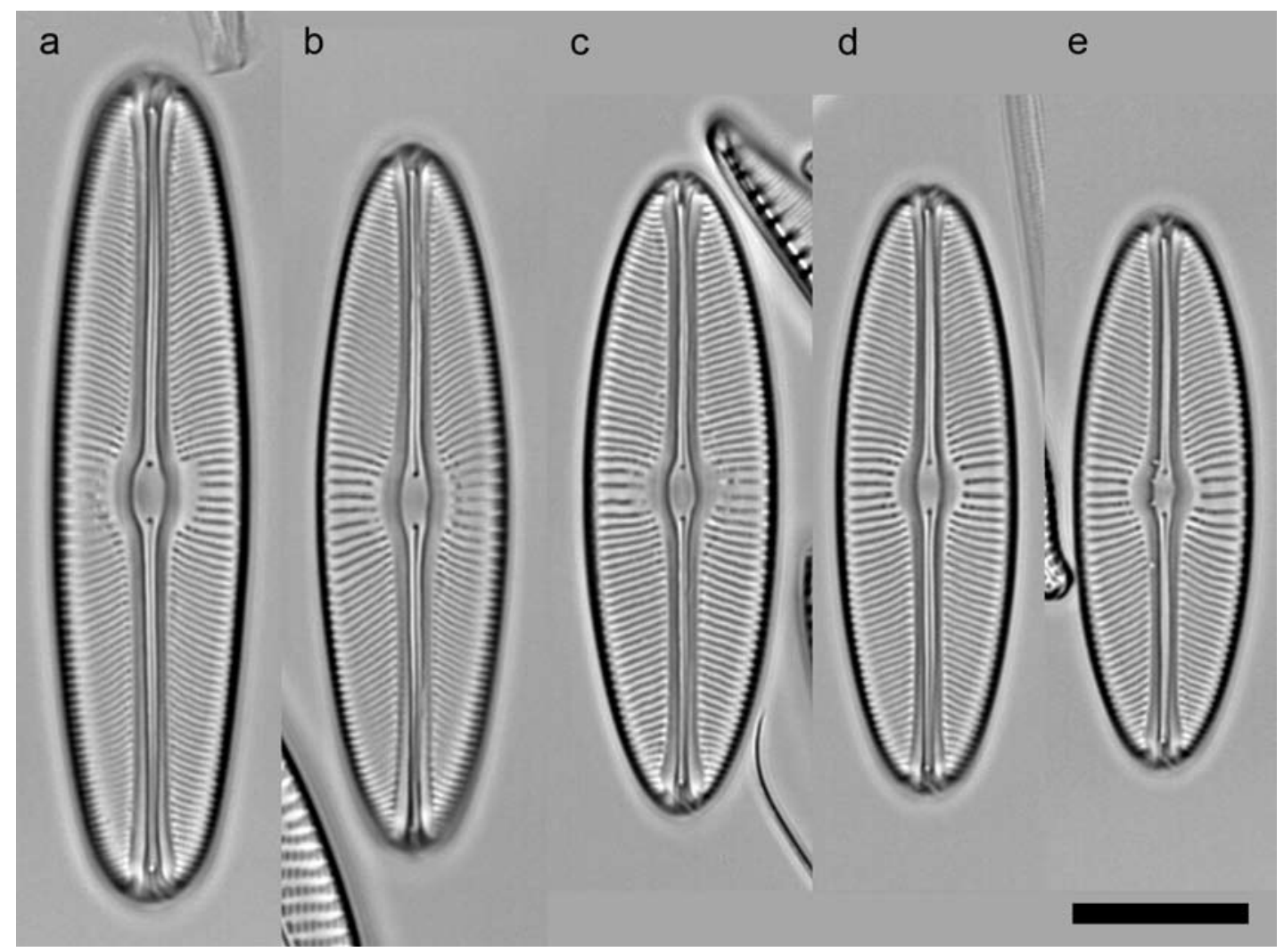

Fig. 10. Sellaphora [bacillum K-LB] $\Phi$ 'radiate': Loch Leven; (a-c, e) slide E3803/3; (d) slide E3803/1. Scale bar $=10 \mu \mathrm{m}$.

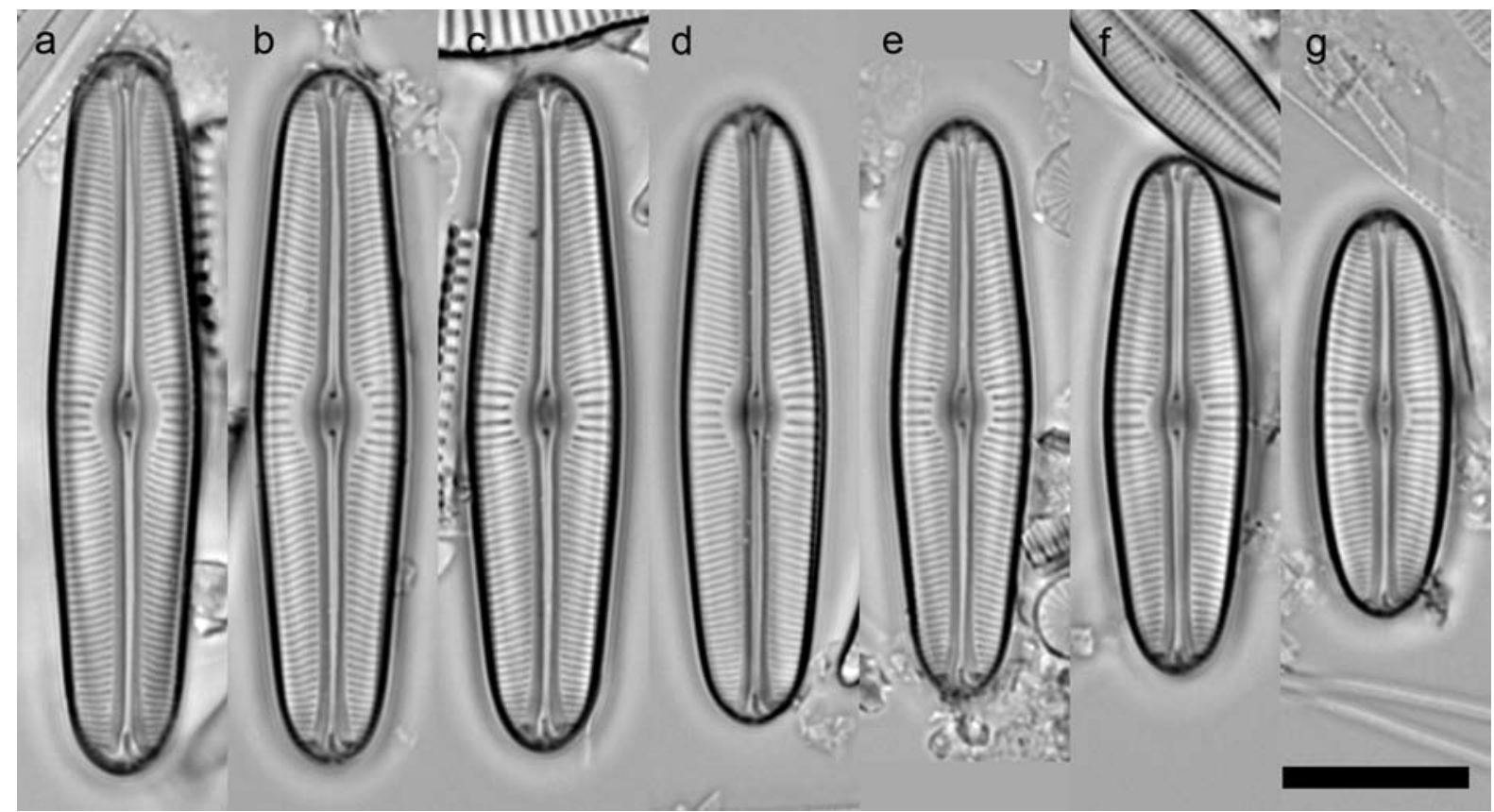

Fig. 11. Sellaphora [bacillum K-LB] $\Phi$ 'gibbous': Loch Leven; (a, c, d, f, g) slide E3832/4; (b, e) slide E3832/3. Scale bar = $10 \mu \mathrm{m}$. 


\section{Pupula Group}

Sellaphora [pupula K-LB] Ф 'lordly' (Fig. 12) Valves almost rhombic in the longest specimens, becoming elliptical, with subacute or subrostrate poles, $22-38.5 \times 8.5-9.25 \mu \mathrm{m}$. Striae radiate over most of the valve, becoming parallel very close to the poles, more widely spaced centrally with some intercalated striae, 20.4-22.0-23.5 in 10 $\mu \mathrm{m}$; areolae invisible in LM. Axial area widening towards the centre (becoming up to c. $30 \%$ of the valve width), including a depressed plain area adjacent to the raphe (?covered by a narrow conopeum); central area expanded (to 50-70\% of the valve width), somewhat irregular, transversely rectangular to bow-tie-shaped. Raphe-sternum well-defined because of the adjoining depressed area, very narrow, expanded into a narrowly elliptical 'central nodule' surrounding the central raphe endings. Raphe \pm straight. Polar bars present, parallel.

REMARKS: This is highly distinctive among British Sellaphora. A specimen of a similar diatom, though further along the size reduction sequence than any we have found thus far, was illustrated from an unspecified location in NW Siberia by LANGe-Bertalot \& GenkaL (1999, pl. 36, fig. 9), as S. pupula sensu lato.

\section{Sellaphora [pupula K-LB] Ф 'spike' (Fig. 13)}

Valves narrowly elliptical, with narrowly rostrate poles (overall, the shape is therefore 'lanceolate'), 22-34.5 × 8.0-9.25 $\mu \mathrm{m}$. Striae radiate and curved over most of the valve, becoming \pm parallel and occasionally angled near the polar bars, always with intercalated short striae at the centre, some of the longer central striae continued inwards as 'ghost striae', 18.0-19.2-20.5 in $10 \mu \mathrm{m}$; areolae invisible in LM. Axial area narrow. Central area expanded (to $40-50 \%$ of the valve width), somewhat irregular, transversely elliptical or transversely rectangular. Raphe-sternum bordered externally by prominent narrow grooves, which are discontinuous across the central area. Raphe \pm straight. Polar bars present, parallel.

Remarks: LeVkov et al. (2007, pl. 107, figs 1-3, 5-7 but not figs 4 and 8) illustrate six specimens of " $S$. $m u$ tatoides", 21-41.5 $\mu \mathrm{m}$ long, that resemble $\Phi$ 'spike' in outline, stria pattern and stria density (c. 19 in $10 \mu \mathrm{m}$ ), but are wider at any given length (e.g. by $0.5-1 \mu \mathrm{m}$ at c. $30 \mu \mathrm{m})$. The remaining two valves identified as " $S$. mutatoides" by LeVKov et al. (2007, pl. 107, figs 4, 8) correspond even better to our material. LEVKOV et al.'s material came from Lake Prespa, in the border area between Greece, Albania and the Republic of Macedonia; the type material of $S$. mutatoides, however, is from the nearby Lake Ohrid (Metzeltin \& LANGe-Bertalot 2002 , p. 64) and specimens from this material have apparently never been illustrated [it is not stated whether the single valve illustrated by KRAMMER \& LANGEBertalot (1986, pl. 68, fig. 17) and cited by Metzeltin \& Lange-Bertalot (2002, p. 64) is from Ohrid]. Instead, Metzeltin \& Lange-Bertalot 2002, pl. 31, figs 23, 24; pl. 34, fig. 13) illustrate specimens from Madagascar, one of which (pl. 34, fig. 13) is narrower than the others and falls outside the range given in the protologue (op. cit., p. 64). METZELTin \& LANGe-BERTALOT (2002) also assign to $S$. mutatoides the Mittersee (Austria) specimen illustrated by LANGe-BerTalot \& Metzeltin (1996, pl. 81, fig. 13). In view of the existence of another, apparently distinct deme resembling $S$. mutatoides, namely $\Phi$ 'lemon', the identity of genuine $S$. mutatoides from Lake Ohrid and its relationship to "mutatoides" from Lake Prespa, the Mittersee, and Ivato in Madagascar, and to $\Phi$ 'lemon' and $\Phi$ 'spike', require further investigation. Further specimens resembling $\Phi$ 'spike' are found in the arctic Bear Island (Norway) flora published by Metzeltin \& WitKowsKI (1996, as "Sellaphora pupula (Kütz.) Mereschkowsky var. pupula": see pl. 7, figs 10-12, but not fig. 13).

\section{Sellaphora [pupula K-LB] $\Phi$ 'grooved lanceo- late' (Fig. 14)}

Valves narrowly elliptical to elliptical, with rostrate poles (overall, the shape is therefore 'lanceolate'), $21-38 \times 7.25-8.25 \mu \mathrm{m}$. Striae radiate and slightly curved over most of the valve, often becoming angled near the poles and/or parallel or slightly convergent close to the polar bars, always with intercalated short striae at the centre, some of the longer central striae continued inwards as 'ghost striae', 20.4-21.5-22.8 in $10 \mu \mathrm{m}$; areolae invisible in LM. Axial area very narrow. Central area expanded (to c. $40-60 \%$ of the valve width), somewhat irregular, transversely rectangular to almost elliptical. Raphe-sternum bordered externally by prominent narrow grooves, which are discontinuous across the central area. Raphe \pm straight. Polar bars present, parallel or slightly convergent.

ReMARKS: Apparently the same deme was illustrated by Lange-Bertalot \& Metzeltin (1996, pl. 81, figs 16, 17) from the Mittersee, Austria, as "Morphotyp Nr. 1". Lange-Bertalot \& Metzeltin (1996, p. 280) note that this is a "Varietät mit enger gestellten Streifen und ausgeprägtem Conopeum."

\section{Sellaphora [pupula K-LB] $\Phi$ 'small lanceolate'} (Fig. 15)

Valves narrowly elliptical, with rostrate poles 


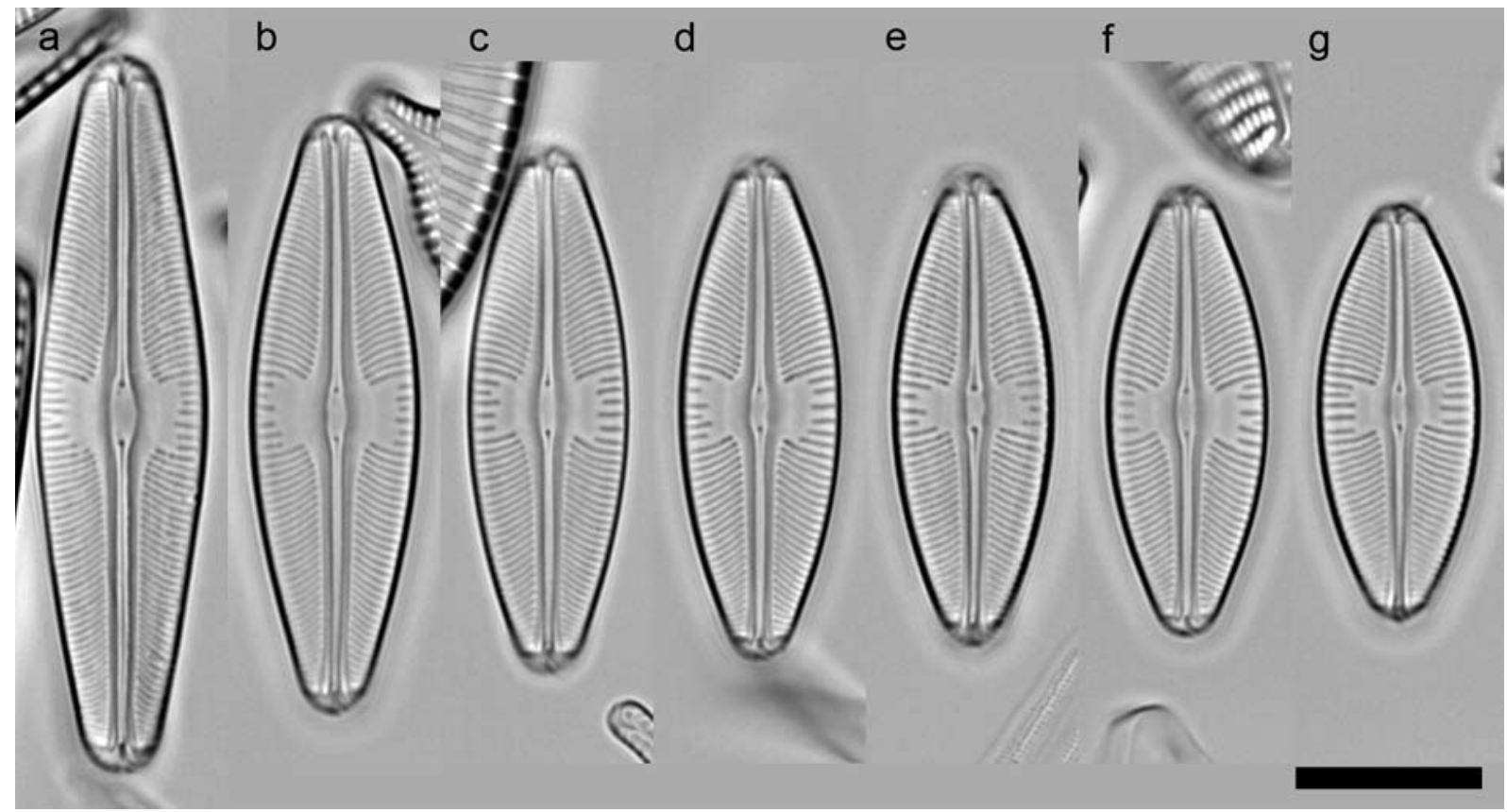

Fig. 12. Sellaphora [pupula K-LB] $\Phi$ 'lordly’: Loch Leven. (a-g) slide E3803/3. Scale bar $=10 \mu \mathrm{m}$.

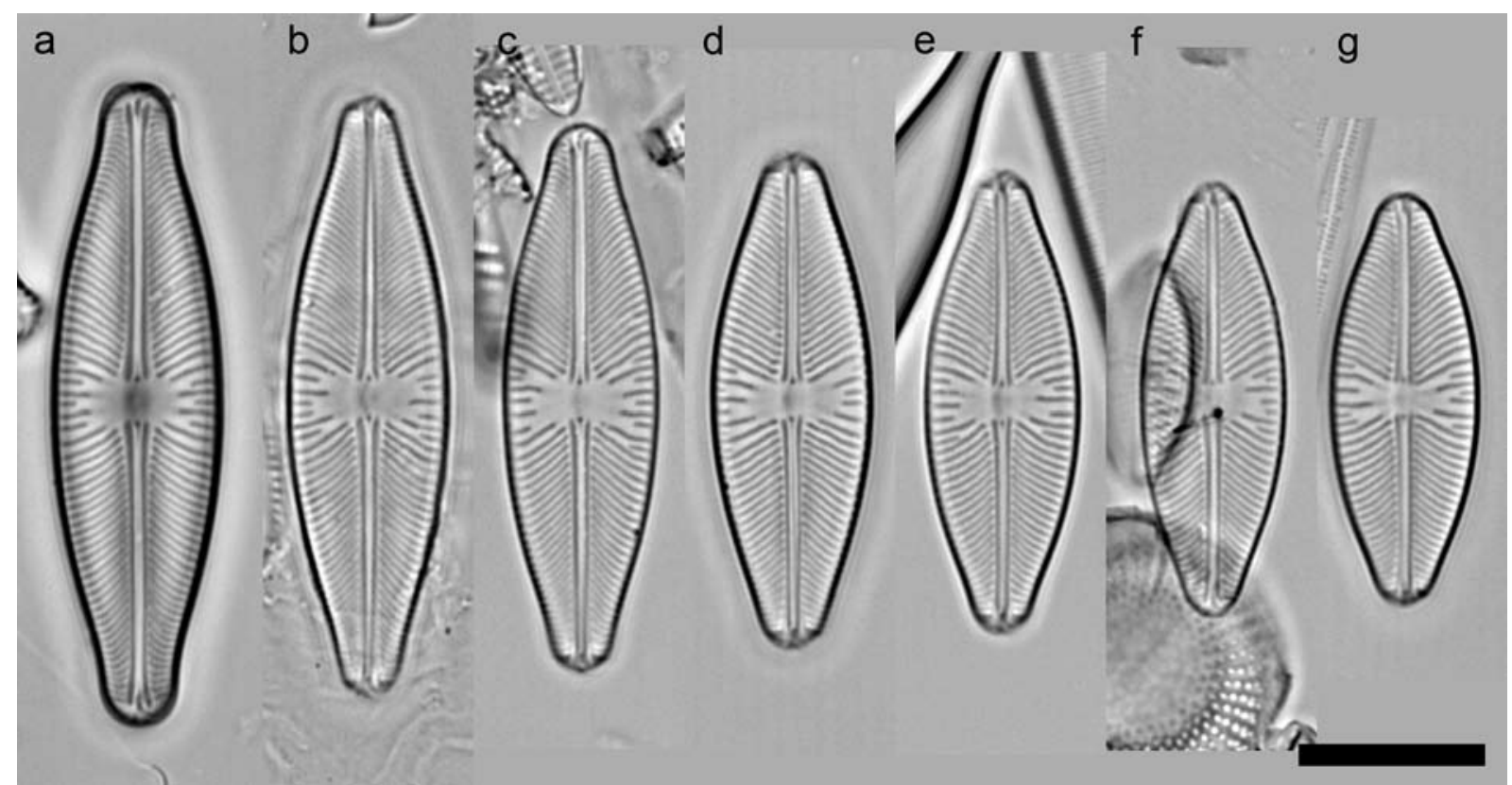

Fig. 13. Sellaphora [pupula K-LB] $\Phi$ 'spike': (a) Loch Leven, slide 3690/3; (b, c, f) Pick Mere, slide E341/A; (d, g) Loch Leven, slide E3830/6; (e) Loch Leven, E3830/3. Scale bar $=10 \mu \mathrm{m}$.

(overall, the shape is therefore 'lanceolate'), $17.5-30 \times 6.75-8.25 \mu \mathrm{m}$. Striae strongly radiate and curved over most of the valve, becoming \pm parallel and sometimes angled near the polar bars, always with intercalated short striae at the centre, some of the longer central striae continued inwards as 'ghost striae', 20.1-21.3-23.0 in $10 \mu \mathrm{m}$; areolae invisible in LM. Axial area very narrow. Central area expanded (to $35-55 \%$ of the valve width), somewhat irregular, transversely elliptical. Raphe-sternum bordered externally by prominent narrow grooves, which are discontinuous across the central area. Raphe \pm straight. Polar bars present, parallel. 


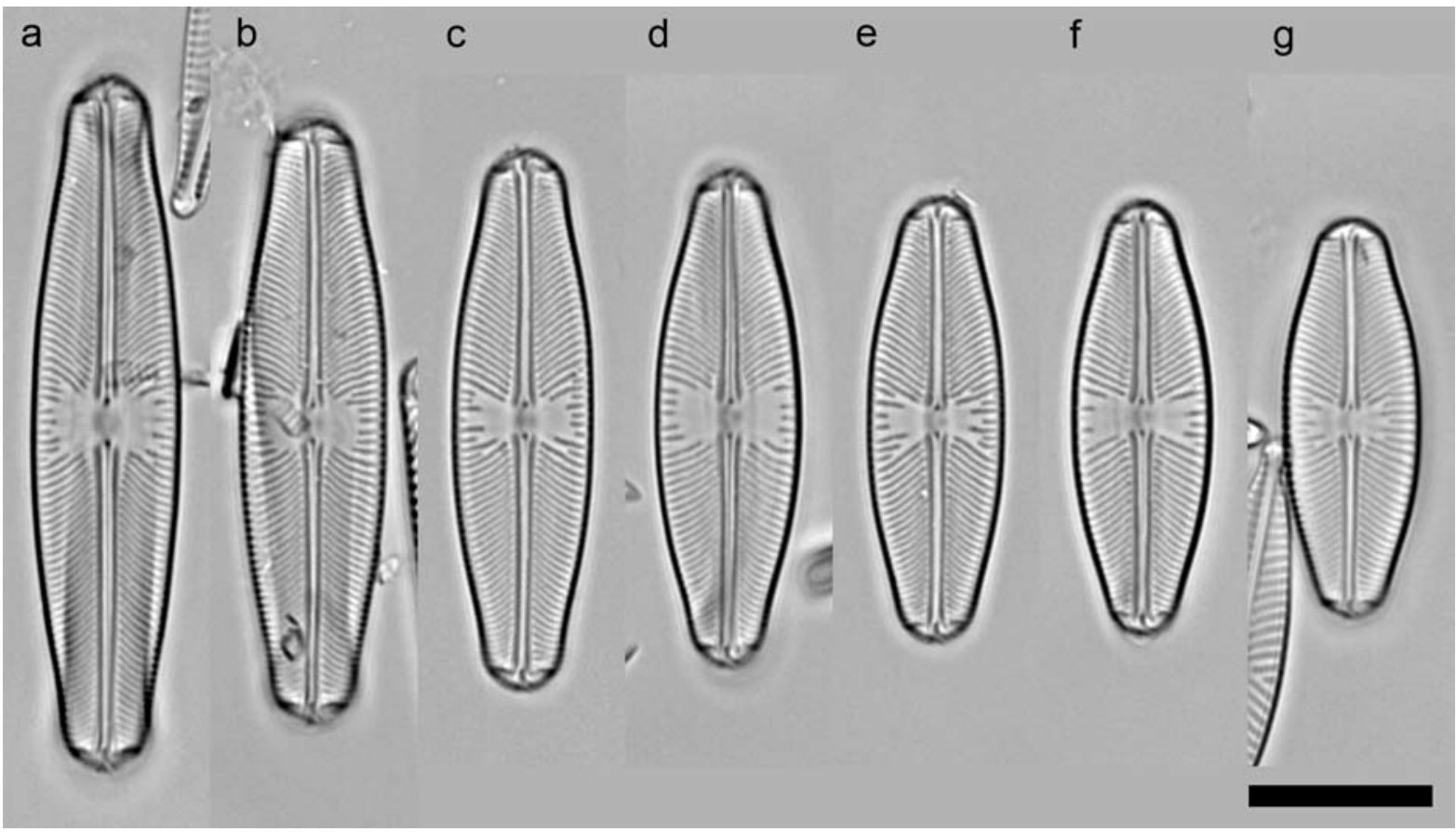

Fig. 14. Sellaphora [pupula K-LB] $\Phi$ 'grooved lanceolate': (a, e) Loch of Clunie, slide E328/3; (b, c) Loch of Craiglush, slide 323/2; (d, f) Loch Leven, slide E3830/3; (g) Malham Tarn, slide E3686/3. Scale bar $=10 \mu \mathrm{m}$.

\section{Sellaphora [pupula K-LB] $\Phi$ 'lemon' (Fig. 16)}

Valves elliptical, with narrow rostrate poles (the shape overall, therefore, is 'broadly lanceolate'), $19-28.5 \times 7.25-8.75 \mu \mathrm{m}$. Striae strongly radiate over most of the valve, sometimes angled and becoming \pm parallel very close to the polar bars, always with intercalated short striae at the centre, some of the longer central striae continued inwards as 'ghost striae', 19.3-20.1-21.2 in 10 $\mu \mathrm{m}$; areolae invisible in LM. Axial area very narrow. Central area expanded (to c. $30-50 \%$ of the valve width), somewhat irregular, almost circular to transversely elliptical. Raphe-sternum bordered externally by prominent narrow grooves, which are discontinuous across the central area. Raphe very slightly sinuous. Polar bars present, parallel.

REMARKs: The larger valve illustrated (Fig. 16a) may not belong to the same deme as the smaller ones. However, diatoms with a low aspect ratio (e.g. Cocconeis) often reduce more equally in length and breadth than more elongate diatoms (GeITLER 1932) and so, because this deme was rare in our material from Loch Leven and intermediates may have been missed, we have provisionally assigned all of the valves to the same deme. We would not be surprised to be proved wrong. Apparently the same deme was illustrated by LANGE-BERTALOT \& Metzeltin (1996, pl. 81, fig. 13) from the Mittersee, Austria, as "Sellaphora mutata (Krass.) Lange-Bertalot nov. comb." However, in the type material of S. mutata from Saxony, Germany, illustrated by LANGE-BERTALOT et al. (1996, pl. 18, figs 29-32) the valves are apiculate rather than rostrate and the striation density is c. 24 in $10 \mu \mathrm{m}$ (agreeing with KRASSKE's 1929 protologue). Metzeltin \& Lange-Bertalot (2002) recognized these discrepancies and specifically re-allocated the Mittersee specimen to their new species $S$. mutatoides, described from Lake Ohrid. However, although the striation densities are similar in all (19-22 in $10 \mu \mathrm{m})$, there is insufficient information about shape and size variation to determine whether $S$. mutatoides, the Mittersee specimen and $\Phi$ 'lemon' are truly alike, or whether $\Phi$ 'lemon' is homogeneous. The size reduction series of "S. mutatoides" illustrated by Levкоv et al. (2007, pl. 107, figs 1-8) from Lake Prespa suggests that the nearest equivalent of their diatom among our phenodemes is $\Phi$ 'spike' (q.v.), not $\Phi$ 'lemon'. Germain (1981, pl. 78 , fig. 13, as $S$. nyassensis) illustrated a diatom that seems to agree in all respects with the smaller valves of $\Phi$ 'lemon', but the habitat he describes (among Sphagnum near a peat-bog in Brittany) does not agree well with the known habitat of $\Phi$ 'lemon' (sandy sediments of the eutrophic Loch Leven).

\section{Sellaphora lanceolata (Fig. 17)}

Valves narrowly elliptical with rostrate poles (overall, the shape is therefore 'lanceolate'), (possibly 21.5: see 'Remarks') 24-31 × (7.1) 7.25$7.75(8.1) \mu \mathrm{m}$. Striae radiate over most of the valve, angled near the poles and then convergent close to the polar bars, always with intercalated 


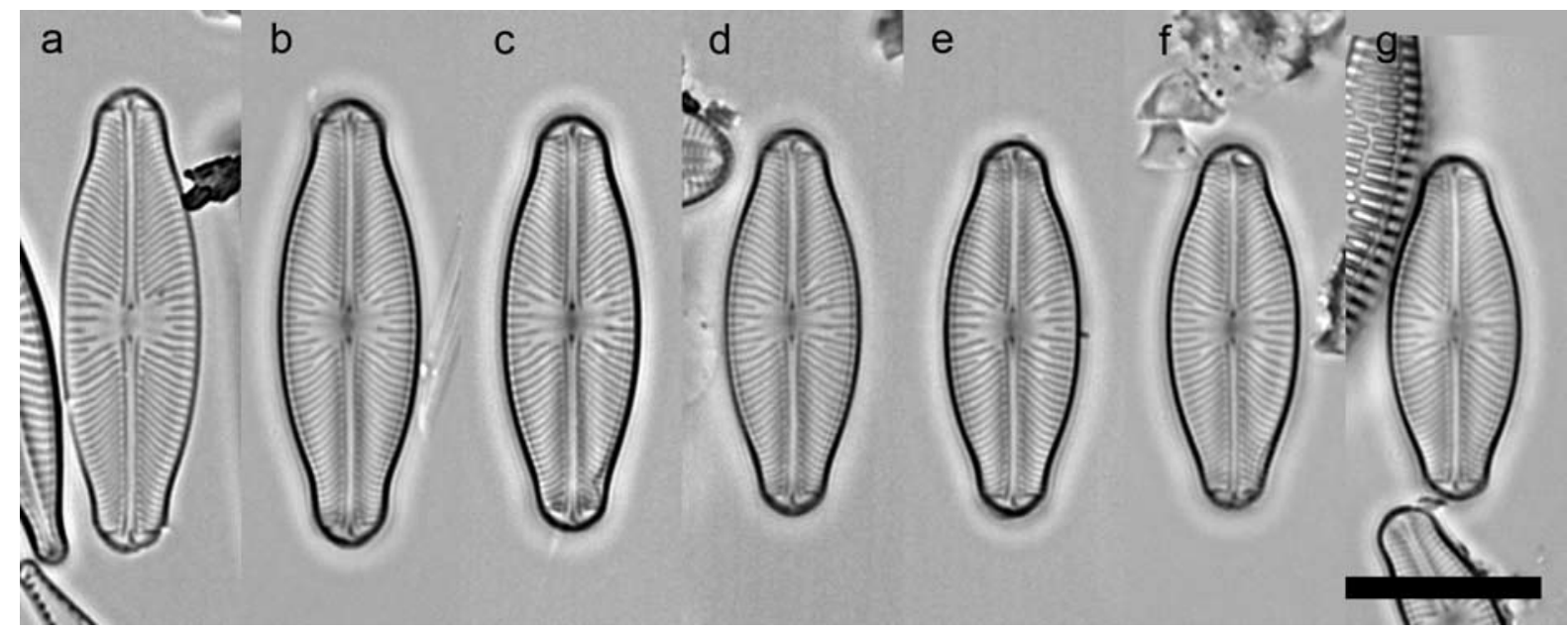

Fig. 15. Sellaphora [pupula K-LB] $\Phi$ 'small lanceolate': Threipmuir Reservoir. (a-g) slide E2588/3. Scale bar $=10 \mu \mathrm{m}$.

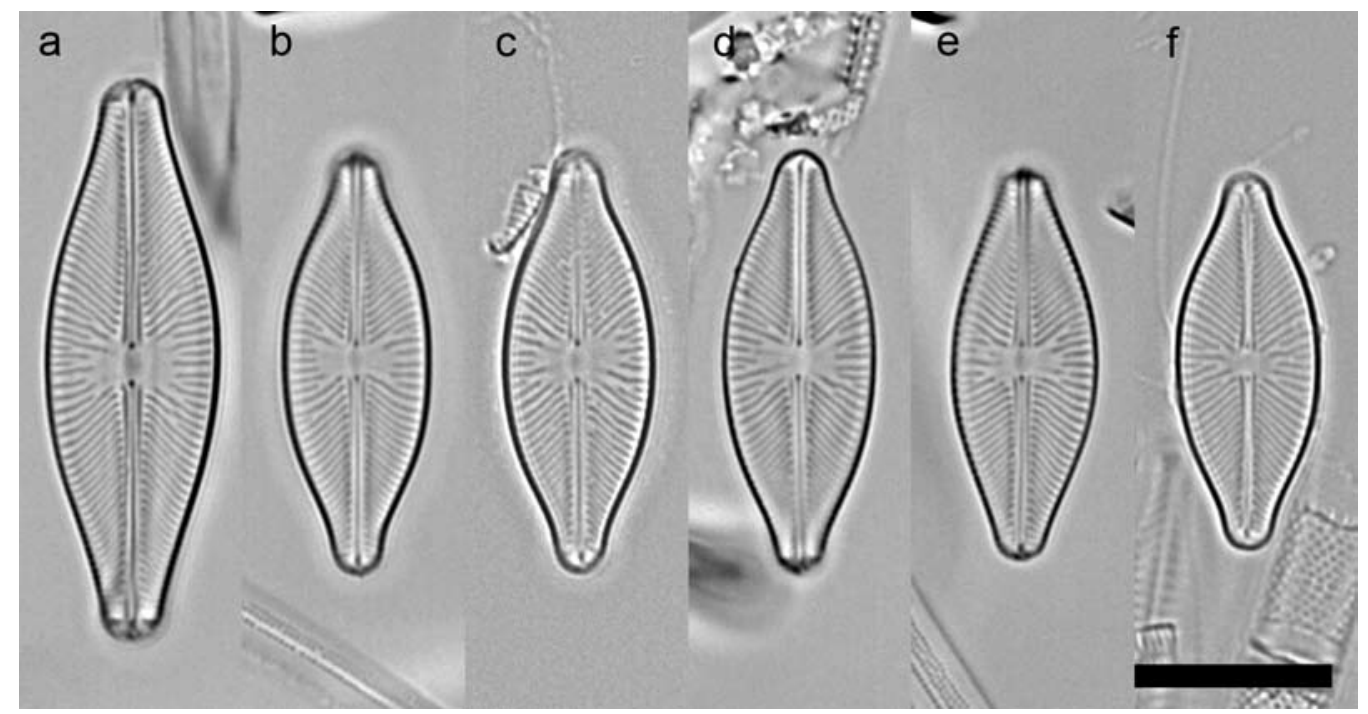

Fig. 16. Sellaphora [pupula K-LB] $\Phi$ 'lemon': Loch Leven. (a, b, e) slide E3830/3. (c, d, f) slide E3690/3. Scale bar = 10 $\mu \mathrm{m}$.

short striae at the centre, some of the longer central striae continued inwards as 'ghost striae', (18) 18.8-20.3-21.4 (21.5) in $10 \mu \mathrm{m}$; areolae invisible in LM. Axial area narrow. Central area expanded (to c. $45-55 \%$ of the valve width), somewhat irregular, almost round or elliptical to transversely rectangular. No grooves bordering the raphesternum visible in LM. Raphe straight. Polar bars present, convergent. DNA BARCODE (COX1): GenBank EF164953.

Remarks: Levkov et al. (2007, pl. 107, fig. 18) illustrate a valve resembling $S$. lanceolata, except that its poles are subcapitate. Metzeltin \& Lange-Bertalot (2007, pl. 161, figs $4-7$, probably not fig. 8) show stages in the size reduction of a deme corresponding well to $S$. lanceolata in valve outline, size, stria pattern and stria density. However, the micrographs (which are of high quality) show no sign of the 'ghost striae' always present in our material. In each of our samples, $S$. lanceolata usually showed a very narrow range of sizes, consistent with the idea (MANN et al. 2004) that it avoids size reduction. The valve shown in Fig. $17 \mathrm{~g}$ is unusually small and we assign it to $S$. lanceolata with some doubt.

\section{Sellaphora [pupula K-LB] $\Phi$ 'corpulent' (Fig.} 18)

Valves narrowly elliptical to elliptical, with very broadly rostrate poles (overall, the shape is therefore 'lanceolate'), 28.5-37.5 × 9.75-10.5 $\mu \mathrm{m}$. Striae slightly radiate and slightly curved over most of the valve, becoming angled near the poles and/or parallel or convergent close to the polar 


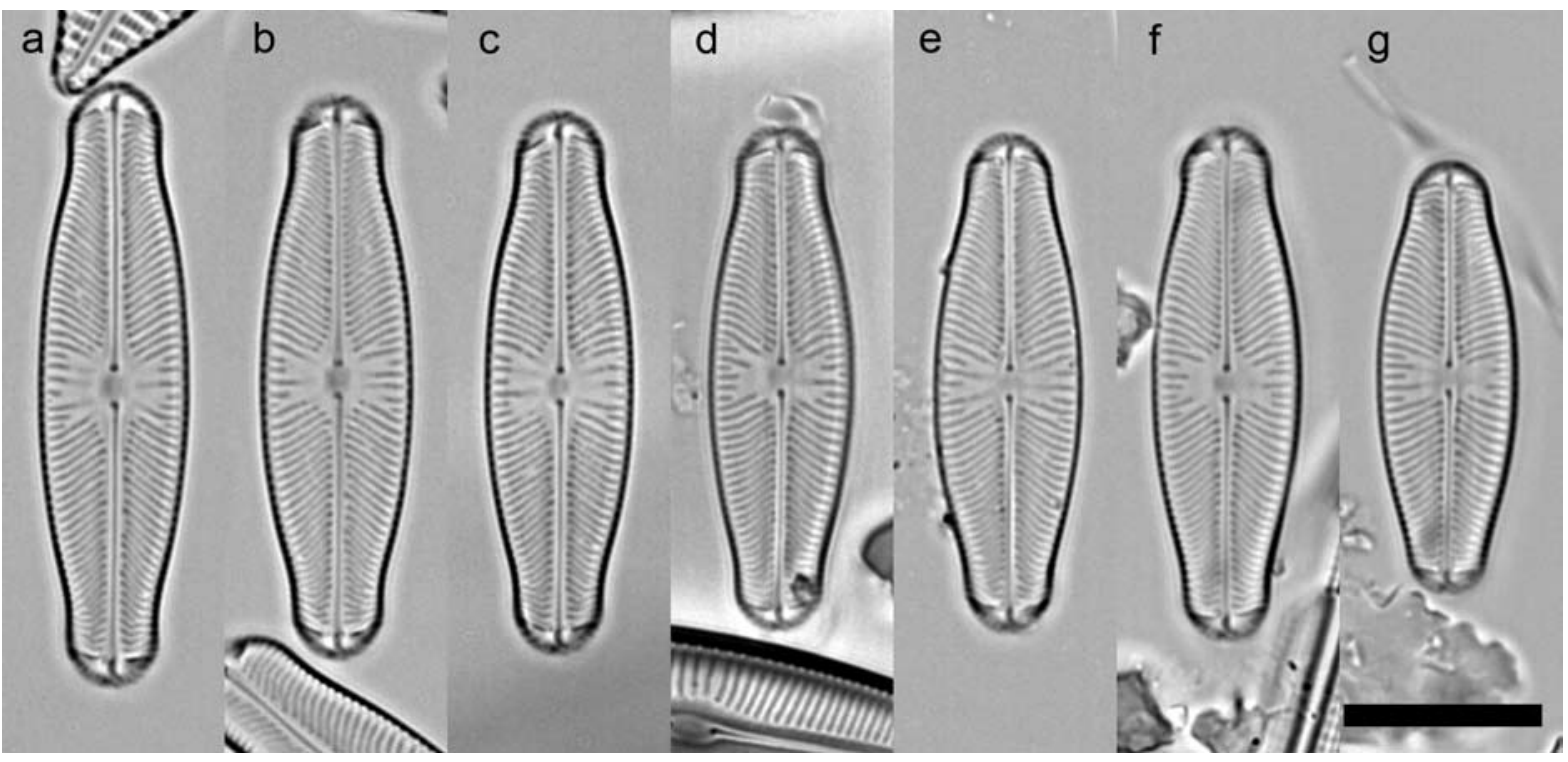

Fig. 17. Sellaphora lanceolata; (a-c) Blackford Pond, slide 'E16 Stand'; (d, f, g) Malham Tarn, slide E3685/3; (e) Dunsapie Loch, slide E3572. Scale bar $=10 \mu \mathrm{m}$.

bars, with few or no intercalated short striae at the centre, 19.2-19.9-21.0 in $10 \mu \mathrm{m}$; areolae invisible in LM. Axial area very narrow. Central area strongly expanded (to c. $70-75 \%$ of the valve width), \pm well-defined, transversely rectangular to slightly bow-tie-shaped. Raphe-sternum usually bordered externally by a well-marked groove or step, even in the central area. Raphe slightly sinuous. Polar bars present, parallel.

REMARKS: In dimensions, shape and striation pattern, $\Phi$ 'corpulent' resembles two valves from NW Siberia illustrated by Lange-Bertalot \& Genkal (1999, pl. 36, figs 11,12$)$. However, these are slightly more finely striated (with c. 22 striae in $10 \mu \mathrm{m}$ ) than our specimens and, probably more importantly, they possess a different axial area, possessing prominent but narrow grooves and conopea alongside the raphe-sternum, which are discontinuous across the central area (cf. Lange-Bertalot \& Genkal 1999, pl. 36, fig. 10), as in the 'spike', 'grooved lanceolate', 'small lanceolate' and 'lemon' phenodemes.

\section{Sellaphora [pupula K-LB] $\Phi$ 'cf. corpulent'} (Fig. 19)

Valves narrowly elliptical to elliptical, with broadly rostrate poles (overall, the shape is therefore 'lanceolate'), $25.5-46.5 \times 9.5-10.25 \mu \mathrm{m}$. Striae radiate and slightly curved over most of the valve (but sometimes almost parallel centrally), becoming angled near the poles and parallel or convergent close to the polar bars, with some intercalated short striae at the centre, 19.1-20.1-20.9 in
$10 \mu \mathrm{m}$; areolae invisible in LM. Axial area very narrow. Central area strongly expanded (to c. $60-65 \%$ of the valve width), somewhat irregular, transversely rectangular to transversely elliptical. Raphe-sternum usually bordered externally by a well-marked groove or step, even in the central area. Raphe very slightly sinuous. Polar bars present, convergent to parallel.

RemARKs: Like $\Phi$ 'corpulent' in stria pattern and density, but intermediate betweeen this and $S$. obesa in dimensions.

\section{Sellaphora obesa (Fig. 20)}

Valves narrowly elliptical to elliptical, with broadly rostrate poles (overall, the shape is therefore 'lanceolate'), (20) 21.5-47.5 × (8) 8.75-10.0 $\mu \mathrm{m}$. Striae radiate and straight to slightly curved over most of the valve, becoming parallel or convergent close to the polar bars and some usually obviously angled, with a few intercalated short striae at the centre, 18.0-18.7-20.7 (21.5) in 10 $\mu \mathrm{m}$; areolae invisible in LM. Axial area narrow. Central area strongly expanded (to $60-70 \%$ of the valve width), somewhat irregular, transversely rectangular to bow-tie-shaped. Raphe-sternum bordered externally by a groove or step, even in the central area. Raphe very slightly sinuous. Polar bars present, parallel to convergent.

REMARKS: Apparently the same diatom was illustrated by Germain (1981, pl. 78, figs 4, 5). Germain did not separate it from $S$. pupula. 


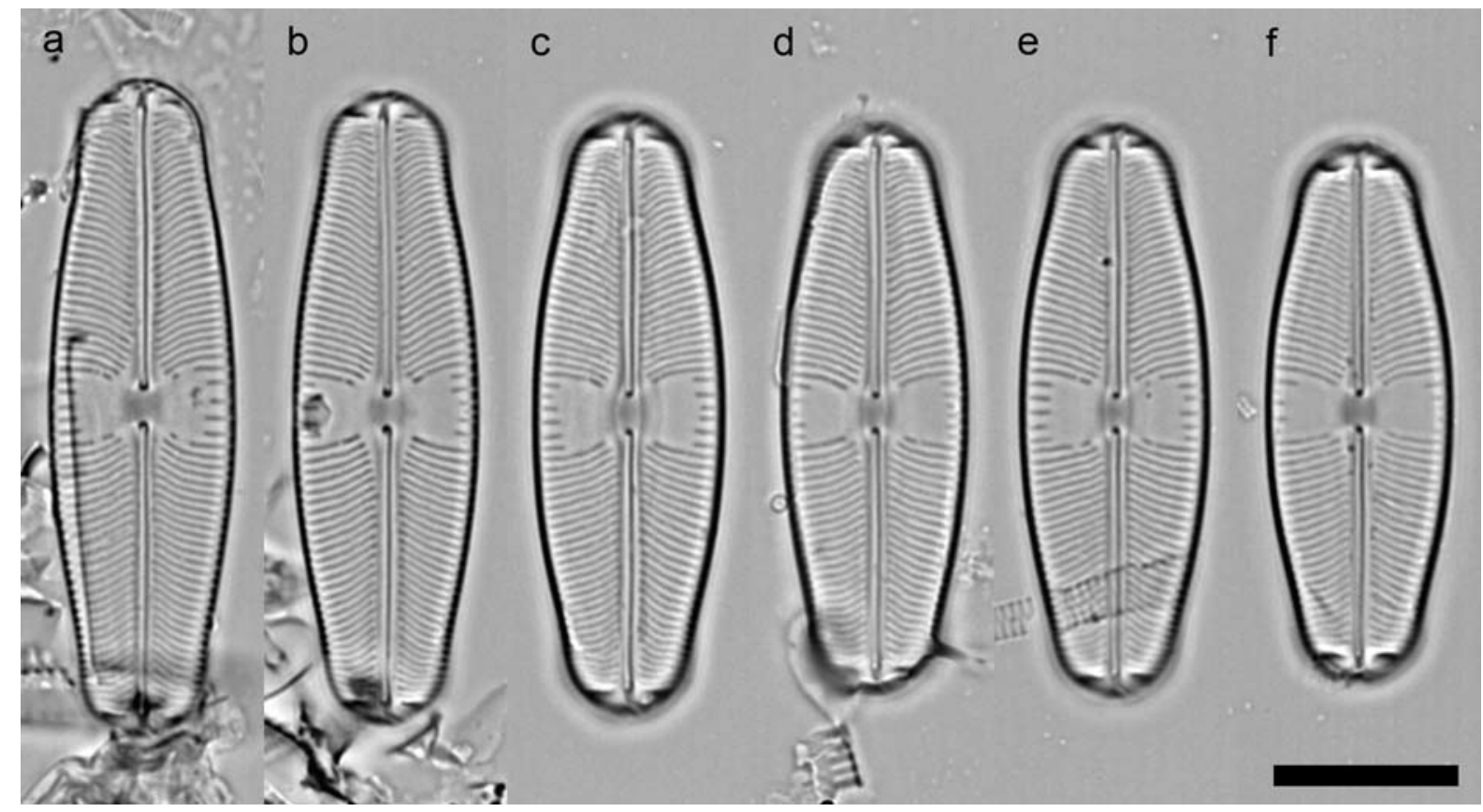

Fig. 18. Sellaphora [pupula K-LB] $\Phi$ 'corpulent': Little Water; (a-f) slide 'B', K. Atkinson. Scale bar $=10 \mu \mathrm{m}$.

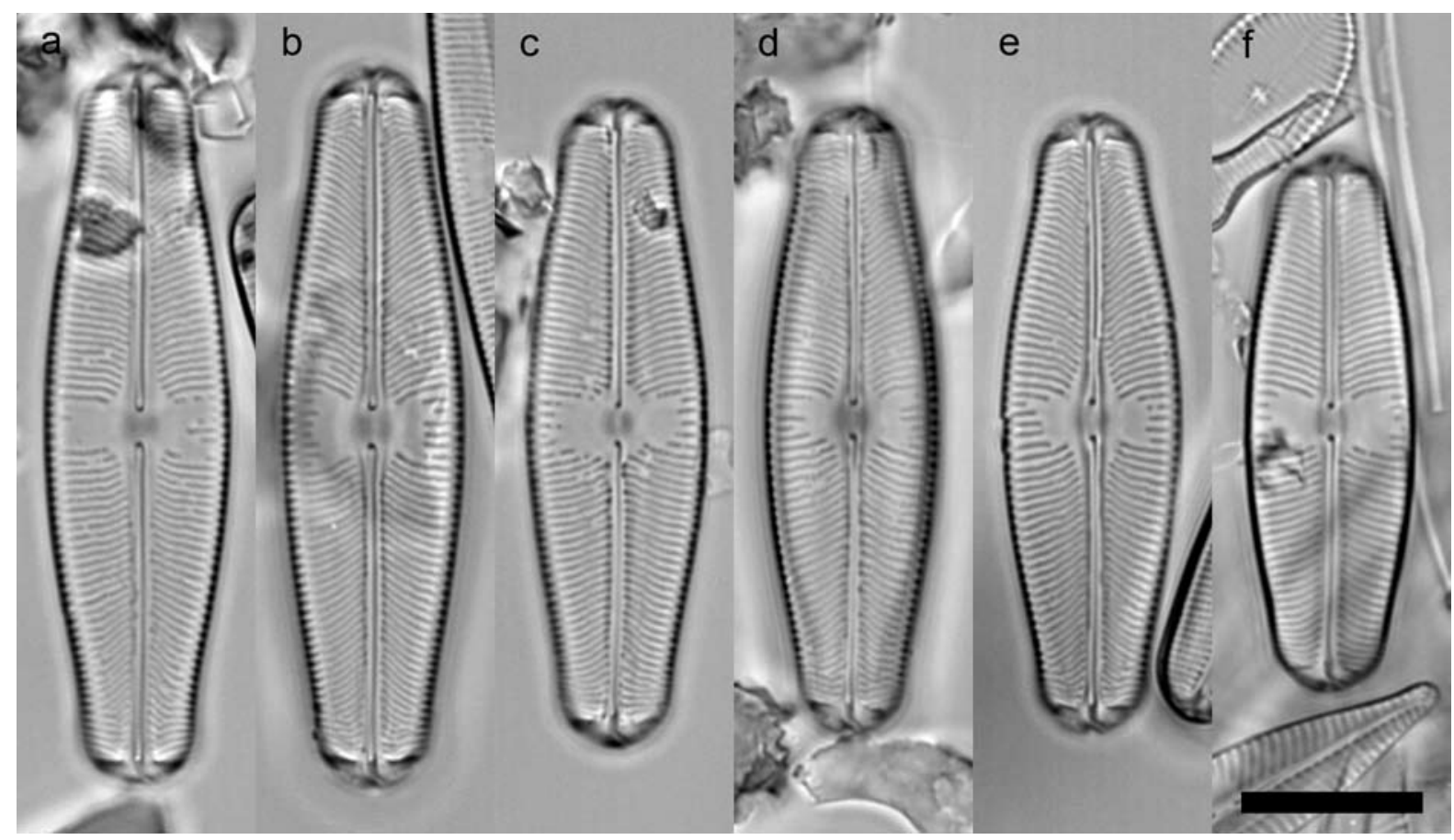

Fig. 19. Sellaphora [pupula K-LB] $\Phi$ ‘cf. corpulent’: (a-e) Lindean Reservoir, slide E88 sonic; (f) Loch of Drumellie, E329/2. Scale bar $=10 \mu \mathrm{m}$. 


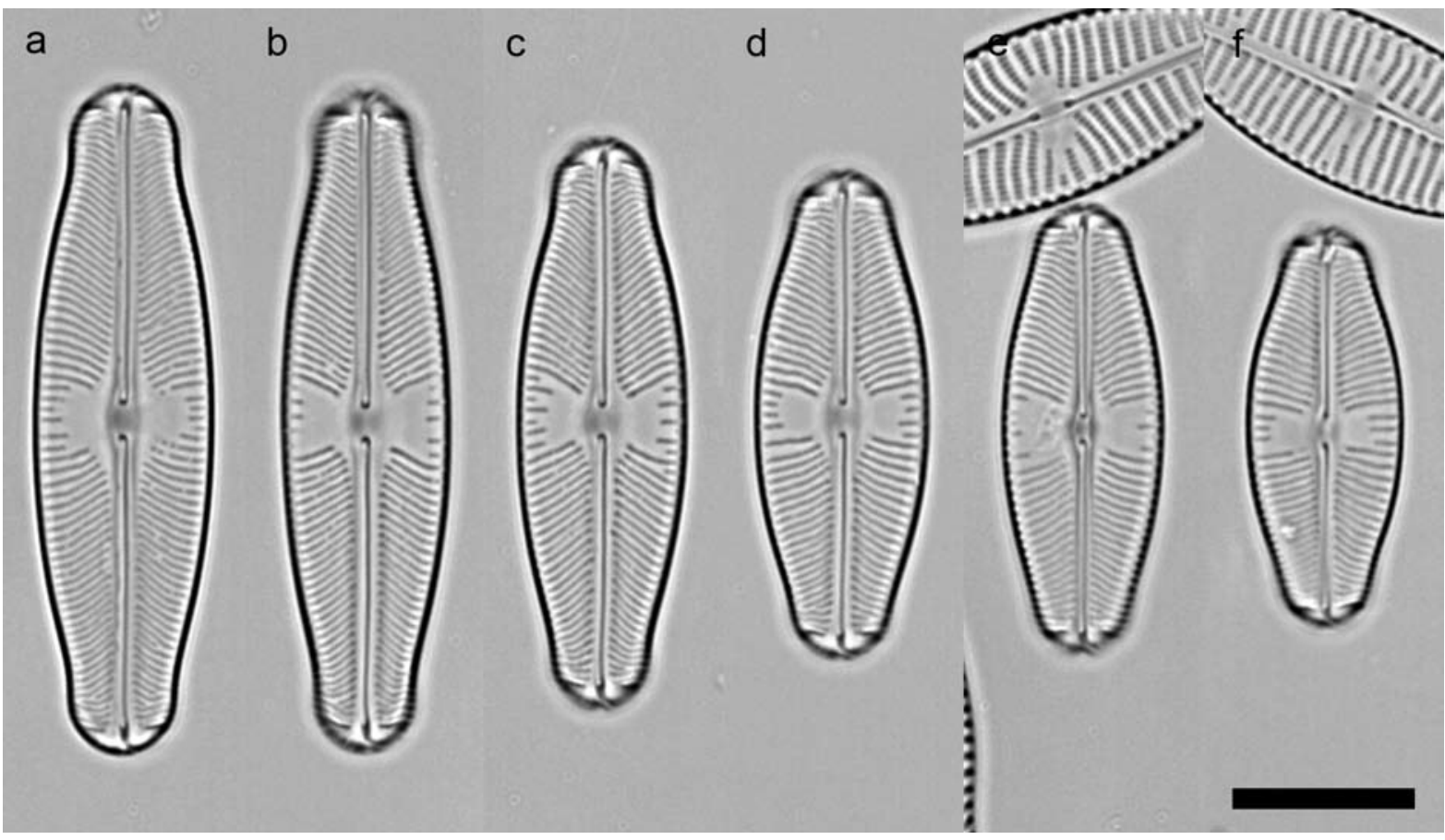

Fig. 20. Sellaphora obesa: Blackford Pond; (a-f) slide '18.12.86 thin 1'. Scale bar $=10 \mu \mathrm{m}$.

\section{Sellaphora [pupula K-LB] Ф 'meso-obese' (Fig.} 21)

Valves narrowly elliptical, with broadly rostrate poles (overall, the shape is therefore 'lanceolate'), $26-32.5 \times 8.25-8.75 \mu \mathrm{m}$. Striae radiate and straight to slightly curved over most of the valve, becoming parallel or convergent close to the polar bars, with a few intercalated short striae at the centre, 18.3-19.6-21.0 in $10 \mu \mathrm{m}$; areolae invisible in LM. Axial area narrow. Central area strongly expanded (to $65-75 \%$ of the valve width), somewhat irregular, transversely \pm rectangular. Raphe-sternum bordered externally by a shallow groove or step, even in the central area. Raphe very slightly sinuous. Polar bars present, parallel or slightly convergent.

Remarks: Like $S$. obesa in all respects apart from its dimensions, being narrower for any given length.

\section{Sellaphora [pupula K-LB] Ф 'mini-obese' (Fig. 22)}

Valves narrowly elliptical to elliptical, with broadly rostrate poles (overall, the shape is therefore 'lanceolate'), $13.5-37.5 \times 7.0-8.75 \mu \mathrm{m}$. Striae radiate and straight to slightly curved over most of the valve, becoming parallel or convergent close to the polar bars, with some intercalated short striae at the centre, sometimes with some of the longer central striae continued inwards as 'ghost striae', $18.7-19.2-20.5$ in $10 \mu \mathrm{m}$; areolae invisible in LM. Axial area very narrow. Central area strongly expanded (usually to $60-70 \%$ of the valve width, but sometimes to only $45 \%$ in the smallest specimens), somewhat irregular, transversely \pm rectangular. No obvious groove alongside the raphe-sternum. Raphe straight. Polar bars present, parallel to convergent.

REmarks: This is the smallest of the 'obesa series'.

\section{Sellaphora [pupula K-LB] $\Phi$ 'wide tidy' (Fig. 23)}

Valves narrowly elliptical with very broadly rostrate to subcapitate poles (overall, the shape is therefore 'lanceolate'), $25-35.5 \times 8-8.75 \mu \mathrm{m}$. Striae radiate and slightly curved, with some intercalated short striae at the centre, 20.7-21.722.6 in $10 \mu \mathrm{m}$; areolae invisible in LM. Axial area very narrow. Central area strongly expanded (to $60-65 \%$ of the valve width), \pm well-defined, bowtie-shaped. Raphe-sternum narrow, bordered externally by shallow grooves. Raphe slightly sinuous. Polar bars present, radial or parallel.

\section{Sellaphora [pupula K-LB] Ф 'tidy' (Fig. 24)}

Valves narrowly elliptical with broadly rostrate to subcapitate poles (overall, the shape is therefore 'lanceolate'), $17.5-33.5 \times 6.75-8.5 \mu \mathrm{m}$. Striae radiate and slightly curved over most of the valve, 
becoming parallel near the poles, with some intercalated short striae at the centre, 20.9-23.1-25.5 in $10 \mu \mathrm{m}$; areolae invisible in LM. Axial area very narrow. Central area strongly expanded (to $60-65 \%$ of the valve width), \pm well-defined, bowtie-shaped. Raphe-sternum narrow, bordered externally by shallow grooves. Raphe very slightly sinuous. Polar bars present, parallel.

Remarks: Lange-Bertalot \& Metzeltin (1996, pl. 25, fig. 6) illustrate a single valve $(24 \times 7.9 \mu \mathrm{m}$, with c. 21 striae in $10 \mu \mathrm{m}$ ) from Lake Julma Ölkky, Finland, which closely resembles $\Phi$ 'tidy'. It was identified by Lange-Bertalot \& Metzeltin as "Sellaphora pupula (Kütz.) Mereschkowsky var. pupula", but this was before the second-step lectotypification of S. pupula by MANN (2001).

\section{Sellaphora [pupula K-LB] $\Phi$ 'slender' (Fig. 25)}

Valves narrowly elliptical with capitate to subcapitate poles (overall, the shape is therefore 'lanceolate'), $23.5-41 \times 6.5-7.75 \mu \mathrm{m}$. Striae radiate and curved, becoming parallel towards the poles, with some intercalated short striae at the centre, 24.826.3-27.9 in $10 \mu \mathrm{m}$; areolae invisible in LM. Axial area narrow. Central area strongly expanded (to $60-65 \%$ of the valve width), somewhat irregular, \pm bow-tie-shaped to transversely rectangular or almost elliptical. Raphe-sternum narrow, apparently bordered externally on each side by a shallow groove or step that is continuous across the central area. Raphe sinuous. Polar bars present, parallel or slightly radiate.

REMARKs: Apparently the same deme was described as $S$. pupula var. densistriata by LANGe-BeRTAlot \& Metzeltin (1996, p. 102, pl. 25, fig. 9) from Lake Julma Ölkky, Finland, and elevated to species rank by Metzeltin \& Lange-Bertalot (2002, p. 58). The only metric data supplied by these authors were stria densities (25-28 in $10 \mu \mathrm{m}$ near the centre), which agree with our data. The single specimen illustrated by Lange-Bertalot \& Metzeltin measures $37 \times 7.7 \mu \mathrm{m}$ and corresponds almost exactly to our Fig. 25b. Two other micrographs published by LANGe-Bertalot \& Metzeltin (1996, pl. 81, figs 18, 19) for comparison with $S$. densistriata but labelled as "Morphotyp Nr. 2 Mittersee" seem to represent a significantly wider diatom (valve dimensions $42 \times 8.5 \mu \mathrm{m}$ and $46.5 \times 9.0$ $\mu \mathrm{m}$ ) that is less finely striate (c. 23-24 striae in $10 \mu \mathrm{m}$ measured on the photographs). LevKov et al. (2007) revert to LANGe-Bertalot \& Metzeltin's (1996) classification, in which densistriata is treated as a variety of S. pupula. The valve they illustrate from Lake Prespa (Levkov et al. 2007, pl. 107, fig. 16) has more narrowly rostrate poles than $\Phi$ 'slender' -4.75 vs. $5.25 \mu \mathrm{m}$ (at $41 \mu \mathrm{m}$ long, the nearest equivalent among our valves is Fig. 25a) - and the striation density of the Prespa specimen (though difficult to measure from the photograph) appears to be $22-24$ in $10 \mu \mathrm{m}$. It is unlikely that this valve belongs to the same phenodeme as $\Phi$ 'slender' or $S$. densistriata sensu Lange-Bertalot \& Metzeltin (1996). Metzeltin \& Lange-Bertalot (2007) illustrate three valves identified as "Sellaphora cf. densistriata" from Novrague, French Guiana, which are much larger and more robust than $\Phi$ 'slender' (41.5-45.5 × 9-9.5 $\mu \mathrm{m}$, with c. 22 striae in $10 \mu \mathrm{m}$ ) and cannot be assigned to the same phenodeme. None of the valves from Uruguay identified as $S$. densistriata by Metzeltin et al. (2005, pl. 64, figs 1-5, 10-12, 37) agree in shape or striation pattern with $\Phi$ 'slender' or with the original material from Julma Ölkky and we wonder if they were accidentally mislabelled.

\section{Sellaphora [pupula K-LB] $\Phi$ 'refined' (Fig. 26)}

Valves narrowly elliptical with rostrate poles (overall, the shape is therefore 'lanceolate'), $20.5-25.5 \times 6.25-6.5 \mu \mathrm{m}$. Striae radiate and slightly curved over most of the valve, becoming slightly convergent near the poles, sometimes with a few intercalated short striae at the centre, 24.3-25.7-28.2 in $10 \mu \mathrm{m}$; areolae invisible in LM. Axial area narrow. Central area expanded (to $55-65 \%$ of the valve width), \pm well-defined, bowtie-shaped. Raphe-sternum narrow, bordered externally by narrow but prominent grooves, which are discontinuous across the central area. Raphe very slightly sinuous. Polar bars present, parallel or slightly convergent.

Remarks: The consistently neat bow-tie-shaped central area and narrower poles seem to separate this from $\Phi$ 'slender'.

\section{Sellaphora [pupula K-LB] Ф 'amor' (Fig. 27)}

Valves linear-elliptical, with broad, slightly rostrate poles, $22-36.5 \times 7.75-8.5 \mu \mathrm{m}$. Striae radiate, curved near the centre, angled near the poles, with some intercalated short striae at the centre, 21.2-22.0-22.5 in $10 \mu \mathrm{m}$; areolae invisible in LM. Axial area narrow. Central area expanded (to 50$65 \%$ of the valve width), \pm well-defined, mostly bow-tie-shaped. No obvious groove alongside the raphe-sternum. Raphe slightly sinuous. Polar bars present, parallel.

Remarks: A specimen illustrated by LANGe-Bertalot \& Metzeltin (1996, pl. 82, fig. 6) from the Mittersee, Austria, may represent the same phenodeme. 

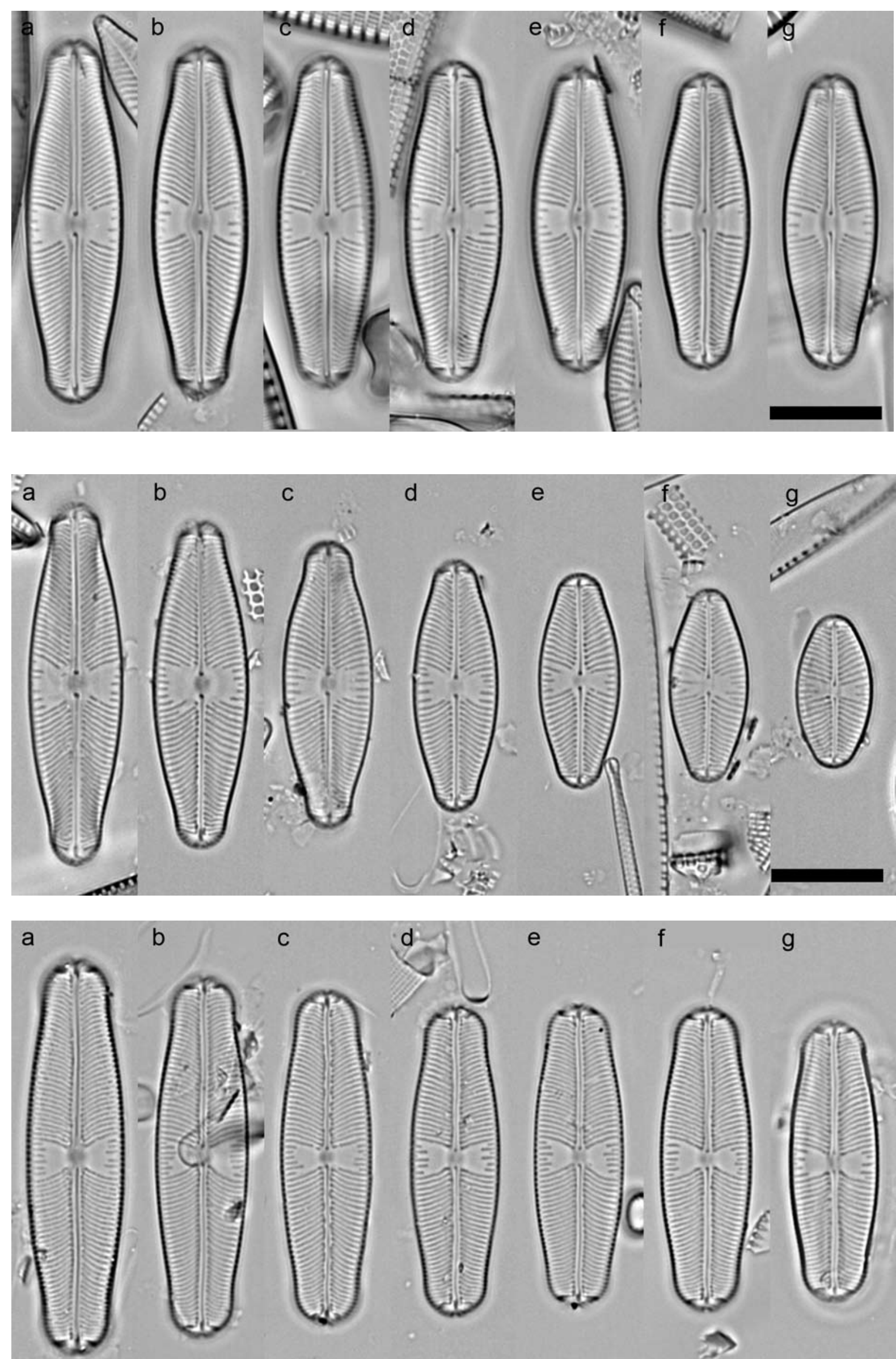

de
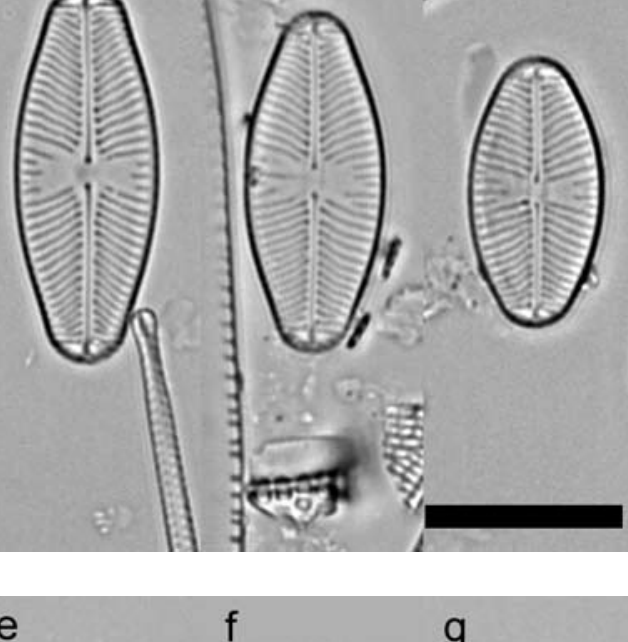

f $g$
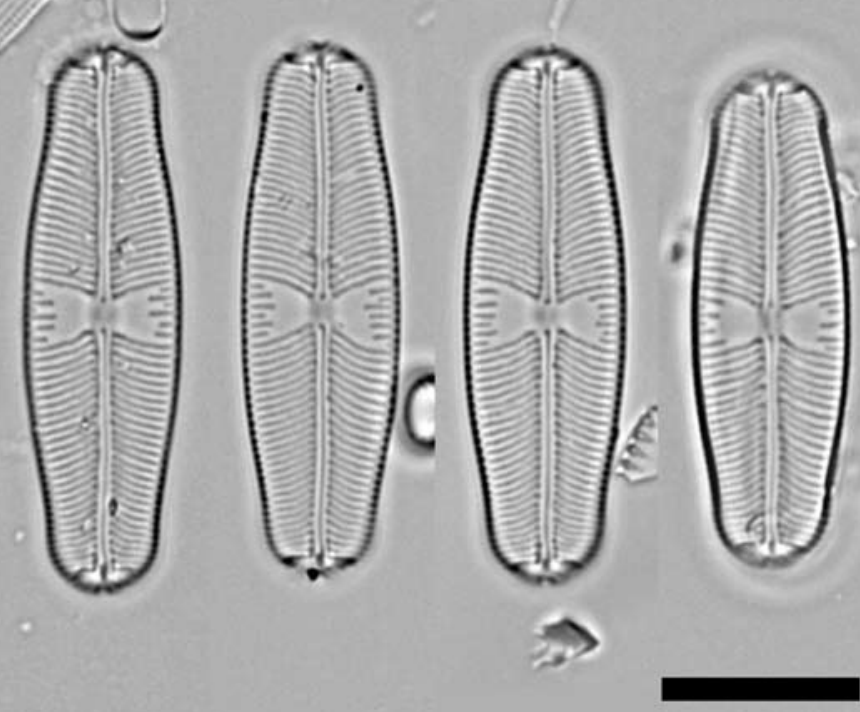


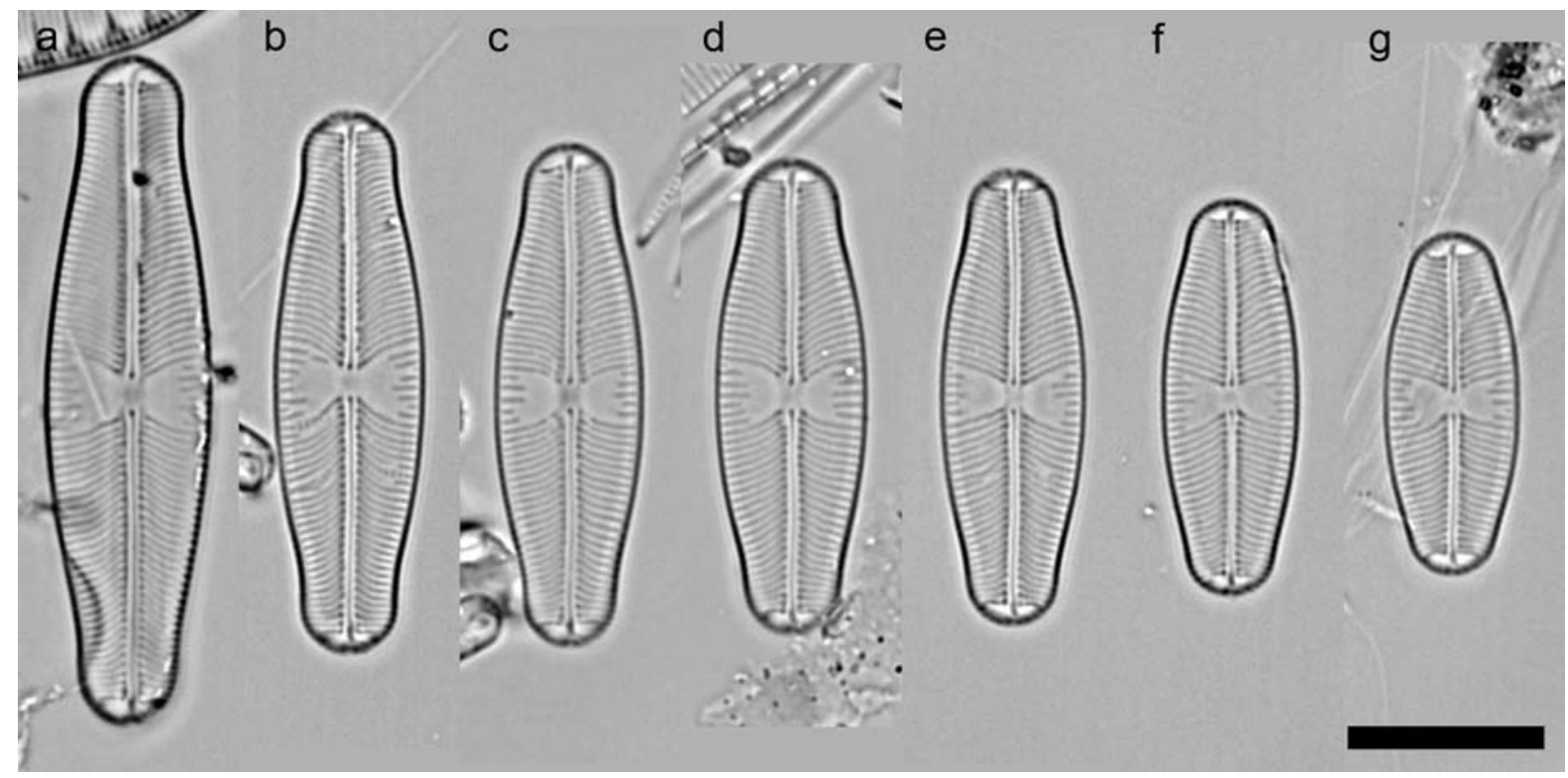

Fig. 24. Sellaphora [pupula K-LB] $\Phi$ 'tidy': Threipmuir Reservoir; (a-d) slide 'Threipmuir Marsh Basin usual 11.6.86 B (thin)'; (e-g) slide ‘Threipmuir Middle Basin NW end/coffer dam 11.6.86 C'. Scale bar $=10 \mu \mathrm{m}$.

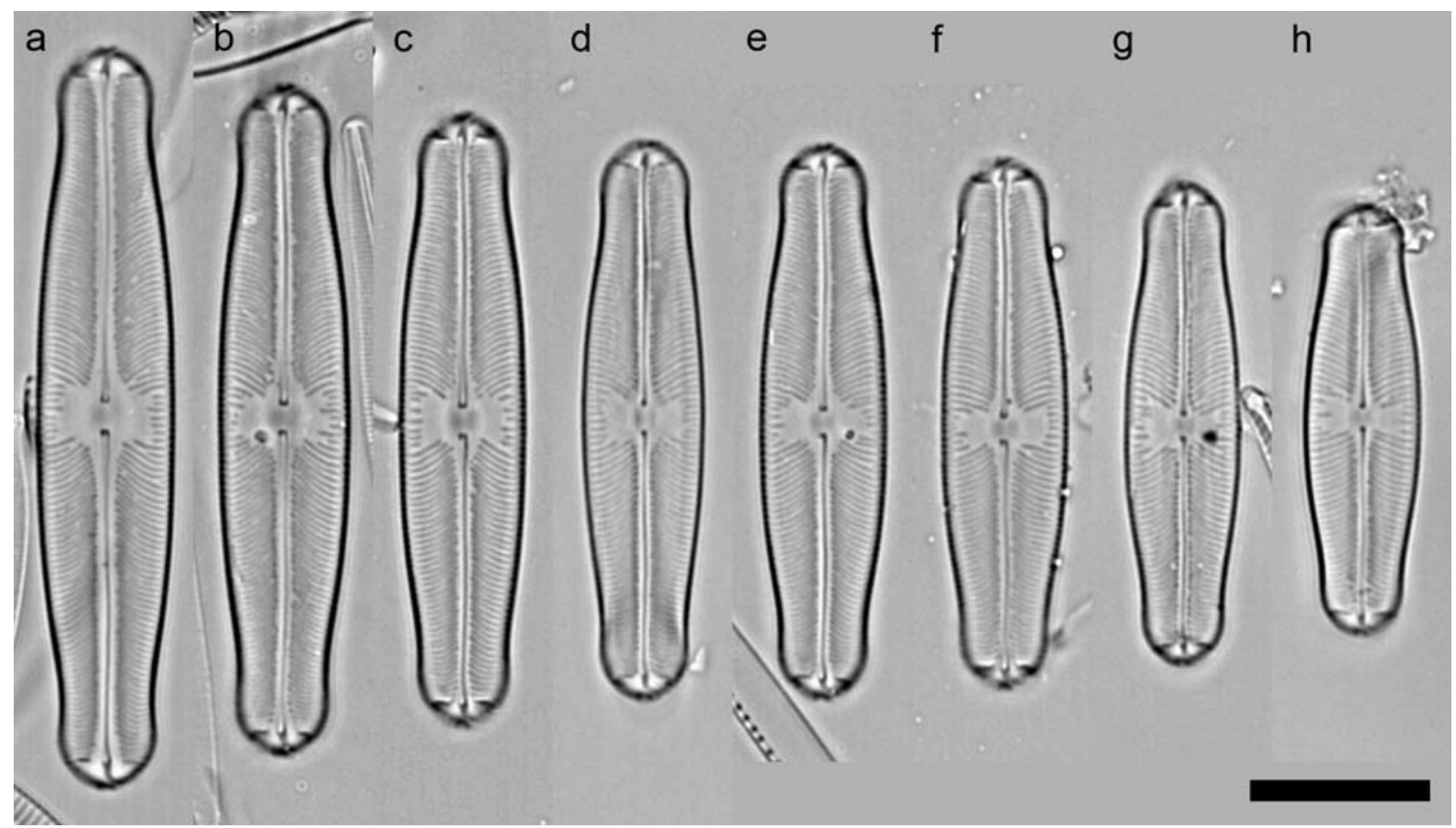

Fig. 25. Sellaphora [pupula K-LB] $\Phi$ 'slender': (a-c, e, f) Heart Moss, slide E423/1; (d, g, h) Loch of Craiglush, slide E323/2. Scale bar $=10 \mu \mathrm{m}$.

Fig. 21. Sellaphora [pupula K-LB] $\Phi$ 'meso-obese': (a, d) Crose Mere, slide E336/3; (b, c, e-g) Loch Leven, slide E3690/3. Scale bar $=10 \mu \mathrm{m}$.

Fig. 22. Sellaphora [pupula K-LB] $\Phi$ 'mini-obese': (a-c, f, g) Hanmer Mere, slide E334/2; (d, e) Cole Mere, E339/3. Scale bar $=10 \mu \mathrm{m}$.

Fig. 23. Sellaphora [pupula K-LB] $\Phi$ ‘wide tidy’: Loch Maree; (a-e, g) slide E2749.1; (f) slide E2763.1. Scale bar = $10 \mu \mathrm{m}$. 


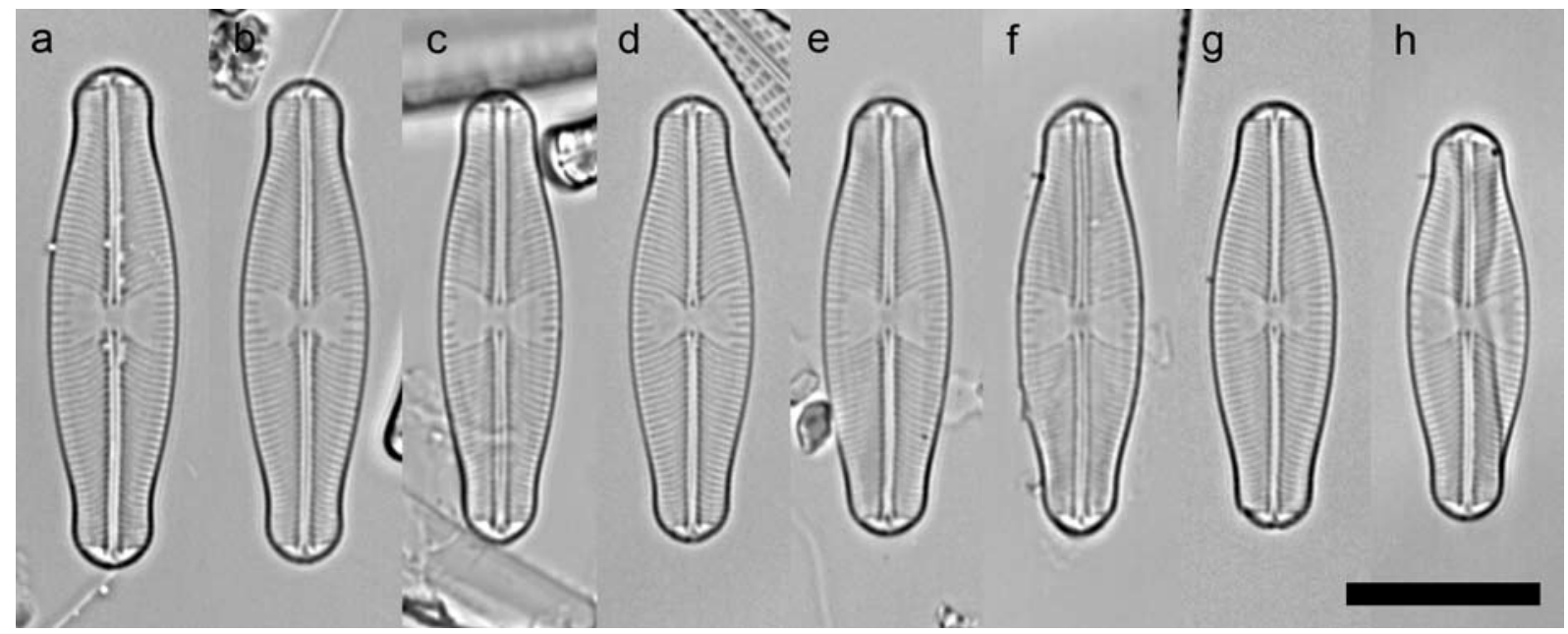

Fig. 26. Sellaphora [pupula K-LB] $\Phi$ 'refined': Threipmuir Reservoir; (a, b, e) slide 'Threipmuir Marsh Basin usual 11.6.86 B (thin)'; (c, f, h) slide 'Threipmuir usual 29.9.86 B'; (d, g) slide 'Threipmuir Middle Basin NW end/coffer dam 11.6.86 C'. Scale bar $=10 \mu \mathrm{m}$.

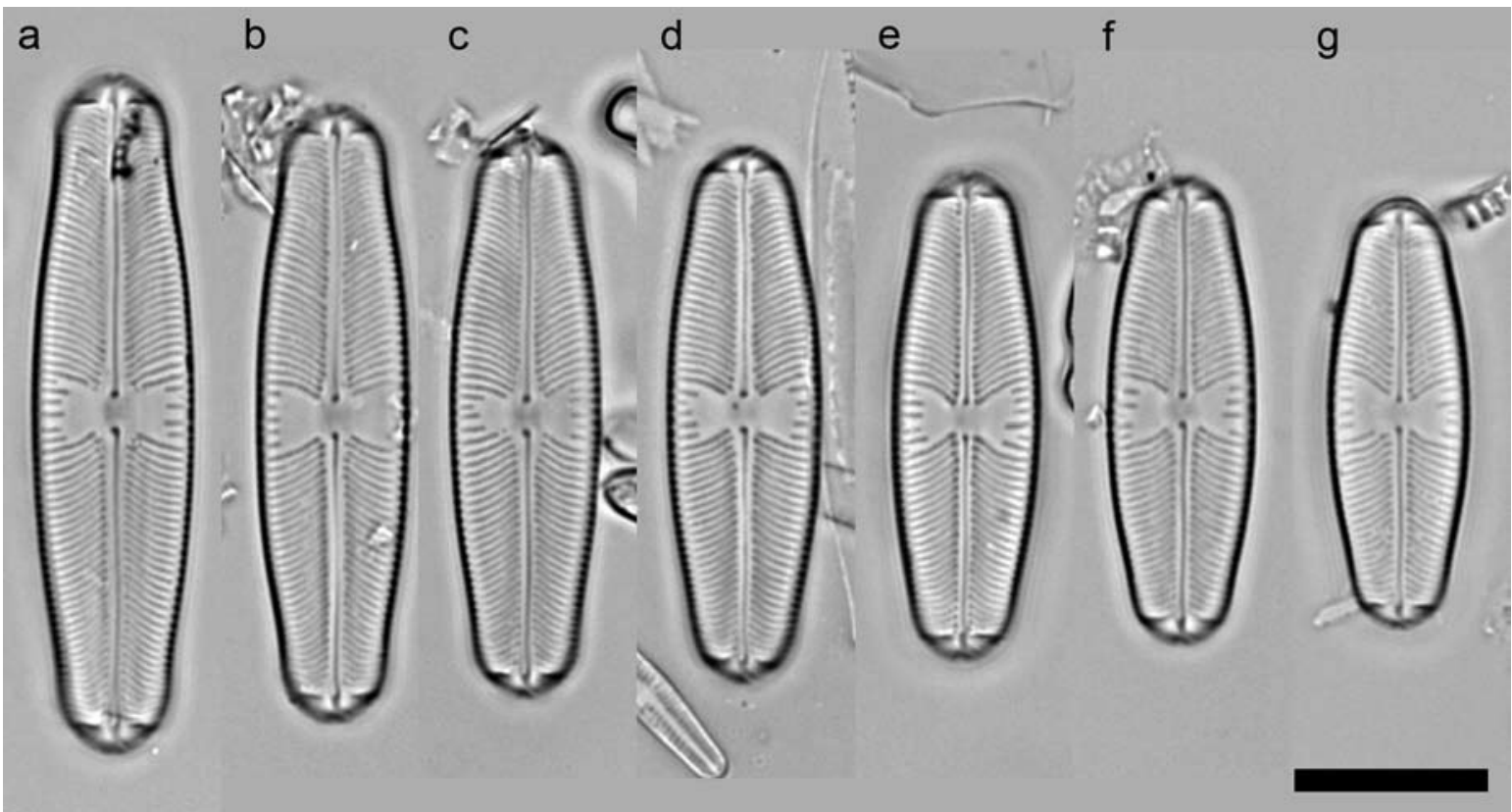

Fig. 27. Sellaphora [pupula K-LB] $\Phi$ 'amor': (a, c, e) Loch of Craiglush, slide E323/2; (b, f, g) Loch of Butterstone, slide E327/3; (d) Heart Moss, slide E423/1. Scale bar $=10 \mu \mathrm{m}$.

Sellaphora [pupula K-LB] $\boldsymbol{\Phi}$ 'perfidy' (Fig. present, parallel or very slightly convergent.

\section{8)}

Valves almost linear, with broadly rostrate poles, $22-33 \times 6.5-6.75 \mu \mathrm{m}$. Striae strongly radiate near the centre, becoming parallel or slightly convergent near the poles, straight or slightly curved and sometimes angled near the poles, sometimes with a few intercalated shorter striae at the centre, 20.5-21.5-22.5 in $10 \mu \mathrm{m}$; areolae just visible in LM. Axial area narrow. Central area very strongly expanded (to $65-80 \%$ of the valve width), \pm well-defined, bow-tie-shaped, sometimes almost a fascia. No obvious groove alongside the raphesternum. Raphe very slightly sinuous. Polar bars
REMARKs: This deme is similar to $S$. pseudopupula in valve dimensions, valve shape and stria pattern. Type material (from Kassel, Germany) was studied by Lange-Bertalot et al. (1996), confirming Krasske's (1923) protologue, which gives dimensions of 26-40 $\times 6-8 \mu \mathrm{m}$. However, the valves of the type population illustrated by LANGe-BERTALOT et al. (1996, pl. 18, figs $35-37)$ have c. 24 striae in $10 \mu \mathrm{m}$, which is significantly greater than in $\Phi$ 'perfidy'. Another diatom with similar shape and stria pattern was illustrated by Lange-Bertalot \& Metzeltin (1996, pl. 81, fig. 20); this also has higher striation density (26 in $10 \mu \mathrm{m})$. WERUM \& LANGE-BERTALOT (2004) illustrated four frus- 
tules identified as S. pseudopupula from spring communities on Triassic sandstone in the Spessart mountains, Germany (our samples were from a mesotrophic mire). Of the four specimens, one (pl. 31, fig. 26) is much smaller than $\Phi$ 'perfidy' (only $18 \times 5 \mu \mathrm{m}$ ) and cannot be assigned to the same deme, but the other three (pl. 31, figs 27-29) agree well with $\Phi$ 'perfidy' in valve dimensions $(25-31 \times 6.5-7.25)$ and stria density (c. 21 in $10 \mu \mathrm{m}$ ). The narrow form (pl. 31, fig. 26) may be the same as specimens identified as "Sellaphora aff. pseudopupula" by Metzeltin et al. (2005, pl. 65, figs 11-17). However, Metzeltin et al. (2005) doubted whether their specimens could be conspecific with $S$. pseudopupula because of the ecological differences between the Río de la Plata, near Colonia del Sacramento, Uruguay - said to be "meso-eutrophic" - and the typical habitats of $S$. pseudopupula, which are said to be "strictly electrolyte-poor, moderately acidic, and oligotrophic waters" (ibid., p. 209). LEVKOV et al. (2007) also record "S. pseudopupula", but again there are significant discrepancies between their material and the type, since the valves illustrated (pl. 107, figs 23,24$)$ have only c. 19 striae in $10 \mu \mathrm{m}$. RuMrICH et al. (2000, pl. 68, fig. 18) illustrate a diatom from a stream on the Chilean Altiplano that they assign to $S$. pseudopupula, but the simple elliptical outline of this specimen agrees better with our $\Phi$ 'upland elliptical'. A better fit to $S$. pseudopupula and $\Phi$ 'perfidy' is their fig. 20 ("Sellaphora spec. cf. pupula") from a rill at $4000 \mathrm{~m}$ altitude in Venezuela. Finally, Schomman \& ARCHIBALD (1976-1980, figs 66-74) have illustrated a deme from Lesotho that is reminiscent of $\Phi$ 'perfidy' in its linear outline and stria pattern. However, there is a clear difference between these demes in stria density (at c. 30 striae in $10 \mu \mathrm{m}$, the Lesotho specimens are more finely striated than any other [pupula] deme we have encountered) and in the poles, which are not rostrate but simply rounded in the Lesotho material. The 'pseudopupula group' needs much further study.

\section{Sellaphora [pupula K-LB] Ф 'pointy' (Fig. 29)}

Valves rhombic-elliptical, becoming narrow elliptical, with rounded or subacute broadly rostrate poles, $19.5-33.5 \times 6.5-7.0 \mu \mathrm{m}$. Striae radiate, straight or slightly curved, sometimes with a few intercalated short striae at the centre, 21.9- 23.525.7 in $10 \mu \mathrm{m}$; areolae scarcely visible in LM. Axial area narrow. Central area strongly expanded (to $65-75 \%$ of the valve width), bow-tie-shaped. Perhaps with a shallow groove externally alongside the raphe-sternum. Raphe very slightly sinuous. Polar bars present, parallel.

\section{Sellaphora pupula (Fig. 30)}

Valves narrowly elliptical, with broadly rostrate poles (overall, the shape is therefore 'lanceolate'), 16-34 $(35) \times 6.0-7.75 \mu \mathrm{m}$. Striae radiate and \pm straight near the centre, becoming parallel or slightly convergent close to the polar bars, with some intercalated short striae at the centre, (21.3) 22.6-23.9-25.0 (25.6) in $10 \mu \mathrm{m}$; areolae invisible in LM. Axial area narrow. Central area strongly expanded (to $60-70 \%$ of the valve width), transversely rectangular. No obvious groove alongside the raphe-sternum. Raphe very slightly sinuous. Polar bars present, parallel to slightly convergent.

Remarks: LeVkov et al. (2007, pl. 107, figs "20-21", but three valves are shown) illustrate diatoms resembling $S$. pupula in shape, dimensions and stria pattern, but the stria density is lower (c. 20-21 in $10 \mu \mathrm{m}$ ). Some other possible records are discussed by MANN (2001).

\section{Sellaphora [pupula K-LB] Ф 'mouse' (Fig. 31)} Valves narrowly elliptical, with rostrate poles (overall, the shape is therefore 'lanceolate'), $22.5-35.5 \times 6.75-7.75 \mu \mathrm{m}$. Striae radiate and slightly curved over most of the valve, sometimes angled and becoming parallel close to the polar bars, sometimes with a few intercalated short striae at the centre, 19.9-21.3-23.0 in $10 \mu \mathrm{m}$; areolae invisible in LM. Axial area very narrow. Central area expanded (to $50-70 \%$ of the valve width), transversely rectangular to \pm elliptical. No obvious groove alongside the raphe-sternum. Raphe very slightly sinuous. Polar bars present, parallel to slightly convergent.

Remarks: Metzeltin \& Lange-Bertalot (2002, pl. 32, figs 7,8$)$ illustrate diatoms from the Zambesi River, Zimbabwe, that could be identified as $\Phi$ 'mouse'. $\Phi$ 'mouse' and $S$. pupula are separated principally by the narrower width of the poles and lower stria density in $\Phi$ 'mouse', but the two may intergrade.

\section{Sellaphora [pupula K-LB] $\Phi$ 'little' (Fig. 32)}

Valves narrowly elliptical with broadly rostrate poles, $21-28.5 \times 7.0-7.25 \mu \mathrm{m}$. Striae curved, radiate, becoming parallel or convergent near the poles, with some intercalated short striae at the centre, 18.7-19.8-20.9 in $10 \mu \mathrm{m}$; areolae invisible in LM. Axial area very narrow. Central area strongly expanded (to $55-80 \%$ of the valve width), somewhat irregular, \pm bow-tie-shaped. No obvious groove alongside the raphe-sternum. Raphe very slightly sinuous. Polar bars present, slightly convergent. DNA BARCodE (COX1): GenBank EF164928. 

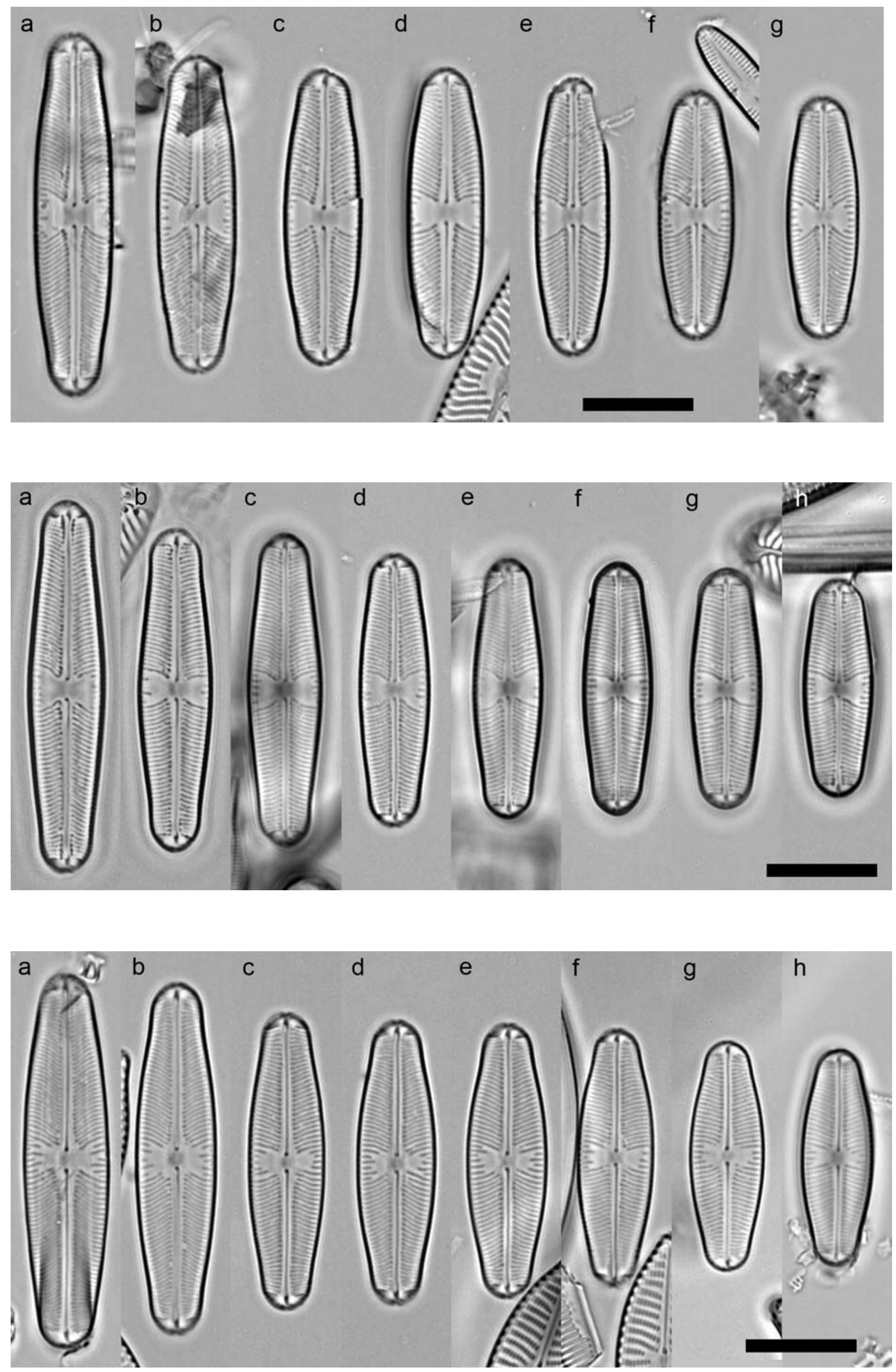


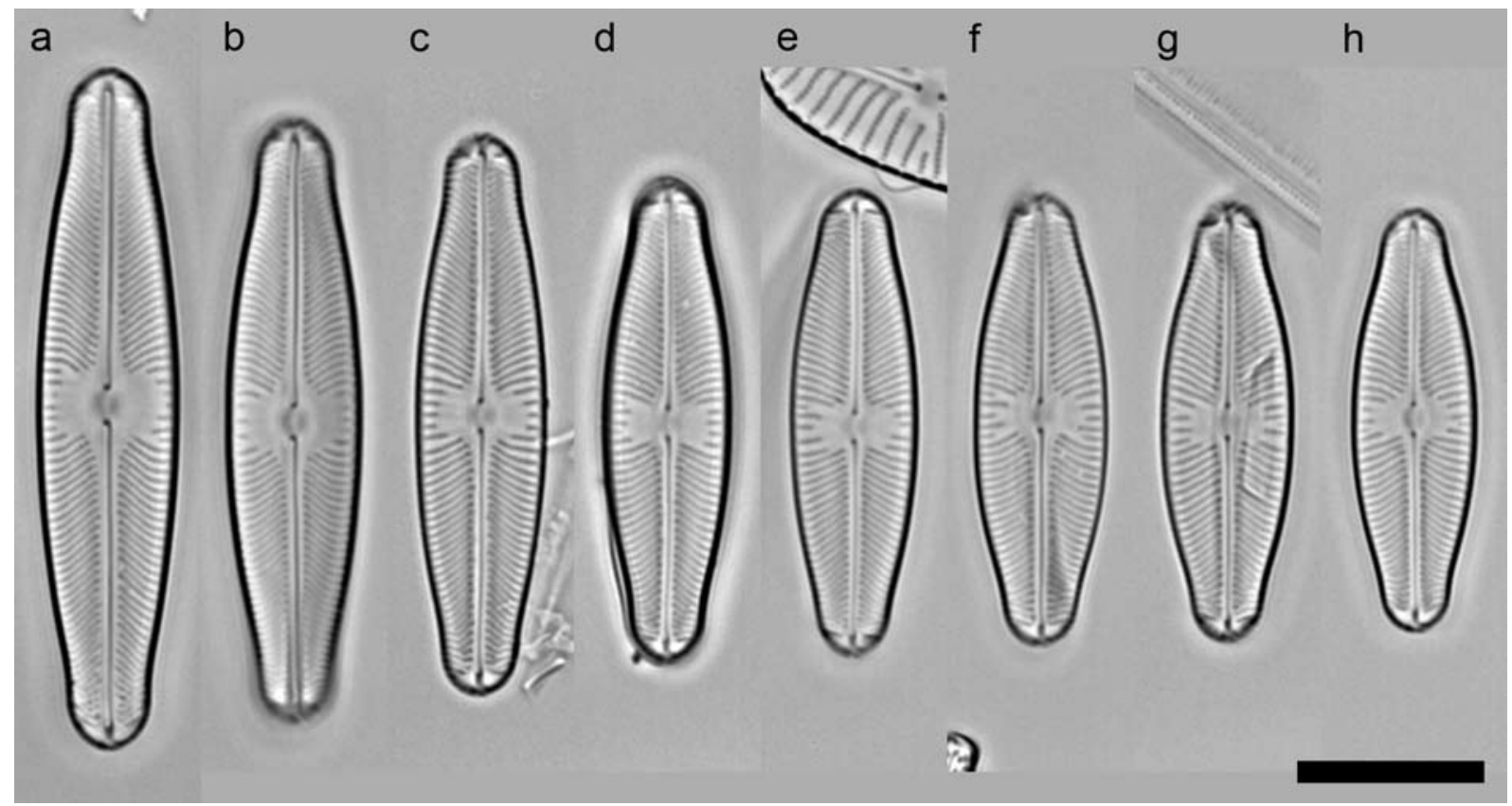

Fig. 31. Sellaphora [pupula K-LB] $\Phi$ 'mouse': Loch Leven; (a, c-e) slide E3690/3; (b, f-h) slide E3830/3. Scale bar = 10 $\mu \mathrm{m}$.

Fig. 28. Sellaphora [pupula K-LB] $\Phi$ 'perfidy': mire near Threipmuir Reservoir; (a-g) slide 'NE Threipmuir Acrocladium ... sample 7, 2.4.81, slide 2'. Scale bar $=10 \mu \mathrm{m}$.

Fig. 29. Sellaphora [pupula K-LB] $\Phi$ 'pointy': Loch Tulla; $(\mathrm{a}-\mathrm{h})$ slide E3747/2. Scale bar $=10 \mu \mathrm{m}$.

Fig. 30. Sellaphora pupula: (a) Inverleith Pond, slide E319/2; (b-g) Blackford Pond, slide E16 'Stand'; (h) Dunsapie Loch, E3572. Scale bar $=10 \mu \mathrm{m}$.

\section{Sellaphora pupula [K-LB] $\Phi$ 'spindle' (Fig.} 33)

Valves narrowly elliptical with rostrate (sometimes slightly capitate) poles, $20-29 \times 6.25-8 \mu \mathrm{m}$. Striae straight or slightly curved, radiate, becoming parallel and sometimes angled near the poles, with some intercalated short striae at the centre, 18.9-20.7-21.7 in $10 \mu \mathrm{m}$; areolae invisible in LM (here and elsewhere in Sellaphora, striae can sometimes appear dotted when some areolae are missing: Fig. 33c). Axial area very narrow. Central area very strongly expanded (to $70-80 \%$ of the valve width), \pm well-defined, bow-tie-shaped. No obvious groove alongside the raphe-sternum. Raphe very slightly sinuous. Polar bars present, parallel or slightly convergent (in long specimens). DNA BARCODE (COX1): GenBank EF164951.

Remarks: $\Phi$ 'spindle is similar to $S$. paenepupula (Metzeltin \& Lange-Bertalot 2002, p. 66, pl. 31, figs 9-15) in shape and stria pattern but is slightly larger and more coarsely striated (c. 21, rather than 23-24 in $10 \mu \mathrm{m})$. Sellaphora paenepupula was described from the River Ivato, Madagascar, and Metzeltin \& Lange-
BERTALOT stated that they had not observed the species in other parts of the world.

\section{Sellaphora auldreekie (Fig. 34)}

Valves narrowly elliptical to elliptical with strongly rostrate (sometimes slightly capitate) poles, (15) 17.5-28 (35) × 6.5-7.75 (8) $\mu \mathrm{m}$. Striae slightly curved, radiate, becoming parallel and sometimes angled near the poles, with some intercalated short striae at the centre, (19) 20.5-21.7-23.5 (24) in 10 $\mu \mathrm{m}$; areolae invisible in LM. Axial area very narrow. Central area strongly expanded (to $60-70 \%$ of the valve width), \pm well-defined, bow-tie-shaped. No obvious groove alongside the raphe-sternum. Raphe \pm straight. Polar bars present, parallel or slightly convergent (in long specimens). DNA BARCODE (COX1): GenBank EF164932.

Remarks: Like $\Phi$ 'spindle, $S$. auldreekie resembles $S$. paenepupula (Metzeltin \& Lange-Bertalot 2002, p. 66 , pl. 31, figs 9-15), but it differs in having narrower and more rounded poles. It is usually more coarsely striated and the larger type specimens of S. paenepupula illustrated by Metzeltin \& LANGe-Bertalot (their 
figs 13-15) are almost parallel-sided at the centre (contrast our Fig. 34). More similar to $S$. auldreekie than the type specimens of $S$. paenepupula are three valves identified as $S$. paenepupula from the Río de la Plata near Colonia del Sacramento, Uruguay (Metzeltin et al. 2005, pl. 64, figs 28-30); the poles are of \pm equal size and the central area is a wide 'bow-tie'. Sellaphora rostrata, based on HuSTEDT's (1911) var. rostrata from near Bremerhaven and typified by SIMONSEN (1987, pl. 5, figs 5-7), is a narrower diatom with a transversely rectangular central area. However, the distinctions between $S$. rostrata, $S$. auldreekie, and the even smaller and more finely striated $\Phi$ 'tiny' need further study.

\section{Sellaphora [pupula K-LB] Ф 'tiny' (Fig. 35)}

Valves narrowly elliptical to elliptical with strongly rostrate (sometimes slightly capitate) poles, 12.5-23 × 5.5-6.75 $\mu \mathrm{m}$. Striae slightly curved, radiate, becoming parallel and sometimes angled near the poles, with some intercalated short striae at the centre, 22.5-23.9-25.7 in $10 \mu \mathrm{m}$; areolae invisible in LM. Axial area very narrow. Central area expanded (to $55-65 \%$ of the valve width), somewhat irregular, \pm bow-tie-shaped to transversely rectangular. Raphe-sternum possibly bordered by a shallow groove. Raphe straight. Polar bars present, parallel or slightly convergent (in long specimens).

REMARKs: See comments under S. auldreekie.

\section{Sellaphora [pupula K-LB] $\Phi$ 'urban elliptical'} (Fig. 36)

Valves linear-elliptical, with slightly rostrate poles, $20.5-47 \times 6.75-9.0 \mu \mathrm{m}$. Striae straight, radiate to almost parallel centrally, becoming parallel or slightly curved near the poles, sometimes with a few intercalated short striae at the centre, 18.5-20.4-21.5 in $10 \mu \mathrm{m}$; areolae visible in LM. Axial area narrow. Central area strongly expanded (to $60-80 \%$ of the valve width), transversely rectangular. A shallow groove present externally alongside the raphe-sternum. Raphe slightly sinuous. Polar bars present, parallel, sometimes slightly radiate in longer specimens. DNA BARCODE (COX1): GenBank EF164944.

REMARKS: For this deme and the next, the names were chosen because of the valve shape, especially in cells towards the end of size reduction. No link is implied with either Navicula pupula var. elliptica (HuSTEDT 1911 , for which a type was selected and illustrated by SiMONSEN 1987, pl. 5, figs 3, 4) or Sellaphora elliptica (MERESCHKOWSKY 1902).

\section{Sellaphora [pupula K-LB] $\Phi$ 'upland elliptical'} (Fig. 37)

Valves linear-elliptical to elliptical, with very slightly rostrate or evenly curved poles, 17-39.5 $\times 6.5-8 \mu \mathrm{m}$. Striae straight, radiate to almost parallel centrally, becoming parallel near the poles, sometimes with a few intercalated short striae at the centre, $18.8-20.5-21.9$ in $10 \mu \mathrm{m}$; areolae visible in LM. Axial area narrow. Central area expanded (to $50-75 \%$ of the valve width), transversely rectangular. A shallow groove present externally alongside the raphe-sternum. Raphe slightly sinuous. Polar bars present, parallel. DNA BARCODE (COX1): GenBank EF164952.

REMARKs: Many records of 'Navicula pupula var. elliptica' probably refer to this phenodeme, because of the drawings provided by HuSTEDT (1930, fig. 467d; 1961, fig. $1254 \mathrm{~h}$, as f. elliptica), but it does not correspond to the type selected by SimONSEN 1987, pl. 5, figs 3, 4).

\section{Sellaphora [pupula K-LB] $\Phi$ 'europa' (Fig. 38)}

Valves linear-elliptical, with broad subcapitate to rostrate poles, $16-36.5 \times 6.75-7.75 \mu \mathrm{m}$. Striae slightly radiate, straight or very slightly curved, with some intercalated short striae at the centre, 20.1-21.0-22.6 in $10 \mu \mathrm{m}$; areolae visible with difficulty in LM. Axial area narrow. Central area strongly expanded (to $60-80 \%$ of the valve width), somewhat irregular, \pm bow-tie-shaped or transversely rectangular. Perhaps with a shallow groove externally alongside the raphe-sternum. Raphe slightly sinuous. Polar bars present, parallel to slightly radiate. DNA BARCODE (COX1): GenBank EF164955.

\section{Sellaphora [pupula K-LB] $\Phi$ 'small blunt-cap- itate' (Fig. 39)}

Valves almost linear, becoming linear-elliptical, with broadly rostrate or subcapitate poles, 19-32.5 $\times 6.25-7.25 \mu \mathrm{m}$. Striae slightly radiate, straight or slightly curved, usually with some intercalated short striae at the centre, 20.9-22.8-24.3 (Loch Maree) and 21.2-23.2-25.5 (Loch Achray) in 10 $\mu \mathrm{m}$; areolae scarcely visible in LM. Axial area narrow. Central area expanded (to $50-70 \%$ of the valve width), transversely rectangular to bow-tieshaped. Perhaps with a shallow groove externally alongside the raphe-sternum. Raphe slightly sinuous. Polar bars present, parallel.

REMARKS: Oligotrophic and dystrophic waters often contain small [pupula] specimens with c. 23 striae in 


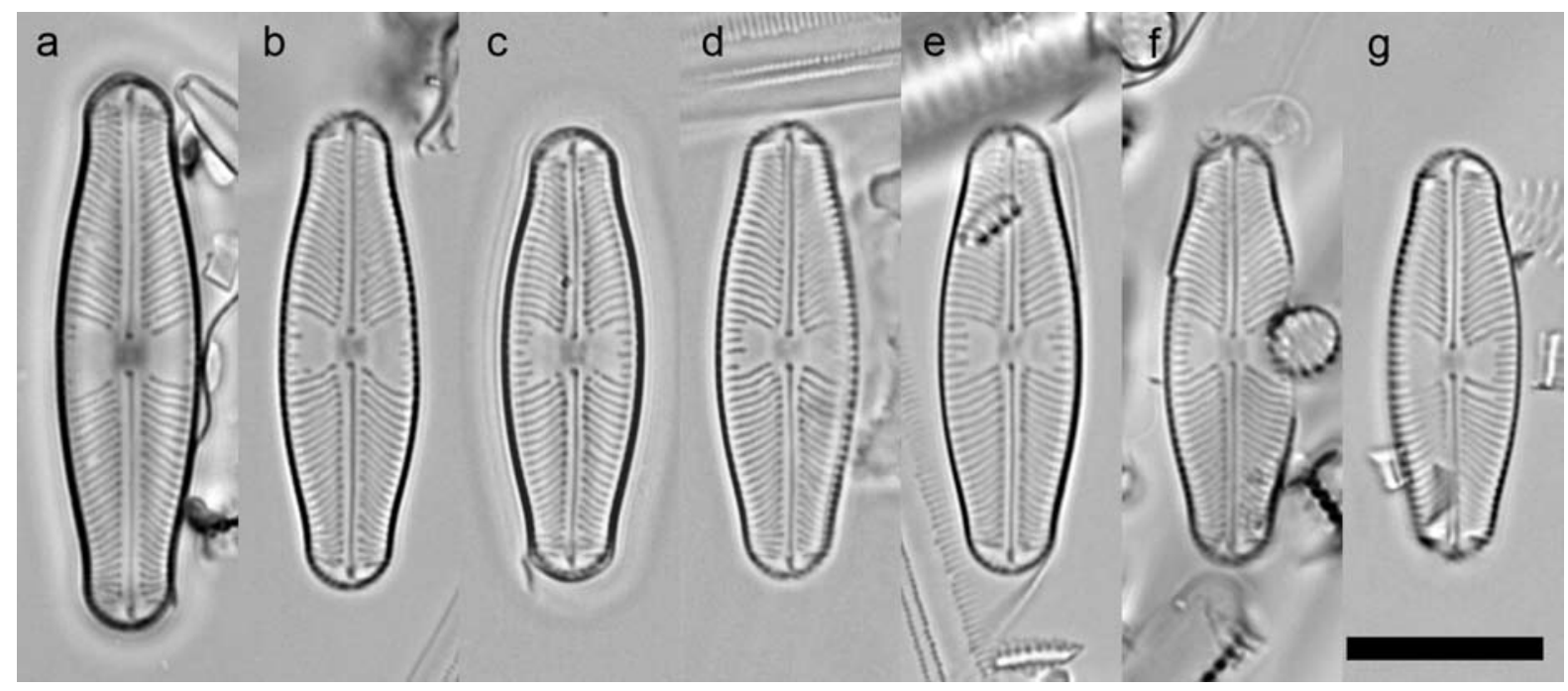

Fig. 32. Sellaphora [pupula K-LB] $\Phi$ 'little': Royal Botanic Garden Edinburgh pond; (a, g) slide E2614/3; (b, d-f) slide $\mathrm{E} 2614 / 3$; (c) slide E3699/2. Scale bar $=10 \mu \mathrm{m}$.

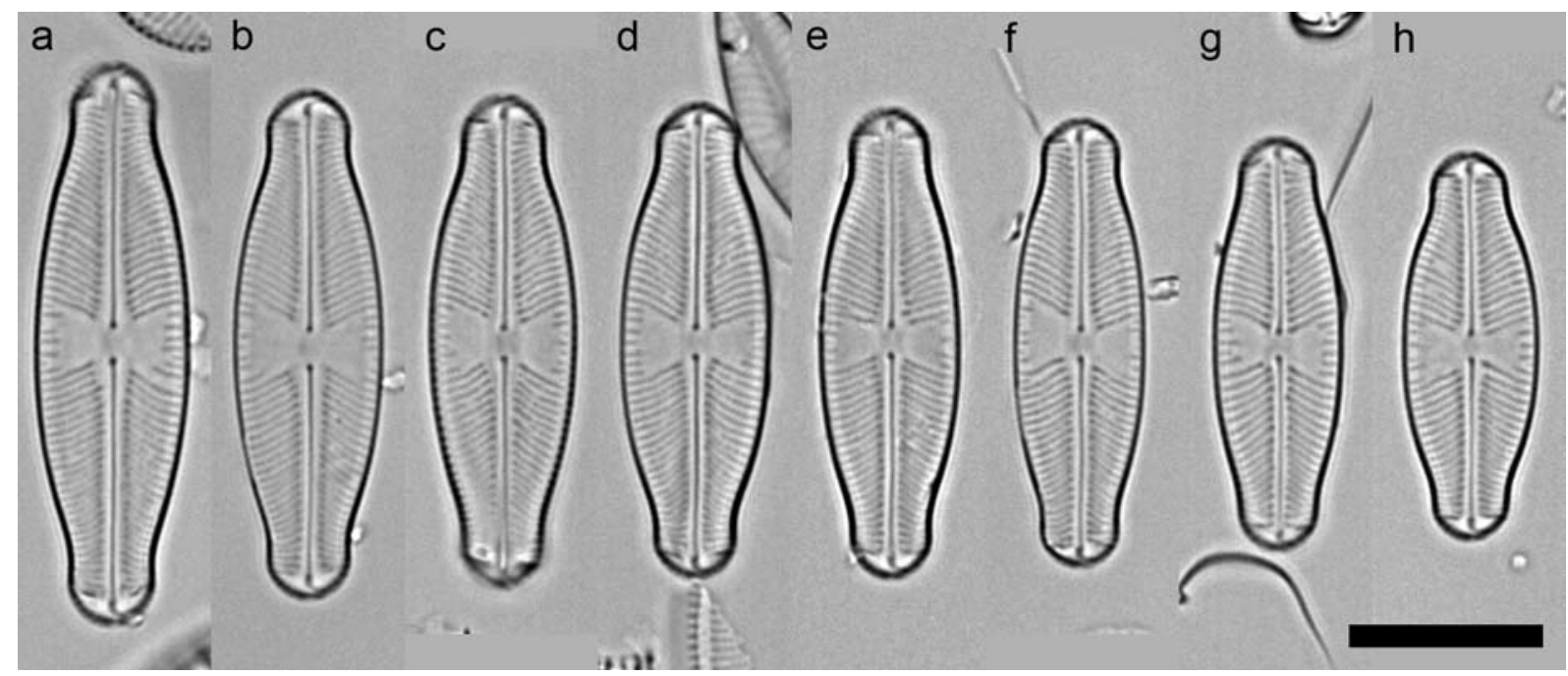

Fig. 33. Sellaphora pupula [K-LB] $\Phi$ 'spindle': Blackford Pond; (a-h) slide E2004/2; In (c), some striae appear punctate because of missing areolae. Scale bar $=10 \mu \mathrm{m}$.

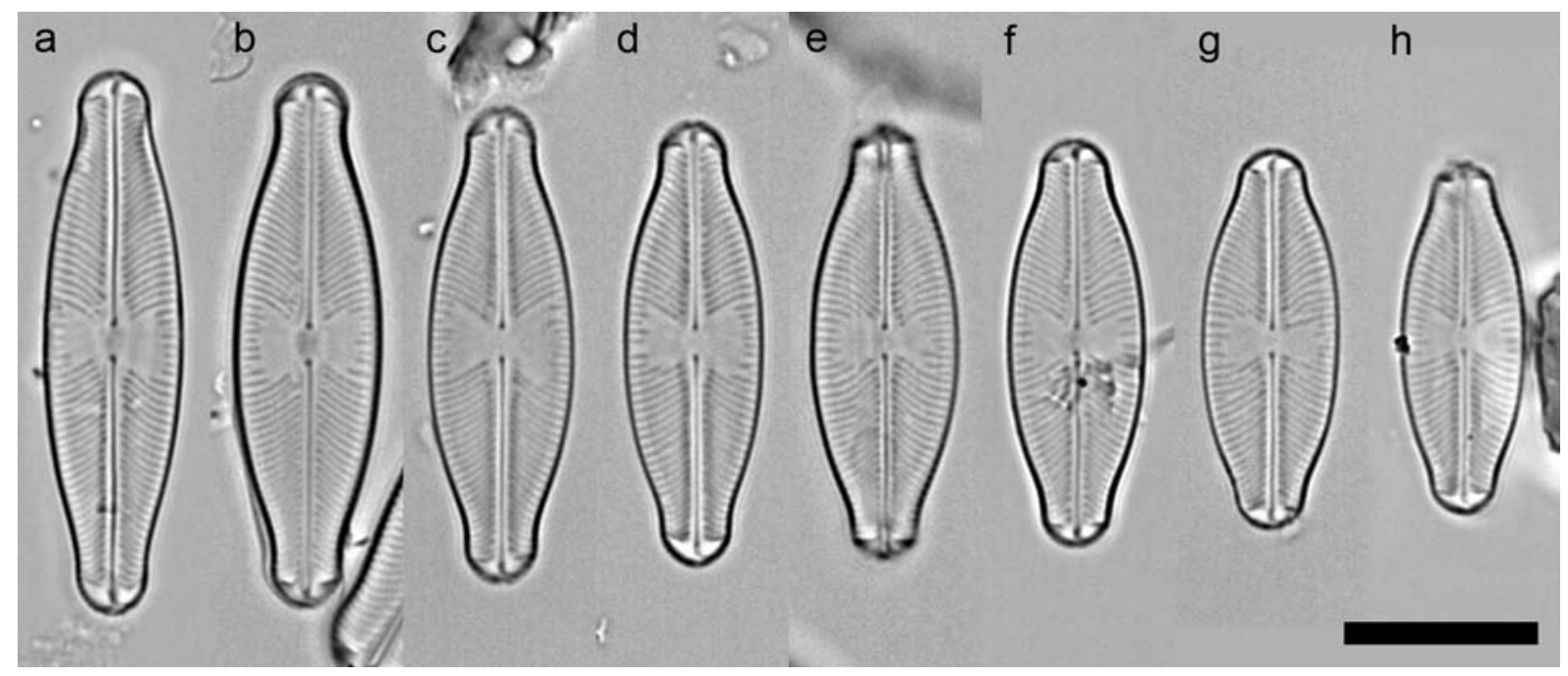

Fig. 34. Sellaphora auldreekie: (a, f, h) Dunsapie Loch, slide E3572; (b-e, g) Blackford Pond, slide E2004/2. Scale bar = 10 $\mu \mathrm{m}$. 
$10 \mu \mathrm{m}$ that vary in shape from linear or linear-elliptical (like those shown here: Fig. 39) to linear-rhombic (like $\Phi$ 'pointy': Fig. 29) and may or may not have subcapitate or rostrate poles.

\section{Sellaphora [pupula K-LB] Ф 'gross' (Fig. 40)}

Valves linear-elliptical, with broad, subcapitate poles (becoming rostrate in the smallest specimens), 33-41.5 × 10.0-10.75 $\mu \mathrm{m}$. Striae radiate and curved, becoming parallel towards the poles, with some intercalated short striae at the centre, 17.8-19.0-20.4 in $10 \mu \mathrm{m}$; areolae invisible in LM. Axial area narrow. Central area expanded (to c. $55-65 \%$ of the valve width), somewhat irregular, transversely rectangular to bow-tie-shaped. Raphe-sternum well-defined, through development of very prominent grooves alongside it externally. Raphe sinuous. Polar bars present, parallel or slightly radiate.

REMARKS: This deme is very similar to illustrations of $S$. parapupula from the Mittersee, Austria, provided by Lange-Bertalot \& Metzeltin (1996, pl. 82, figs 1-3). Their specimens are longer than those recorded here, being $57.7 \times 11.7,53.4 \times 11.7$ and $41.4 \times 11.0 \mu \mathrm{m}$, but the trend in valve width with length corresponds reasonably well to that in our material. Sellaphora parapupula was based on the diatom originally described by HuSTEDT (1930) as Navicula pupula var. capitata Hust., which was illegitimate because of the earlier var. capitata SkVORTzow \& Meyer (1928). Simonsen's (1987, pl. 194, figs 6, 7) illustration of the type of Navicula pupula var. capitata Hust. shows a diatom very similar both to $\Phi$ 'gross' and $S$. parapupula sensu LANGe-Bertalot \& Metzeltin (1996), but until further information is available about variation within the type population HusTEDT collected from Henriksberg, Finland (the type slide contains only two picked specimens), identification as $S$. parapupula can only be said to be 'very likely'. Metzeltin \& LANGe-BertaLOT (2002, pl. 31, fig. 6) illustrated a further specimen (from Namorona, Madagascar) that they allocated to $S$. parapupula. This measures $64 \times 12.6 \mu \mathrm{m}$ (from the photograph) - somewhat wider than might be expected from variation within the Julma Ölkky material, and the striae appear more punctate; on the other hand, it possesses 19 striae in $10 \mu \mathrm{m}$ like the other populations. No information is available about variation within the
Madagascan material.

\section{Sellaphora [pupula K-LB] Ф 'large' (Fig. 41)}

Valves almost linear, becoming linear-elliptical, with subcapitate (in the longest specimens), broadly rostrate or smoothly rounded poles, $23.5-$ $49.5 \times 8.75-9.75 \mu \mathrm{m}$. Striae radiate and almost straight over the whole valve, except near the poles, where they become curved and sometimes parallel, with a few intercalated short striae at the centre, 17.5-19.3-21.4 in $10 \mu \mathrm{m}$; areolae visible in LM. Axial area narrow. Central area strongly expanded (to c. $60-70 \%$ of the valve width), transversely rectangular to bow-tie-shaped (in longer specimens). Raphe-sternum bordered externally by shallow grooves. Raphe slightly sinuous. Polar bars present, parallel or slightly radiate. DNA BARCODE (COX1): GenBank EF164945.

Remarks: Two valves with outline, stria pattern and stria density like that of $\Phi$ 'large', but perhaps slightly wider, were illustrated from a $19^{\text {th }}$ century sample from "Lough End" (= Lochend Loch, Edinburgh: Table 3), by Schoeman \& Archibald (1976-1980, figs 28, 29). We have looked for this diatom in new samples from Lochend, which now lies in a municipal park surrounded by houses, but it seems to have become locally extinct. There is no doubt that this phenodeme and the next are very similar indeed. However, the course of size reduction seems to differ in the two (Figs 41, 42) and $\Phi$ 'large' seems to be a less heavily silicified diatom (these two characters may be linked, since less flexibility of the girdle would constrain shape to remain more strictly linear, as in $\Phi$ 'cf. large').

\section{Sellaphora [pupula K-LB] $\Phi$ 'cf. large' (Fig. 42)}

Valves linear, with broadly rostrate poles, 31-46 $\times 8.5-9.5 \mu \mathrm{m}$. Striae radiate and curved over the whole valve, with a few intercalated short striae at the centre, 19.5-20.7-21.5 in $10 \mu \mathrm{m}$; areolae visible in LM. Axial area narrow. Central area expanded (to c. $50-70 \%$ of the valve width), \pm bowtie-shaped, sometimes transversely rectangular. Raphe-sternum bordered externally by prominent grooves. Raphe slightly sinuous. Polar bars

Fig. 35. Sellaphora [pupula K-LB] $\Phi$ 'tiny': Threipmuir Reservoir; (a, f-h) slide E2588/3; (b-e) slide 'Threipmuir usual 29.9.86 B'. Scale bar $=10 \mu \mathrm{m}$.

Fig. 36. Sellaphora [pupula K-LB] $\Phi$ 'urban elliptical': Blackford Pond; (a-c, e-g) slide E2004/2; (d) slide E3578/1. Scale bar $=10 \mu \mathrm{m}$.

Fig. 37. Sellaphora [pupula K-LB] $\Phi$ 'upland elliptical': Threipmuir Reservoir; (a, e) slide E2588/1; (b) slide 'Threipmuir usual 29.9.86 B'; (c, d) slide 'Threipmuir NE Basin sandy ... 11.6.86 A'; (f, g) slide 'Threipmuir Marsh Basin usual 11.6.86 B (thin)'. Scale bar $=10 \mu \mathrm{m}$. 

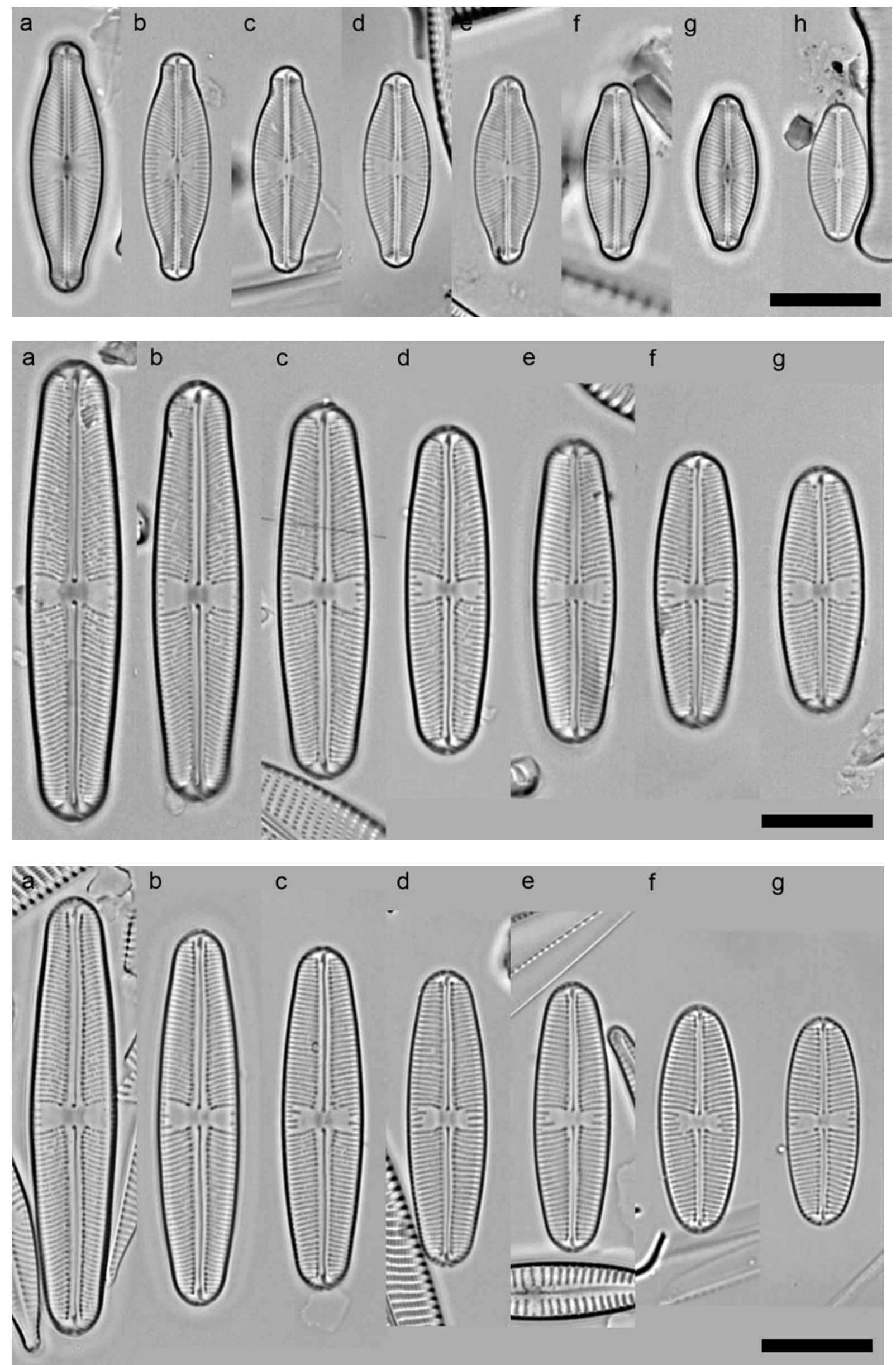

C
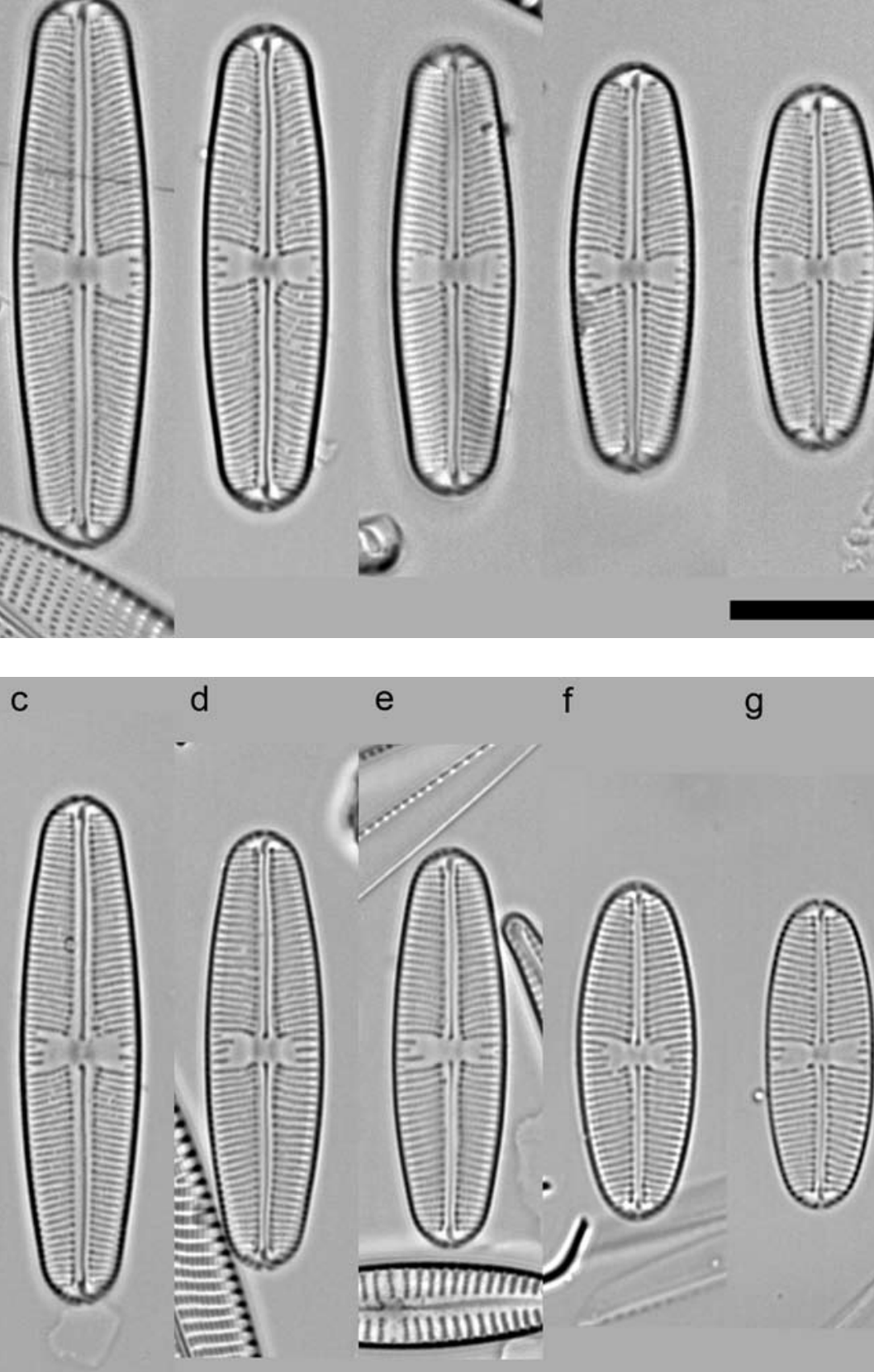
present, parallel or slightly radiate.

REMARKs: Three very similar, strictly linear valves from Lake Julma Ölkky, Finland, were illustrated by Lange-Bertalot \& Metzeltin (1996, pl. 25, figs 1012), who assigned them to "Sellaphora rectangularis (Greg.) Lange-Bertalot \& Metzeltin nov. comb.”. Their specimens measure $42.5 \times 9.2,46.4 \times 9.7$ and $56.4 \times 9.6 \mu \mathrm{m}$, with c. $19-21$ striae in $10 \mu \mathrm{m}$. Other very similar specimens have been illustrated by METzeltin \& Lange-Bertalot (1998, pl. 85, fig. 9) from the Demerara River, Guyana, and by Metzeltin \& LANGeBertalot (2002, pl. 31, figs 4, 5) from Ivato, Madagascar. However, the basionym was originally published as Stauroneis rectangularis by GREGORY (1854) and, although specimens from authenticated material were illustrated by SchoEman \& ARChiBALD (1976-1980) and were presumably referred to by LANGE-BERTALOT \& Metzeltin, these latter authors nevertheless noted (Lange-Bertalot \& Metzeltin 1996, p. 168; see also p. 103) that "Die Identität dieser Sippe mit dem Typus des Basionyms ist nicht völlig zweifelsfrei". We agree with them that the matter is unresolved. Unfortunately, authenticated material we have examined from Gregory's material (a Holocene diatomite on Mull, W Scotland) contains extremely few, poorly preserved specimens, as apparently did the slide of similar material studied by SchoEmAn \& ARChiBALd (1976-1980, figs 19-22). It will probably be necessary to add an epitype to establish the use of the name rectangularis.

LEVKov et al. (2007, pl. 107, fig. 25) illustrate a single valve identified as $S$. rectangularis from Lake Prespa. This valve is too narrow $(7.5 \mu \mathrm{m})$ to be assigned to $\Phi$ 'cf. large' or $\Phi$ 'large' and its identity is unclear. A series of valves identified by METzeLtin \& LANGe-BERтALOT (2007, pl. 157, figs 24-28) as "Sellaphora aff. rectangularis" document morphology and size reduction very well and show that assignment to the same phenodemes as $\Phi$ 'cf. large' or $\Phi$ 'large' is impossible. In fact, the specimens shown (from the Rio Tapajos, Brazil) have the same raphe-sternum structure as in the 'bacillum' group, with grooves running alongside the raphe over its whole length, creating a small elliptical 'central nodule' enclosing the central raphe endings. REAVIE \& SMOL (1998) illustrate a valve they identify as "Navicula laevissima", which seems to agree morphologically with $\Phi$ 'cf. large'; they recorded this diatom as occurring rarely in living and core material from the St Lawrence River, Canada. Other strictly linear specimens from $\mathrm{N}$ America that resemble $\Phi$ 'cf. large', but are c. $1 \mu \mathrm{m}$ narrower at any given length than in British material, have been illustrated from Massachusetts by Schoeman \& Archibald (1976-1980, figs 24-27).

\section{Sellaphora [pupula K-LB] Ф 'dumbbell' (Fig.} 43)

Valves almost linear, with broadly capitate or subcapitate poles, $32.5-46 \times 8.75-9.25 \mu \mathrm{m}$. Striae radiate and curved, becoming parallel near the poles, with some intercalated short striae at the centre, 19.2-20.8-21.7 in $10 \mu \mathrm{m}$; areolae invisible in LM. Axial area narrow. Central area strongly expanded (to c. $60-70 \%$ of the valve width), somewhat irregularly bow-tie-shaped. Shallow grooves apparently present externally alongside the raphe-sternum. Raphe sinuous. Polar bars present, radiate.

\section{Sellaphora blackfordensis (Fig. 44)}

Valves linear-elliptical, with broad, subcapitate poles (becoming rostrate in the smallest specimens), 19-48 (57) × 8.0-9.75 $\mu \mathrm{m}$. Striae radiate, curved, with some intercalated short striae at the centre, 17.8-19.6-20.7 in $10 \mu \mathrm{m}$; areolae invisible in LM. Axial area narrow. Central area expanded (to c. $55-65 \%$ of the valve width), somewhat irregular, mostly bow-tie-shaped or transversely rectangular. Raphe-sternum often well-defined, through development of slight grooves alongside it externally. Raphe sinuous. Polar bars present, radiate or more rarely parallel. DNA BARCODE (COX1): GenBank EF164948.

Remarks: Figured valves from Santa Fiora, Italy (SCHOEMAN \& ArChibald 1976-1980, figs 13, 14), and Falaise, France (MANN 2001, figs 17, 18) are probably of $S$. blackfordensis. Two further valves were illustrated by Lange-Bertalot \& Metzeltin (1996, pl. 82, figs 4, 5, referred to "Morphotyp Nr. 5 Mittersee") and said to be synonymous with Blackford Pond deme 'rectangular' sensu MANN (1989b), which was described formally as $S$. blackfordensis by MANN et al. (2004). The valves shown by LANGe-Bertalot \& Metzeltin have the right stria density (c. 19 in $10 \mu \mathrm{m})$ for $S$. blackfordensis and their shape and the strikingly sinuous raphe system are also appropriate for this species. However, the two valves measure $45.7 \times 10.5$ and $43.4 \times$ 10.3 and we have not found valves as wide as this in $S$. blackfordensis. Lange-Bertalot \& Metzeltin (1996, p. 282) suggest that "Dieser Morphotyp steht auch $S$. parapupula nahe (?identisch)" but it is inconceivable to us that the two valves of "Morphotyp 5" from the Mittersee, Austria, belong to the same phenodeme as the specimens of "S. parapupula" illustrated alongside them by Lange-Bertalot \& Metzeltin (1996, pl. 82, figs 1-3; see also remarks under [pupula] $\Phi$ 'gross'). Metzeltin et al. (2005, pp. 209-211) described a new species $S$. rhombicarea, from the Río Cebollatii, Uruguay, which resembles $S$. blackfordensis but is somewhat larger and generally has a rhombic central area, rather than the transversely rectangular or bow-tieshaped area usually found in S. blackfordensis. There is some confusion about which of Metzeltin et al.'s figures show S. rhombicarea: the text states that pl. 66, 


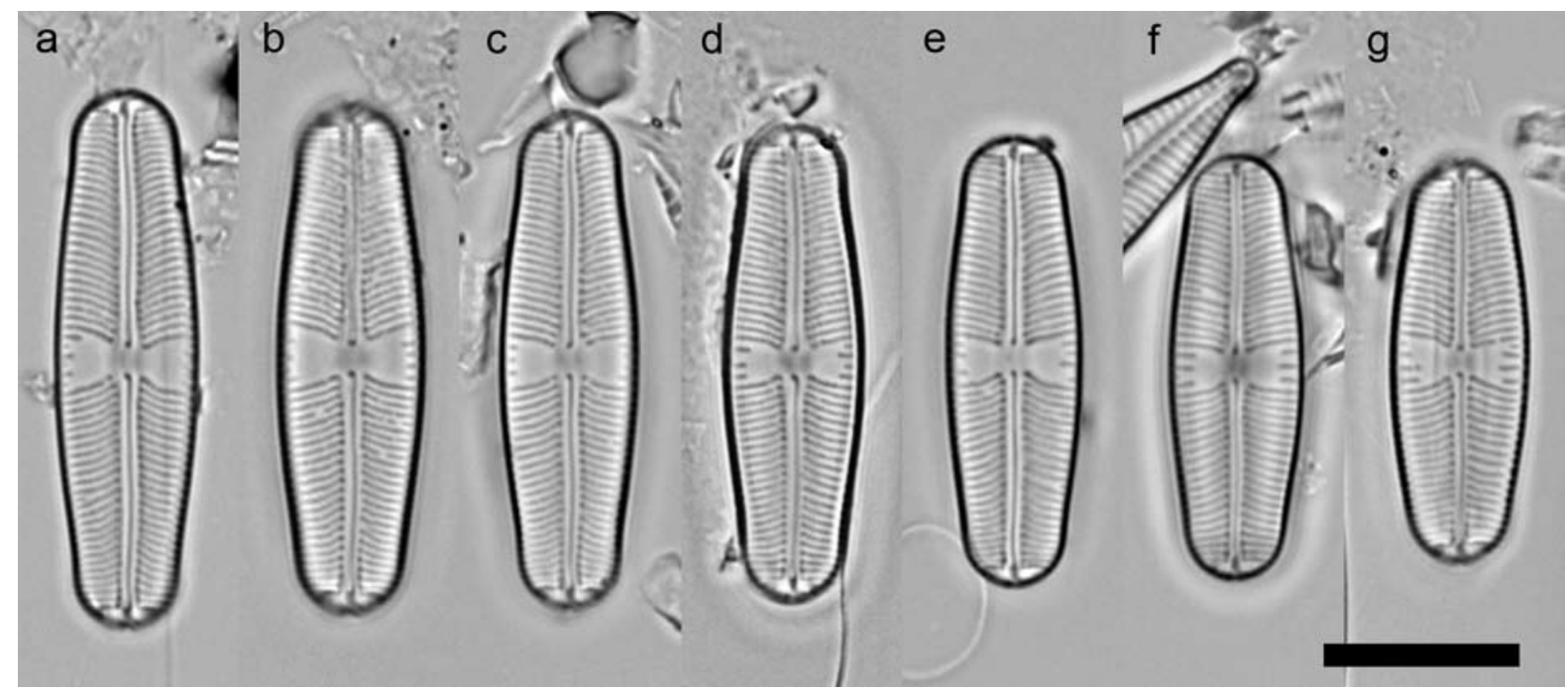

Fig. 38. Sellaphora [pupula K-LB] $\Phi$ ‘europa’: Priest Pot; (a, e) slide E3683/2; (b-d, f, g) slide E3683/1. Scale bar $=10 \mu \mathrm{m}$.

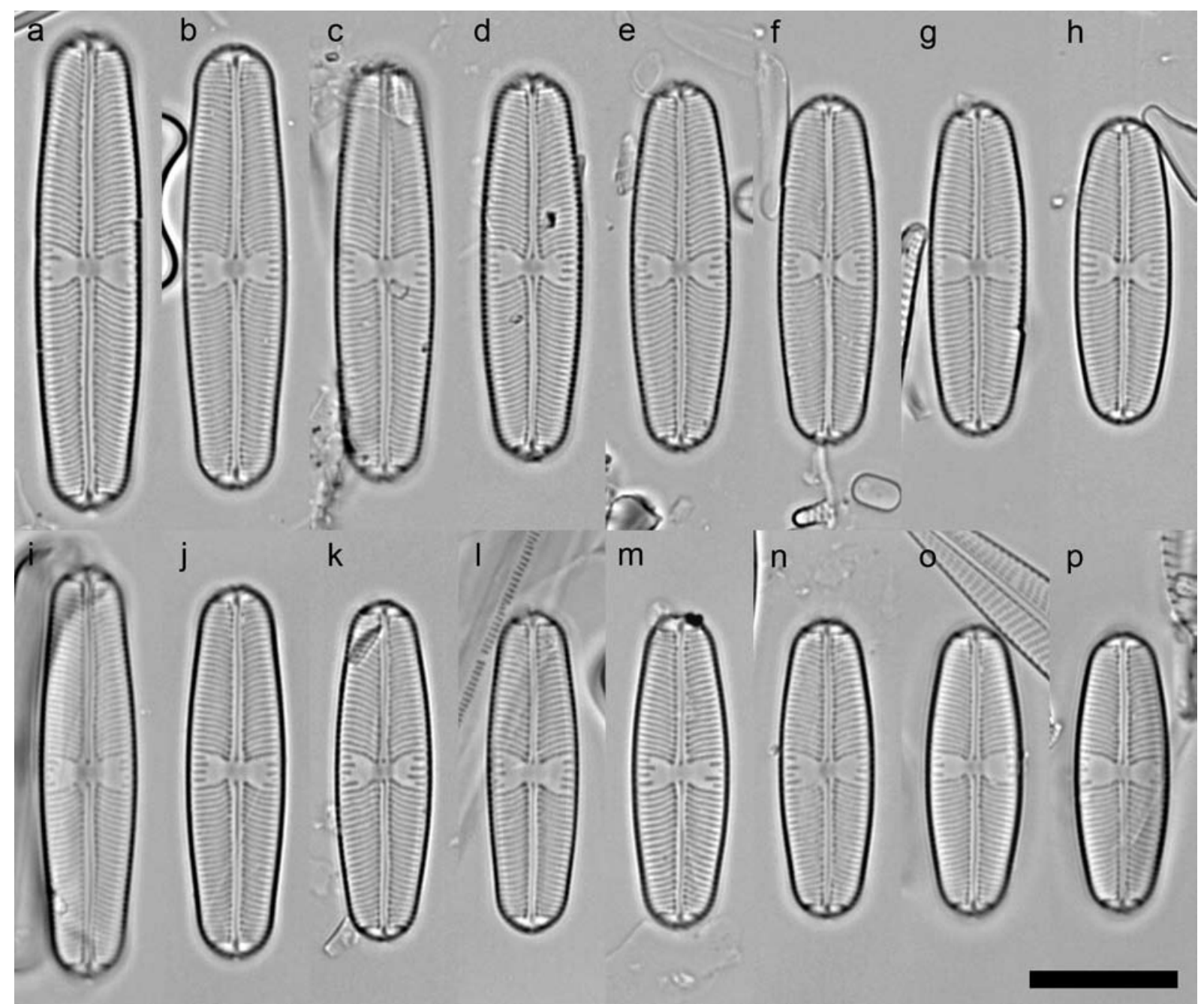

Fig. 39. Sellaphora [pupula K-LB] $\Phi$ ‘small blunt-capitate': (a-h) Loch Maree, slide 2749.1; (i-p) Loch Achray, slide E3585/1. Scale bar $=10 \mu \mathrm{m}$. 


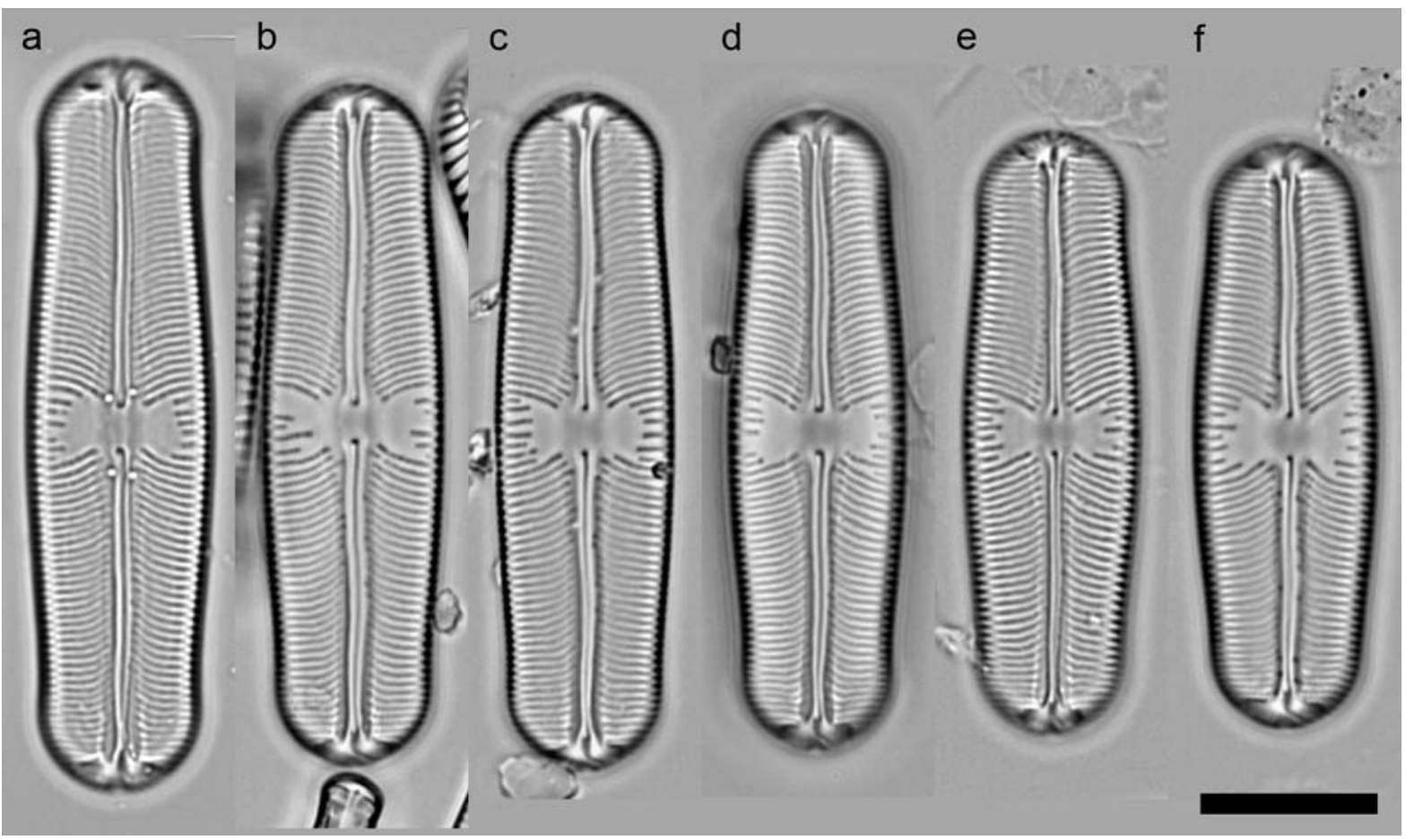

Fig. 40. Sellaphora [pupula K-LB] $\Phi$ 'gross': Threipmuir Reservoir; (a, c) slide 'Threipmuir Marsh Basin usual 11.6.86 B (thin)'; (b, d-f) slide E2588/3. Scale bar $=10 \mu \mathrm{m}$.

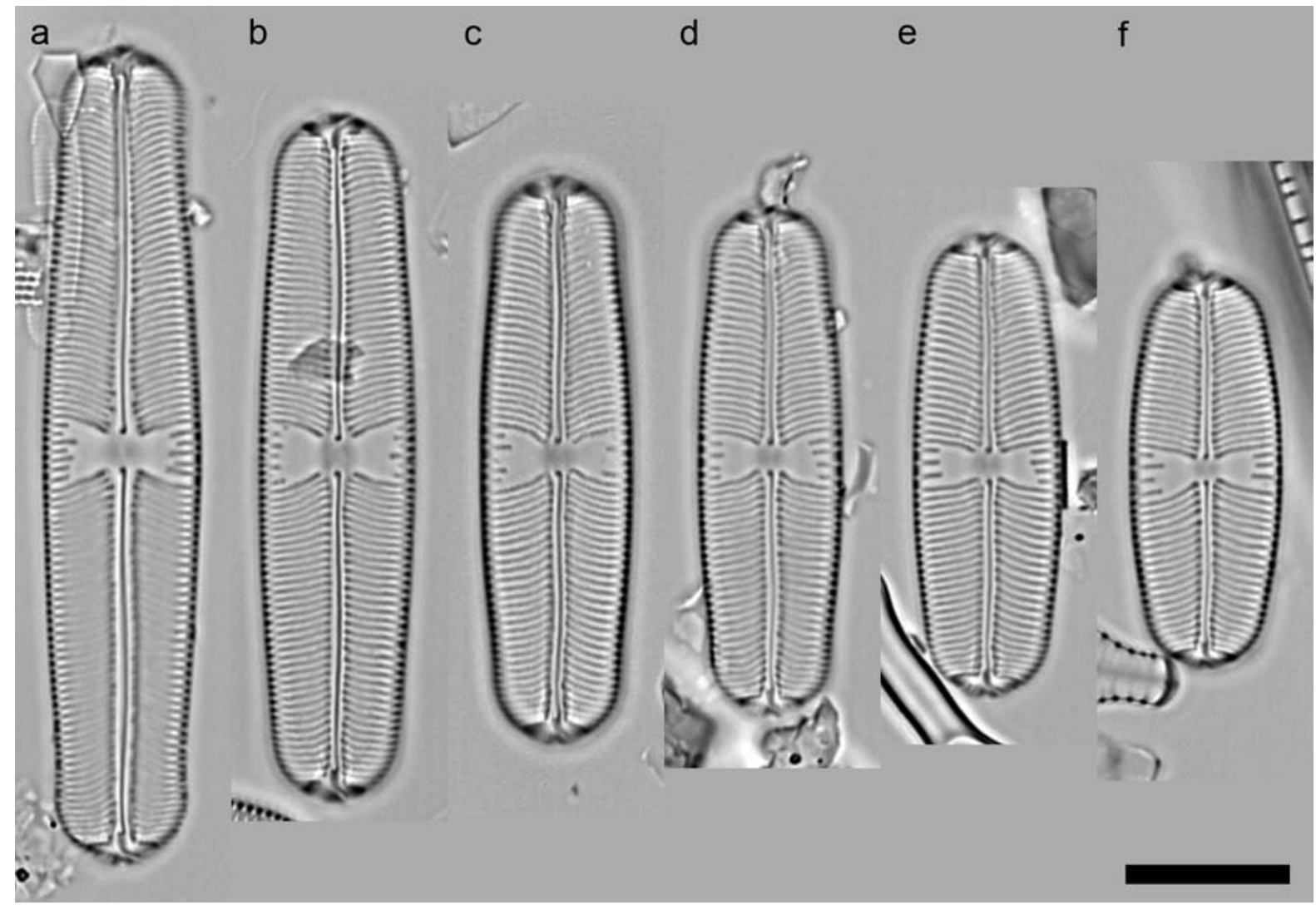

Fig. 41. Sellaphora [pupula K-LB] $\Phi$ 'large': Threipmuir Reservoir; (a, b, d, e) 'Threipmuir NE Basin sandy ... 11.6.86 A'; (c, f) 'Threipmuir Middle Basin NW end/coffer dam 11.6.86 C'. Scale bar $=10 \mu \mathrm{m}$. 


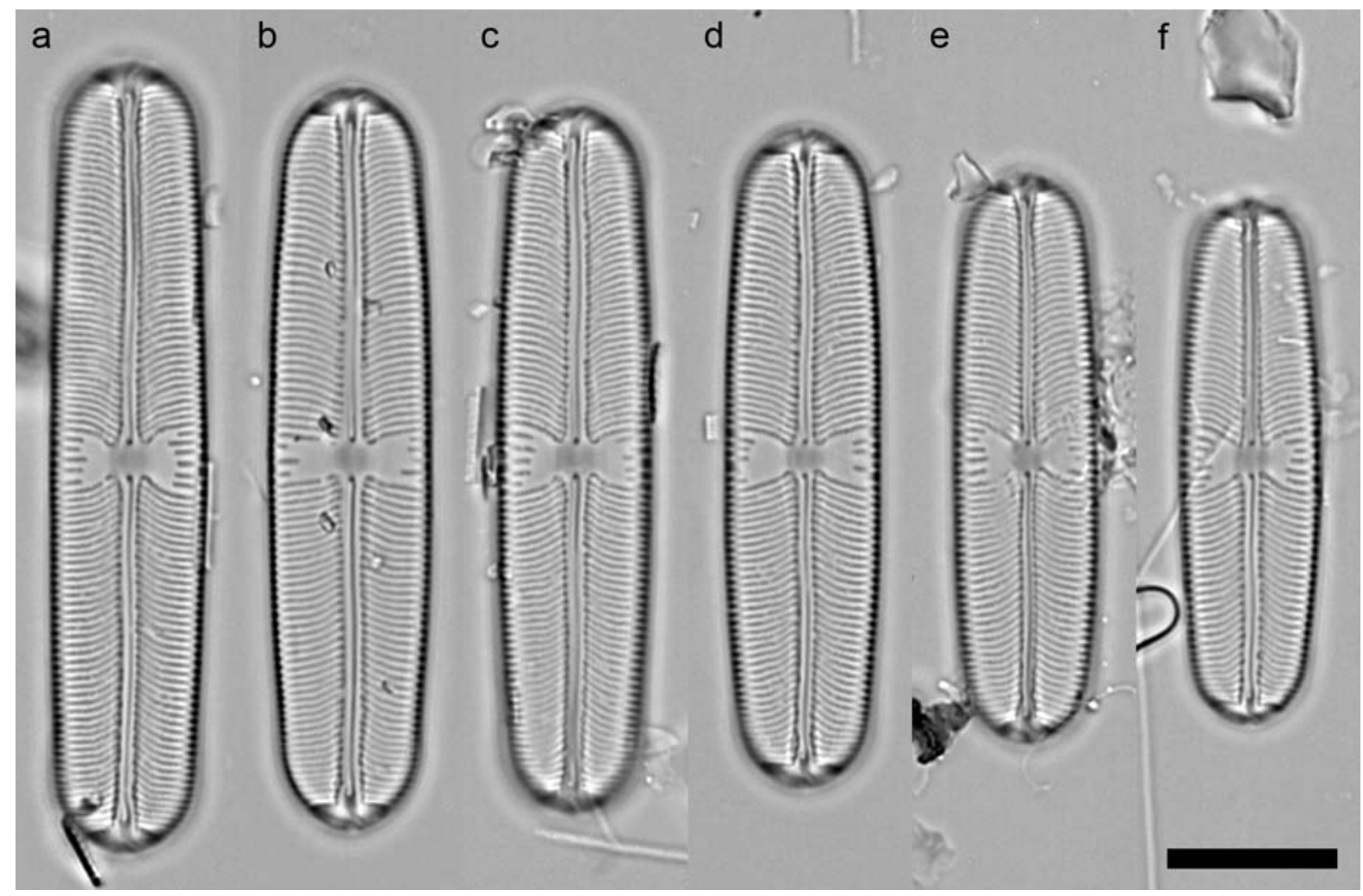

Fig. 42. Sellaphora [pupula K-LB] $\Phi$ ‘cf. large’: Loch Maree; (a, c, d) slide E2763.1; (b, e, f) slide E2749.1. Scale bar = 10 $\mu \mathrm{m}$.

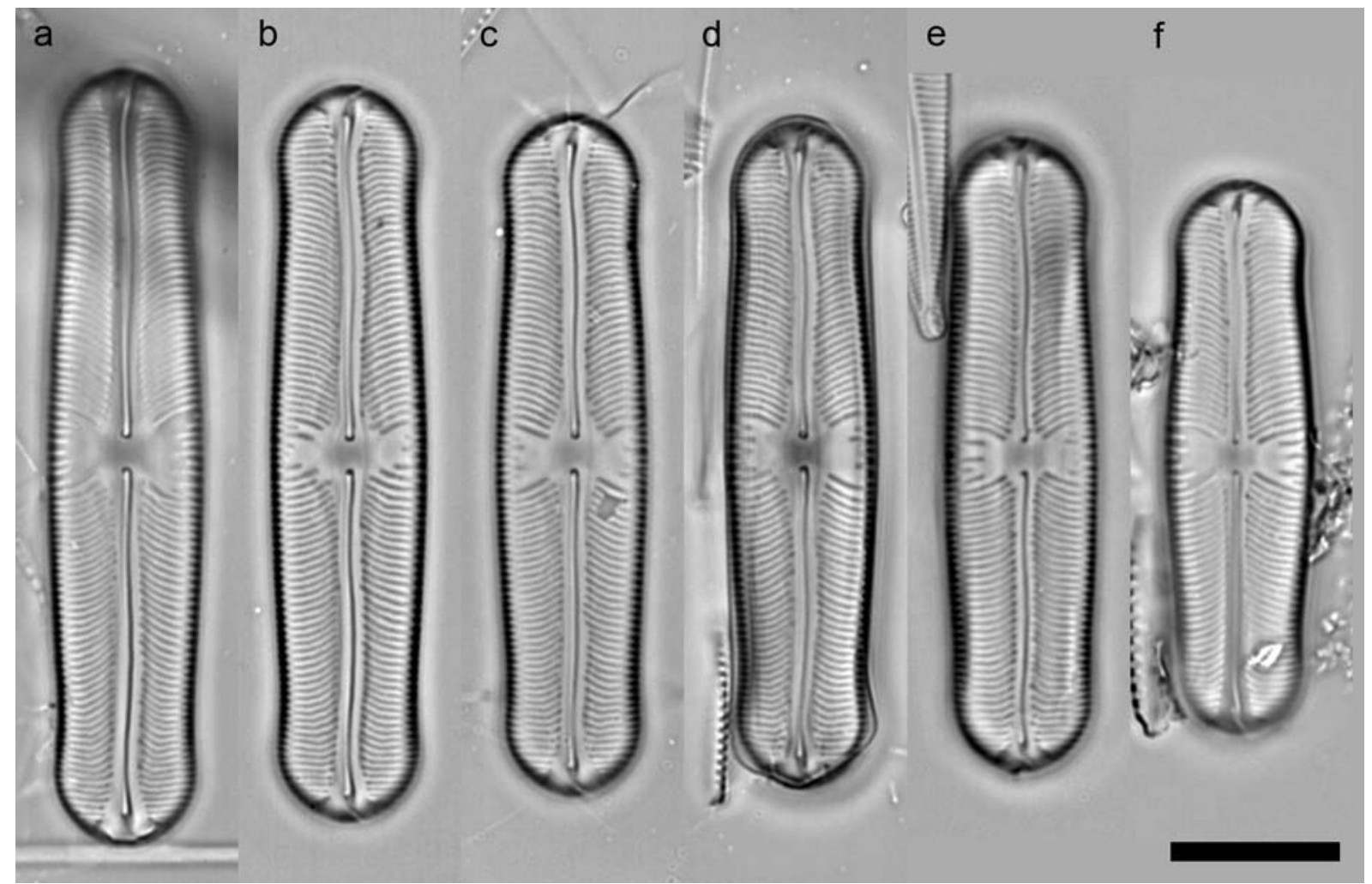

Fig. 43. Sellaphora [pupula K-LB] $\Phi$ 'dumbbell': (a, d) Heart Moss, slide E424/2; (b, c) Heart Moss, slide E423/1; (e) Loch of Craiglush, slide E323/2; (f) Loch of Butterstone, slide E327/3. Scale bar $=10 \mu \mathrm{m}$. 

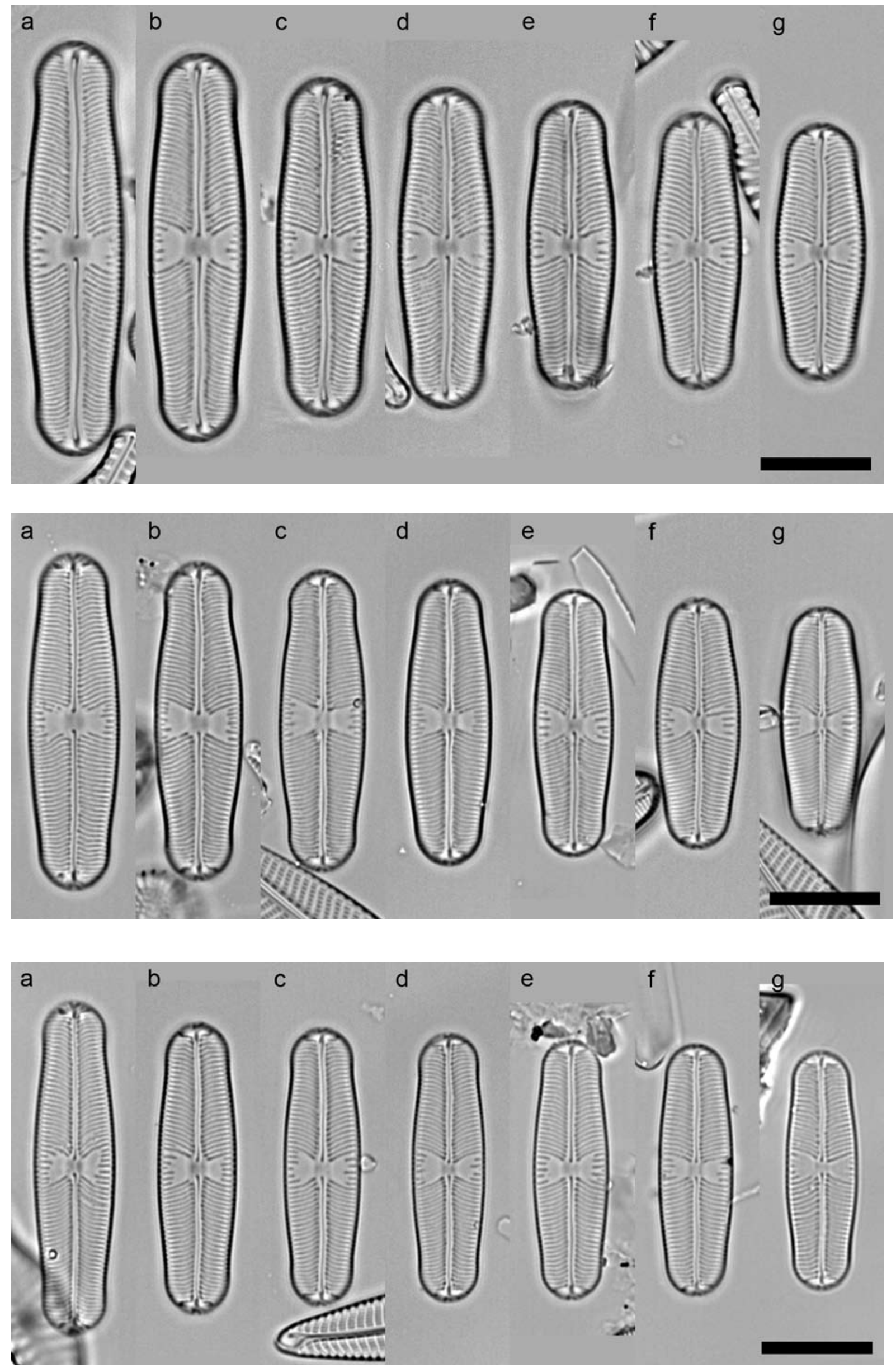
figs 1-17 all show $S$. rhombicarea, whereas the figure legends restrict $S$. rhombicarea to figs 4-17. However, since figs $1-3$ show diatoms that clearly differ from the remainder in raphe structure and valve outline (even though figs 2 and 3 do not, as claimed, show $S$. laevissima, since the diatoms shown possess polar bars; the same error occurs in pl. 65, figs 20-32, and in MetzeLTIN \& GARCÍA-RODRÍGUEZ 2003), it must be the legends that are correct.

\section{Sellaphora [pupula K-LB] Ф 'pseudocapitate' (Fig. 45)}

Valves linear-elliptical, with broad, subcapitate poles (becoming rostrate in the smallest specimens), $20-33 \times 7.25-8.5 \mu \mathrm{m}$. Striae radiate, straight to slightly curved, with some intercalated short striae at the centre, 20.7-22.0-23.9 in $10 \mu \mathrm{m}$; areolae invisible in LM. Axial area very narrow. Central area expanded (to $50-70 \%$ of the valve width), somewhat irregular, bow-tie-shaped or transversely rectangular. A groove is apparently present externally alongside the raphe-sternum. Raphe slightly sinuous. Polar bars present, parallel to radiate.

REMARKS: It is very difficult to separate this morphologically from $\Phi$ cf. capitate, but molecular data (Evans et al. 2007, 2008) indicate that they are separate. They may be distinguishable by the greater width of the valve and poles in $\Phi$ 'pseudocapitate' but the ranges of variation seem to overlap.

\section{Sellaphora [pupula K-LB] $\Phi$ 'cf. capitate' (Fig. 46)}

Valves linear-elliptical, with broad, subcapitate poles (becoming rostrate in the smallest specimens), $18.5-41.5 \times 6.5-7.75 \mu \mathrm{m}$. Striae radiate, curved to straight, with some intercalated short striae at the centre, $21.5-22.7-23.5$ in $10 \mu \mathrm{m}$; areolae invisible in LM. Axial area very narrow. Central area expanded (to c. $50-70 \%$ of the valve width), somewhat irregular, mostly bowtie-shaped or transversely rectangular, but occasionally transversely elliptical. Shallow grooves apparently present externally alongside the raphe-sternum. Raphe slightly sinuous. Polar bars present, parallel to radiate. DNA BARCODE (COX1):
GenBank EF164937.

\section{Sellaphora capitata (Fig. 47)}

Valves linear-elliptical, with broad, subcapitate poles (capitate in the largest specimens), 19-35 (44) $\times 7-8.25(9.3) \mu \mathrm{m}$. Striae radiate, curved and usually angled near the poles, with some intercalated short striae at the centre, (16) 18.219.3-20.5 (22) in $10 \mu \mathrm{m}$; areolae invisible in LM. Axial area narrow. Central area expanded (to c. $55-70 \%$ of the valve width), somewhat irregular, mostly bow-tie-shaped or transversely rectangular. No obvious groove alongside the raphe-sternum. Raphe slightly sinuous. Polar bars present, usually parallel. DNA BARCODE (COX1): GenBank EF164947.

Remarks: Metzeltin \& Lange-Bertalot (2002, pl. 31, figs 19-22) compare four specimens from Ivato, Madagascar, to "phenodeme 3 sensu D.G. Mann 1984", which became $S$. blackfordensis. However, a better match, at least for the specimen shown in their fig. 20, would be $S$. capitata, with which it agrees in dimensions, shape, stria pattern and stria density (compare with our Fig. $47 \mathrm{~d}$, e).

\section{Sellaphora [pupula K-LB] Ф 'caput' (Fig. 48)}

Valves linear-elliptical, with broad, capitate poles (becoming subcapitate or rostrate in the smallest specimens), $18-38 \times 6.25-7.25 \mu \mathrm{m}$. Striae radiate, slightly curved, with some intercalated short striae at the centre, 22.6-24.7-26.0 in $10 \mu \mathrm{m}$; areolae invisible in LM. Axial area very narrow. Central area strongly expanded (to $60-70 \%$ of the valve width), somewhat irregular, transversely rectangular to \pm bow-tie-shaped. Perhaps with shallow grooves externally alongside the raphe-sternum. Raphe slightly sinuous. Polar bars present, parallel to slightly radiate.

\section{Sellaphora [pupula K-LB] $\Phi$ 'small capitate' (Fig. 49)}

Valves linear-elliptical, with broad, capitate poles (becoming subcapitate or rostrate in the smallest specimens), $18.5-27 \times 5.5-6.5 \mu \mathrm{m}$. Striae radiate, slightly curved, with some intercalated short

Fig. 44. Sellaphora blackfordensis: Blackford Pond; (a-f) slide E3667/2; (g) slide 'Blackford Pond 18.12.86 thin 1'. In (a), some striae appear punctate because of missing areolae. Scale bar $=10 \mu \mathrm{m}$.

Fig. 45. Sellaphora [pupula K-LB] $\Phi$ 'pseudocapitate': Threipmuir Reservoir; (a, b, e) slide 'Threipmuir Marsh Basin usual 11.6.86 B (thin)'; (c, d, f, g) slide 'Threipmuir Middle Basin NW end/coffer dam 11.6.86 C'. Scale bar $=10 \mu \mathrm{m}$.

Fig. 46. Sellaphora [pupula K-LB] $\Phi$ 'cf. capitate': Threipmuir Reservoir; (a, b, g) slide 'Threipmuir Marsh Basin usual 11.6.86 B (thin)'; (c, d, f) 'Threipmuir Middle Basin NW end/coffer dam 11.6.86 C'; (e) 'Threipmuir NE Basin sandy ... 11.6.86 A'. Scale bar $=10 \mu \mathrm{m}$. 


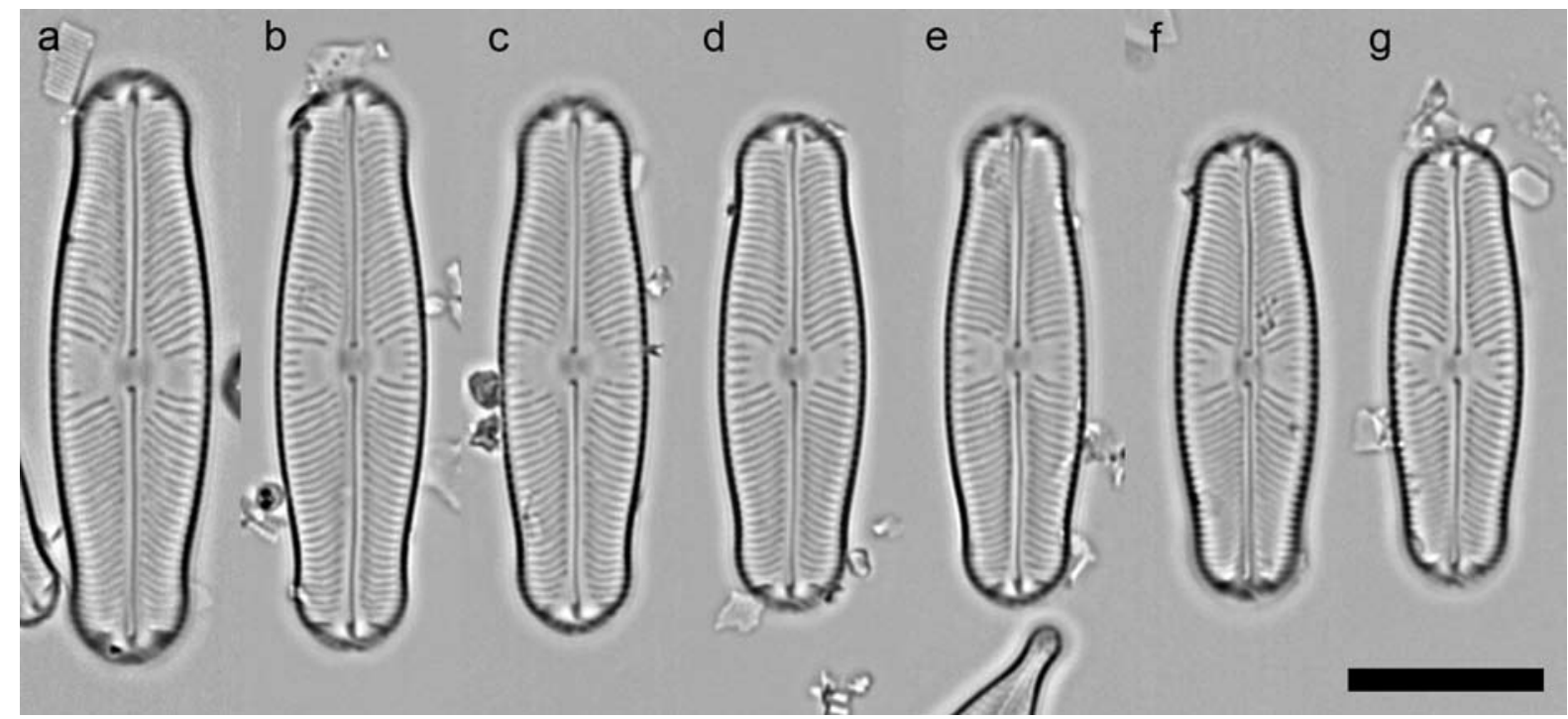

Fig. 47. Sellaphora capitata. (a) Blackford Pond, slide E3667/2. (b-g) Dunsapie Loch, slide E3572. Scale bar $=10 \mu \mathrm{m}$.

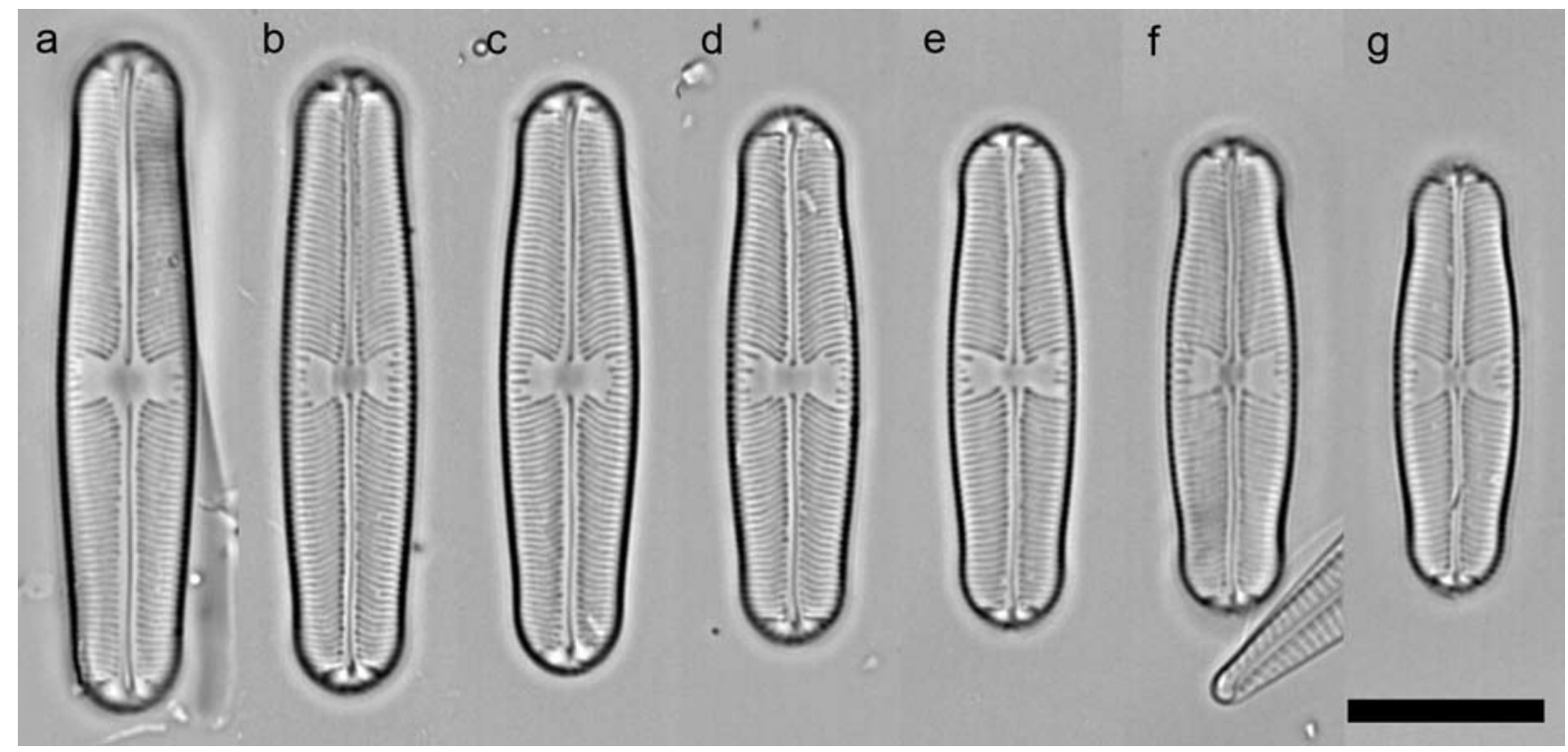

Fig. 48. Sellaphora [pupula K-LB] $\Phi$ ‘caput'. (a-d) Loch Tulla, slide E297. (e-g) Loch Achray, slide E3585/1. Scale bar = 10 $\mu \mathrm{m}$.

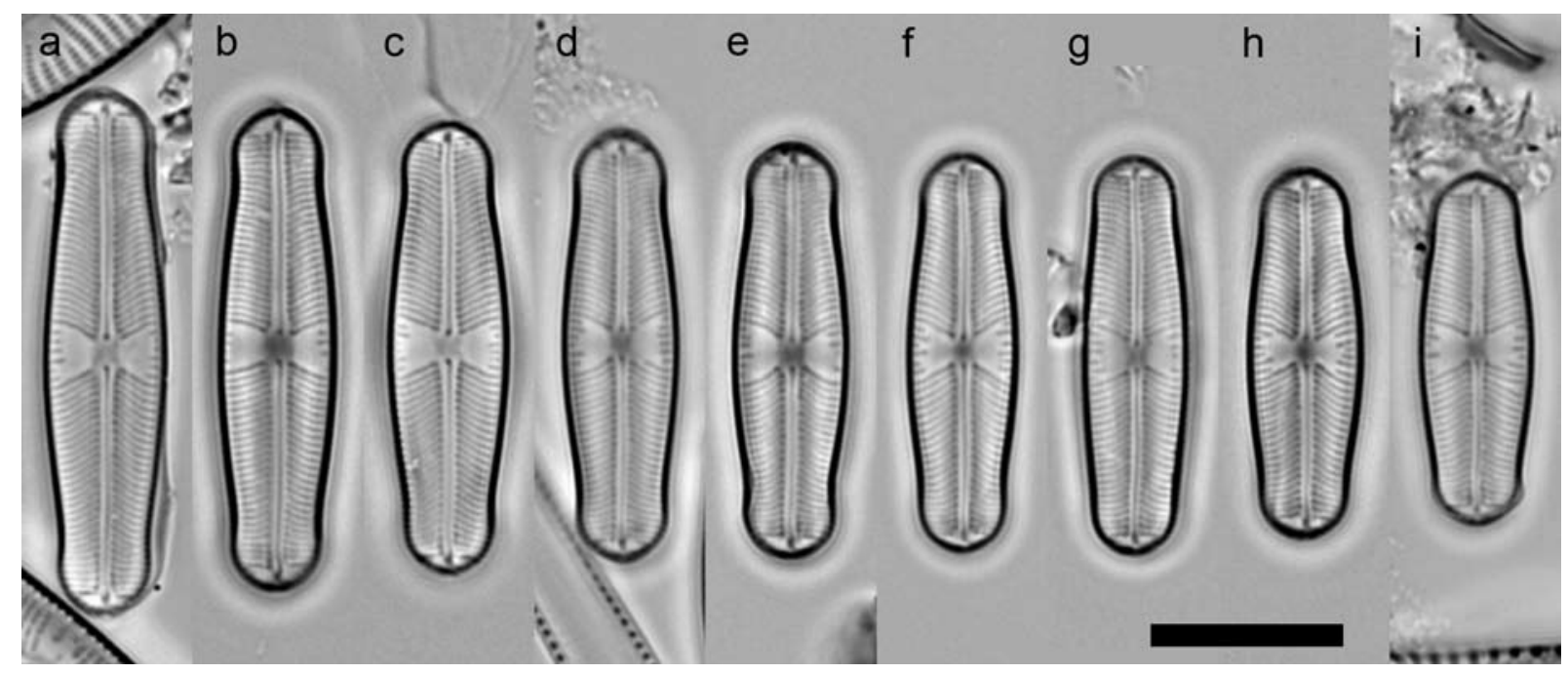


striae at the centre, 22.8-25.0-27.3 in $10 \mu \mathrm{m}$; areolae invisible in LM. Axial area narrow. Central area strongly expanded (to $60-85 \%$ of the valve width), somewhat irregular, \pm bow-tie-shaped. Perhaps with shallow grooves externally alongside the raphe-sternum. Raphe very slightly sinuous. Polar bars present, parallel to radiate. DNA BARCODE (COX1): GenBank EF164936.

REMARKS: Many small capitate and subcapitate examples of the 'pupula' group have been illustrated in the literature but few can be reconciled with any confidence with any of our phenodemes. However, the lectotype of Navicula pupula var. subcapitata Hust. selected by SimONSEN (1987, p. 21 and pl. 5, fig. 8) agrees well with $\Phi$ 'small capitate' (better indeed than with HusteDT's original illustrations of var. subcapitata! see HUSTEDT 1911, pl. 3, figs 38, 41).

\section{LAEVISSIMA GROUP}

\section{Sellaphora [laevissima K-LB] Ф 'heart' (Fig.} 50)

Valves linear, with margins very slightly bowed outwards towards the centre and very slightly acute but rounded poles that are subcapitate or somewhat abruptly set off from the lateral margins, 33-48.5 × 9.25-10.5 $\mu \mathrm{m}$. Striae curved and slightly radiate centrally, becoming more strongly radiate and often angled near the poles, sometimes with a few intercalated short striae at the centre, 15.5-16.3-17.2 in $10 \mu \mathrm{m}$; areolae visible in LM. Axial area narrow, occupying c. $15 \%$ of the valve width. Central area expanded (to $50-65 \%$ of the valve width), often ill-defined, transversely elliptical to transversely rectangular. Raphe-sternum usually well-defined because of adjoining grooves on either side that are continuous across the centre, expanded into a narrowly elliptical 'central nodule' surrounding the central raphe endings. Raphe sinuous. Polar bars absent.

Remarks: Probably the same as the single valve from the Mittersee, Austria, illustrated by LANGE-Bertalot \& Metzeltin (1996, pl. 81, fig. 15) as "Sellaphora laevissima (Kütz.) Mann”. See also under [laevissima] $\Phi$ 'normal'.

\section{Sellaphora [laevissima K-LB] Ф 'normal' (Fig. 51)}

Valves linear, with margins very slightly bowed outwards towards the centre and rounded poles that are slightly subcapitate or broadly rostrate, $23-49 \times 7.0-8.5 \mu \mathrm{m}$. Striae straight or curved and slightly radiate, occasionally angled near the poles, 17.3-19.4-19.8 in $10 \mu \mathrm{m}$; areolae scarcely or not visible in LM. Axial area narrow, occupying c. $15 \%$ of the valve width. Central area expanded (to $50-60 \%$, sometimes $80 \%$ of the valve width), often ill-defined, transversely elliptical to transversely rectangular. Raphe-sternum bordered by a shallow groove externally. Raphe sinuous. Polar bars absent.

Remarks: LANGe-Bertalot et al. (2003) have designated Schoeman \& Archibald's (1976-1980) fig. 10 as a second-stage lectotype for $S$. laevissima, because the original material of the species, from Santa Fiora, Italy, is demonstrably heterogeneous. Of the [laevissima] demes documented here, $\Phi$ 'normal' seems the closest to the lectotype illustration, which is c. $8.5 \mu \mathrm{m}$ wide with c. 18.5 striae in $10 \mu \mathrm{m}$. However, the type material also contains wider specimens $(9.5-10.5 \mu \mathrm{m})$ with 15-17 striae in $10 \mu \mathrm{m}$ that are more similar to $\Phi$ 'heart' (LANGE-BerTALOT et al. 2003, pl. 23, figs 1-3) and strictly linear specimens (c. $8.5 \mu \mathrm{m}$ wide) with simply rounded poles and c. 14 striae in $10 \mu \mathrm{m}$ that can be assigned to $\Phi$ 'very coarse' (SCHOEMAN \& ARCHIBALD 1976-1980, fig. 5).

\section{Sellaphora [laevissima K-LB] $\Phi$ 'small' (Fig. 52)}

Valves linear, with margins very slightly bowed outwards towards the centre and rounded poles that are slightly subcapitate or broadly rostrate, $21.5-28 \times 6.75-7.25 \mu \mathrm{m}$. Striae straight or curved and slightly radiate, often angled near the poles, 18.3-19.4-20.9 in $10 \mu \mathrm{m}$; areolae invisible in LM. Axial area very narrow, occupying c. $10 \%$ of the valve width. Central area expanded (to c. $50 \%$ of the valve width), ill-defined, \pm transversely rectangular. Raphe-sternum well-defined because of adjoining grooves on either side that are continuous across the centre, expanded into a narrowly elliptical 'central nodule' surrounding the central raphe endings. Raphe slightly sinuous. Polar bars absent.

\section{Sellaphora [laevissima K-LB] $\Phi$ 'very coarse'} (Fig. 53)

Valves strictly linear, with rounded poles, $22.5-43$ $\times 8.0-9.25 \mu \mathrm{m}$. Striae straight or slightly curved, parallel to slightly radiate, becoming more radi-

Fig. 49. Sellaphora [pupula K-LB] $\Phi$ ‘small capitate': Dunsapie Loch; (a-f, h, i) slide E4109/2; (g) slide E3572. Scale bar = $10 \mu \mathrm{m}$. 


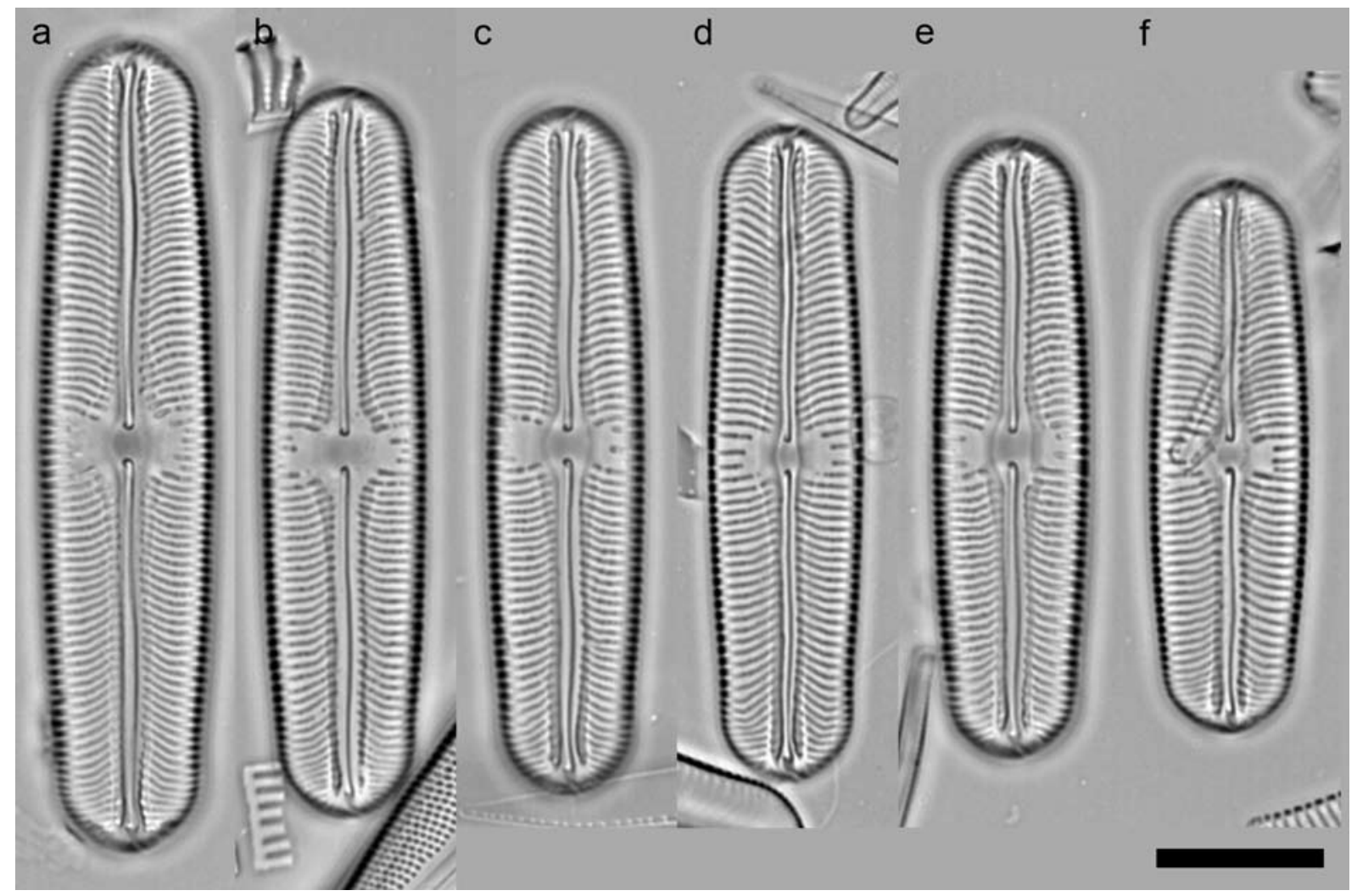

Fig. 50. Sellaphora [laevissima K-LB] $\Phi$ 'heart’: Heart Moss; (a-f) slide E424/2. Scale bar $=10 \mu \mathrm{m}$.

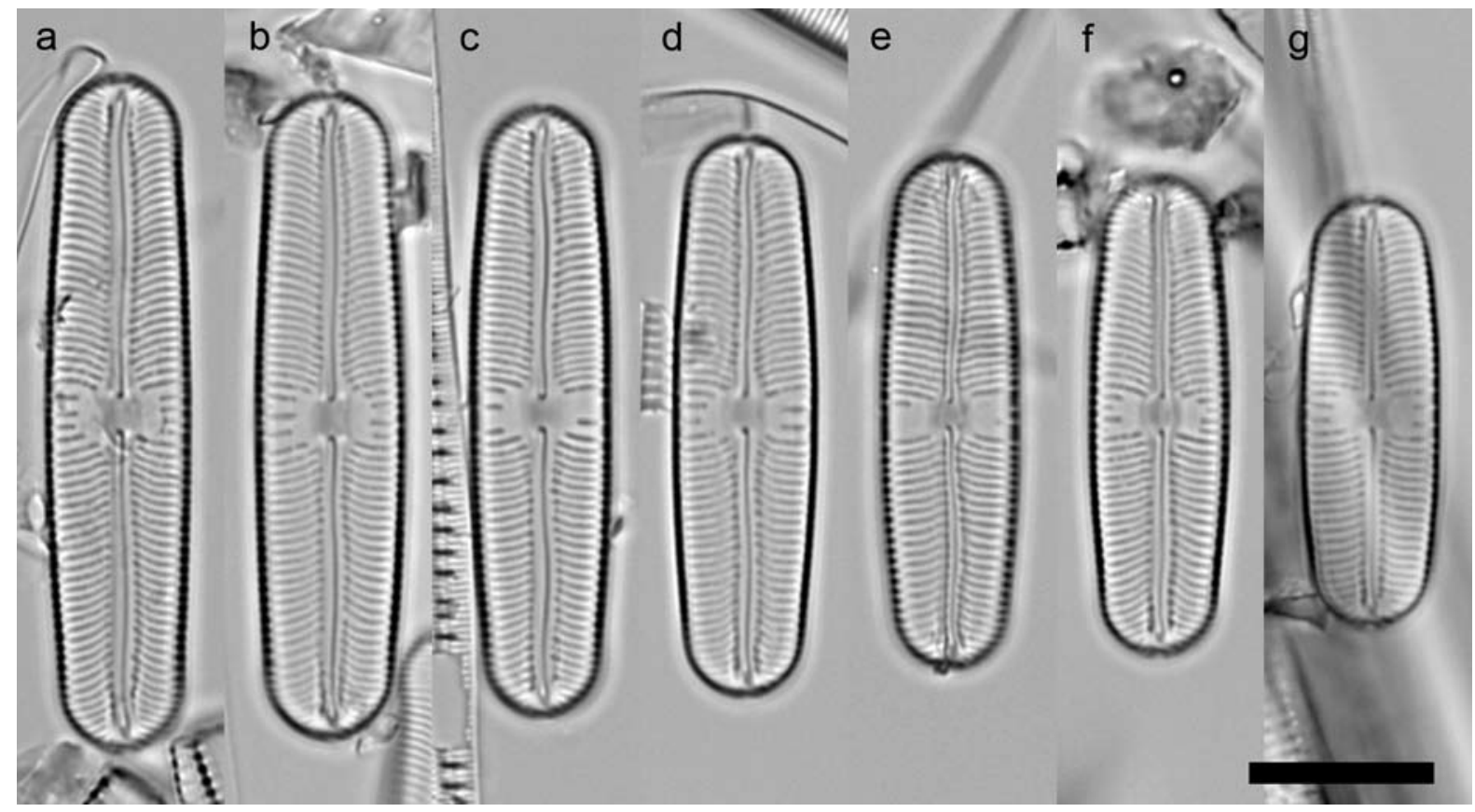

Fig. 51. Sellaphora [laevissima K-LB] $\Phi$ 'normal': Royal Botanic Garden Edinburgh, pond; (a-g) slide E2614/2. Scale bar = $10 \mu \mathrm{m}$. 


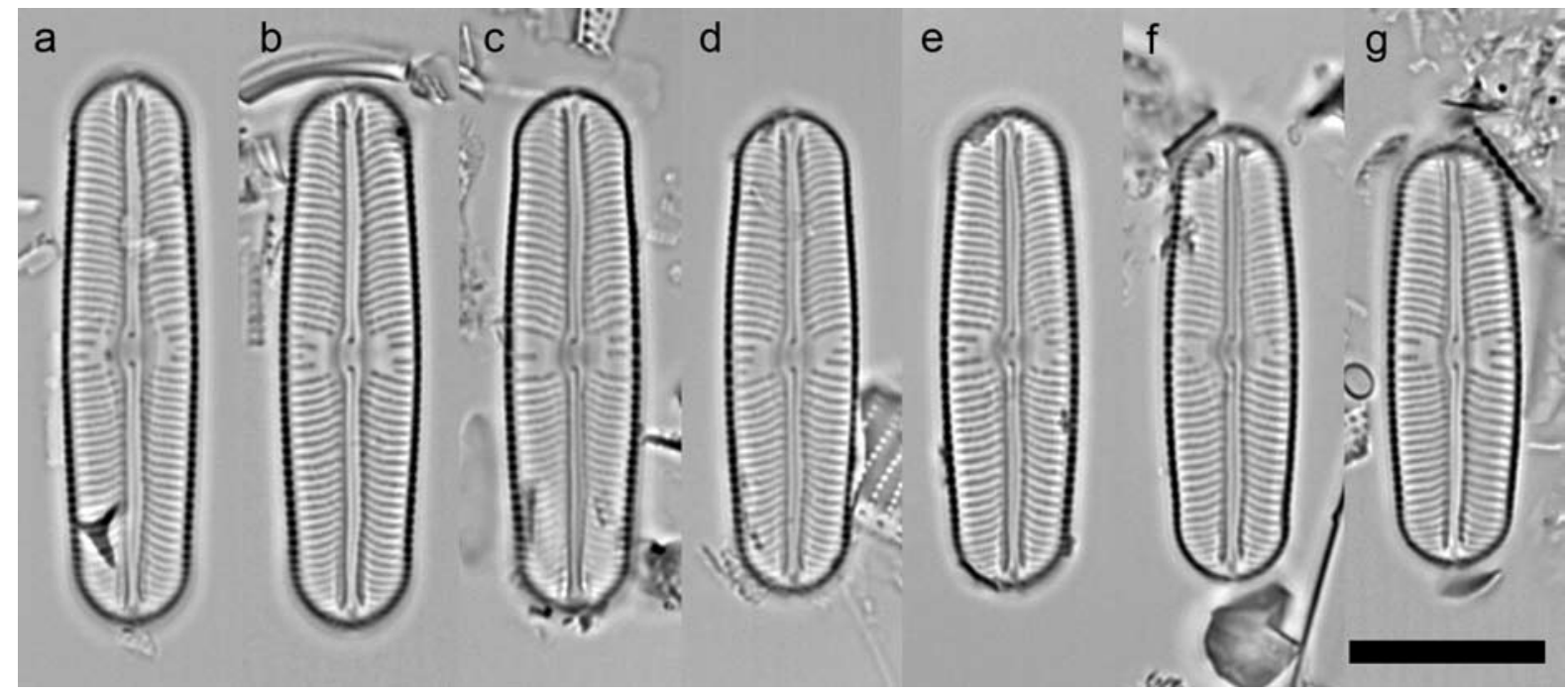

Fig. 52. Sellaphora [laevissima K-LB] $\Phi$ ‘small’: Lake of Menteith; (a-g) slide E3588/2. Scale bar = $10 \mu \mathrm{m}$.

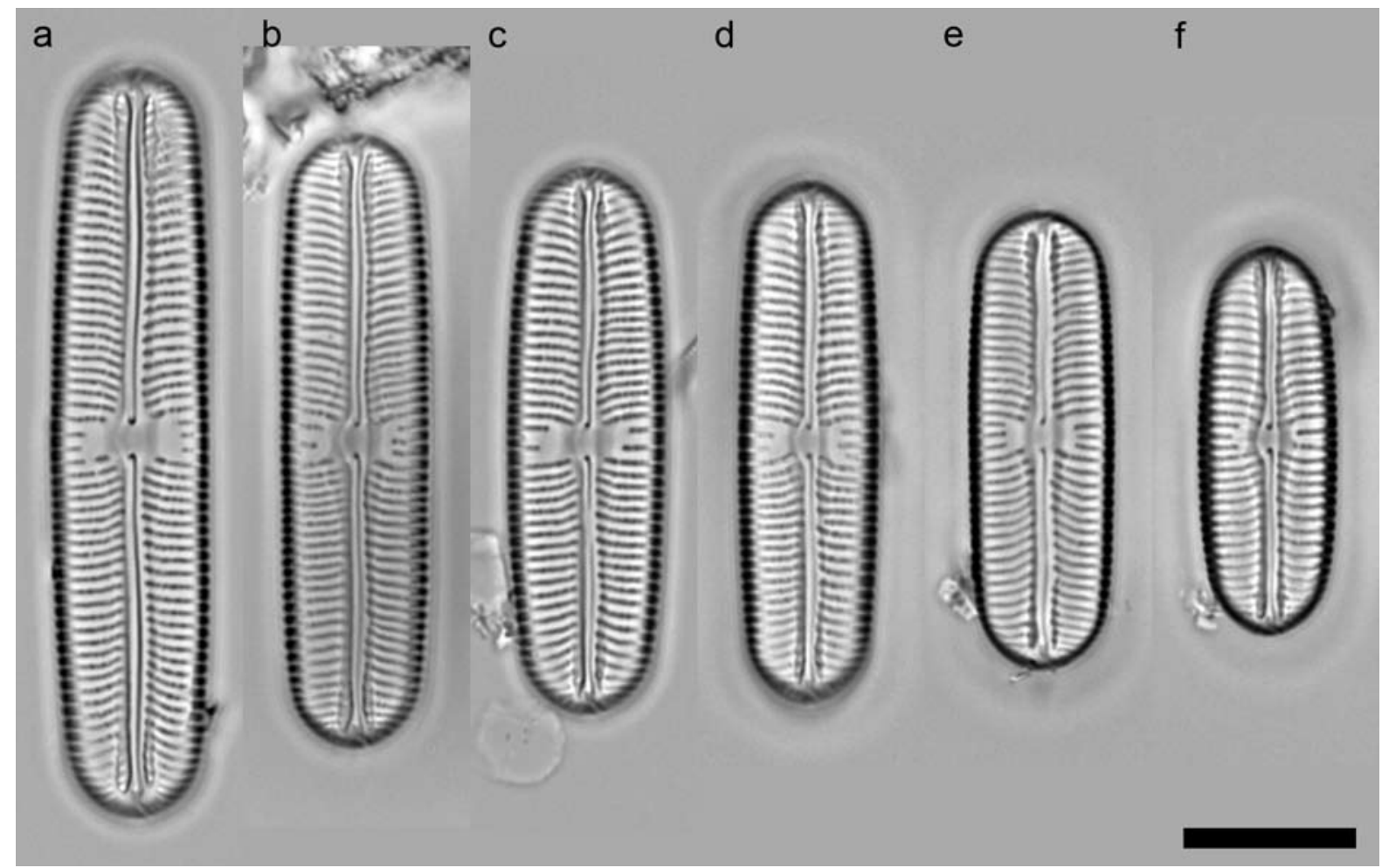

Fig. 53. Sellaphora [laevissima K-LB] $\Phi$ 'very coarse': (a, c) Loch of Butterstone, slide E3673/1; (b) Loch of Clunie, slide E3671/2; (d-f) Loch of Clunie, slide E328/3. Scale bar $=10 \mu \mathrm{m}$.

ate and occasionally angled near the poles, $13.8-$ $14.9-16.3$ in $10 \mu \mathrm{m}$; areolae clearly visible in LM. Axial area narrow, occupying c. $15 \%$ of the valve width. Central area expanded (to $45-60 \%$ of the valve width), transversely rectangular to elliptical. Raphe-sternum well-defined because of adjoining grooves on either side that are continuous across the centre, expanded into a narrowly elliptical 'central nodule' surrounding the central raphe endings. Raphe sinuous or slightly sinuous. Polar bars absent.

REMARKs: see comments under $\Phi$ 'normal'.

\section{Sellaphora [laevissima K-LB] $\Phi$ 'perhibita'} (Fig. 54)

Valves strictly linear, with slightly rostrate or rounded poles, $28-52 \times 7.5-9.0 \mu \mathrm{m}$. Striae curved, slightly radiate at the centre, becoming 
more strongly radiate near the poles, sometimes with a few intercalated short striae at the centre, $17.7-18.5-19.2$ in $10 \mu \mathrm{m}$; areolae clearly visible in LM. Axial area occupying $15-20 \%$ of the valve width, widening away from the centre and poles. Central area expanded (to $50-55 \%$ of the valve width), transversely elliptical. Raphe-sternum well-defined because of adjoining grooves on either side that are continuous across the centre, expanded into an elliptical 'central nodule' surrounding the central raphe endings. Raphe sinuous. Polar bars absent.

REMARKS: Our material agrees well with the type material of Navicula perhibita HuST. illustrated by SIMONSEN (1987, pl. 545, figs 1-4), except that external grooves bordering the raphe sternum (clearly visible in our Fig. $54 \mathrm{a}, \mathrm{b}, \mathrm{d}, \mathrm{e}, \mathrm{g}$ ) are not obvious in SiMONSEN's figures (which are, as usual, of excellent quality). HustedT (1950, p. 401) described N. perhibita from mosses on the east shore of the Borgsee, N Germany; our material was obtained by squeezing Acrocladium moss from a mesotrophic mire near Edinburgh. The species was made a variety of $N$. laevissima by LANGE-BERTALOT (in Krammer \& Lange-Bertalot 1985, p. 77) but it has not yet been formally transferred to Sellaphora at any rank. Krammer \& LANGe-Bertalot (1986, p. 189; see also Hustedt 1962, p. 291) note that "Neben jeder Zentralpore erscheinen je zwei kleine 'Punkte', die bei hohem Fokus hell, bei tiefem Fokus dunkel erscheinen" and they can be seen both in SiMONSEN's figures of type specimens and in our illustrations (Fig. 54). It is unclear what causes them.

\section{Sellaphora [cf. laevissima K-LB] $\Phi$ 'barless capitate' (Fig. 55)}

Valves almost linear, with capitate poles, 28-37.5 $\times 7.0-7.5 \mu \mathrm{m}$. Striae curved and radiate throughout, with some intercalated short striae at the centre, 19.9-20.4-21.2 in $10 \mu \mathrm{m}$; areolae invisible in LM. Axial area narrow, occupying c. $15 \%$ of the valve width. Central area expanded (to $55-65 \%$ of the valve width), transversely rectangular to elliptical. No obvious groove alongside the raphe-sternum. Raphe slightly sinuous. Polar bars absent.

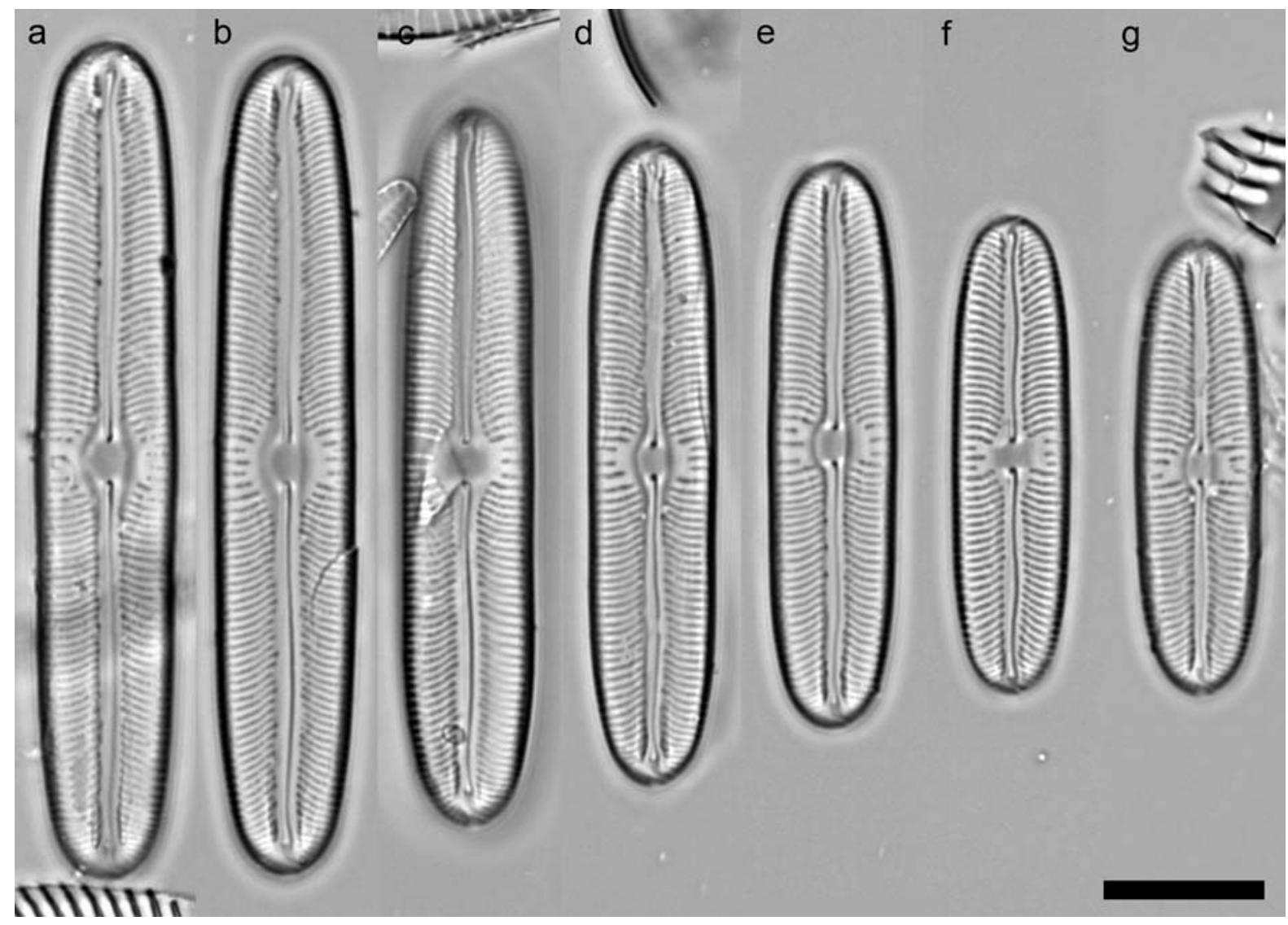

Fig. 54. Sellaphora [laevissima K-LB] $\Phi$ 'perhibita': mire near Threipmuir Reservoir; (a-g) slide 'NE Threipmuir Acrocladium ... sample 7, 2.4.81, slide 2'. Scale bar $=10 \mu \mathrm{m}$. 
REMARKS: We suspect that this diatom and the next have often been seen previously but recorded as 'Navicula. pupula var. capitata', because the absence of polar bars was overlooked.

\section{Sellaphora [cf. laevissima K-LB] $\Phi$ 'mini-bar- less capitate' (Fig. 56)}

Valves almost linear, with capitate poles, $24-28 \times$ 5.75-6.75 $\mu \mathrm{m}$. Striae curved and radiate through- out, with some intercalated short striae at the centre, 20.2-22.5-26.0 in $10 \mu \mathrm{m}$; areolae invisible in LM. Axial area narrow, occupying c. $15 \%$ of the valve width. Central area expanded (to $55-65 \%$ of the valve width), transversely rectangular to elliptical. No obvious groove alongside the raphe-sternum. Raphe slightly sinuous. Polar bars absent.

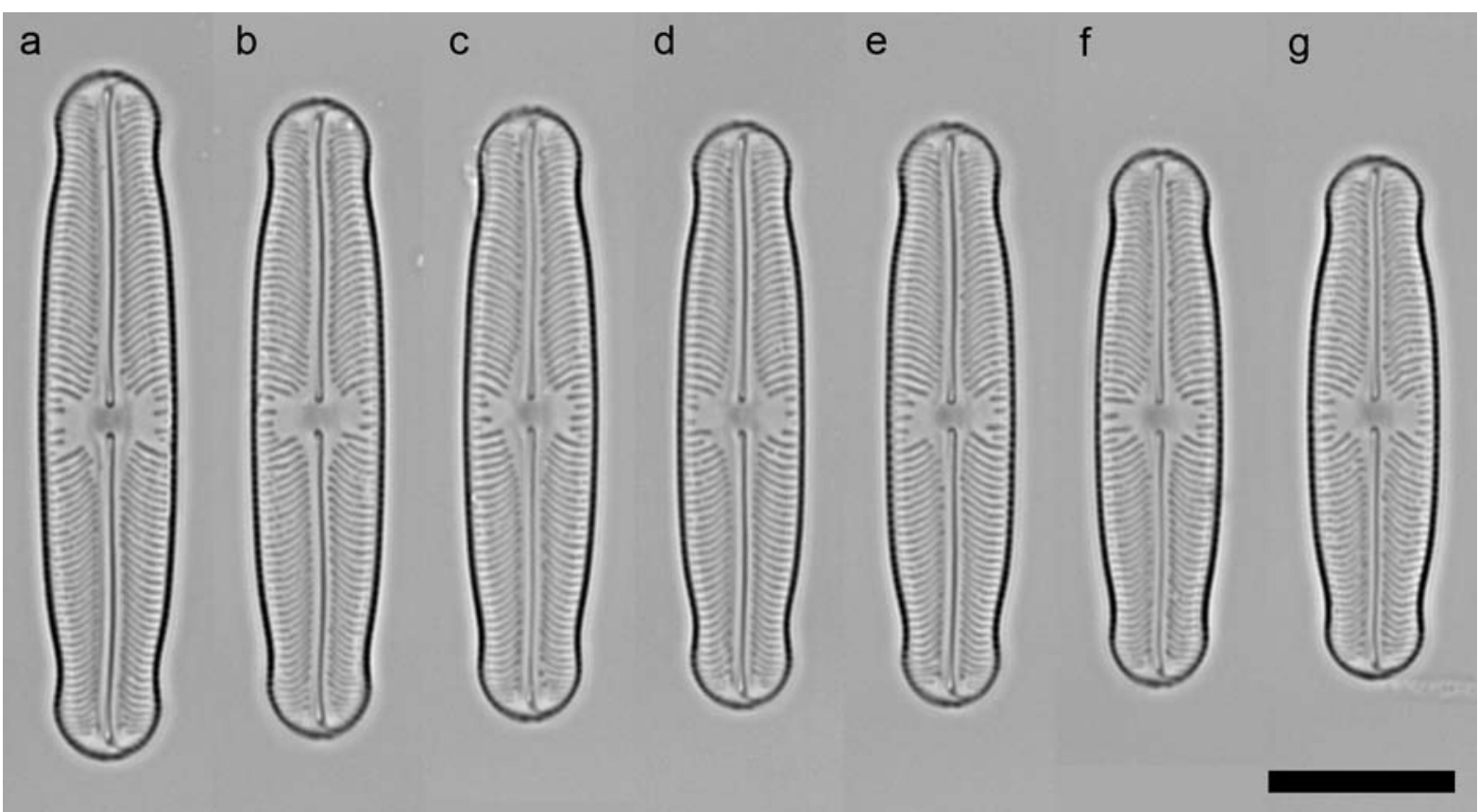

Fig. 55. Sellaphora [cf. laevissima K-LB] $\Phi$ 'barless capitate': Rae Loch; (a-g) slide E3672/1. Scale bar $=10 \mu \mathrm{m}$.

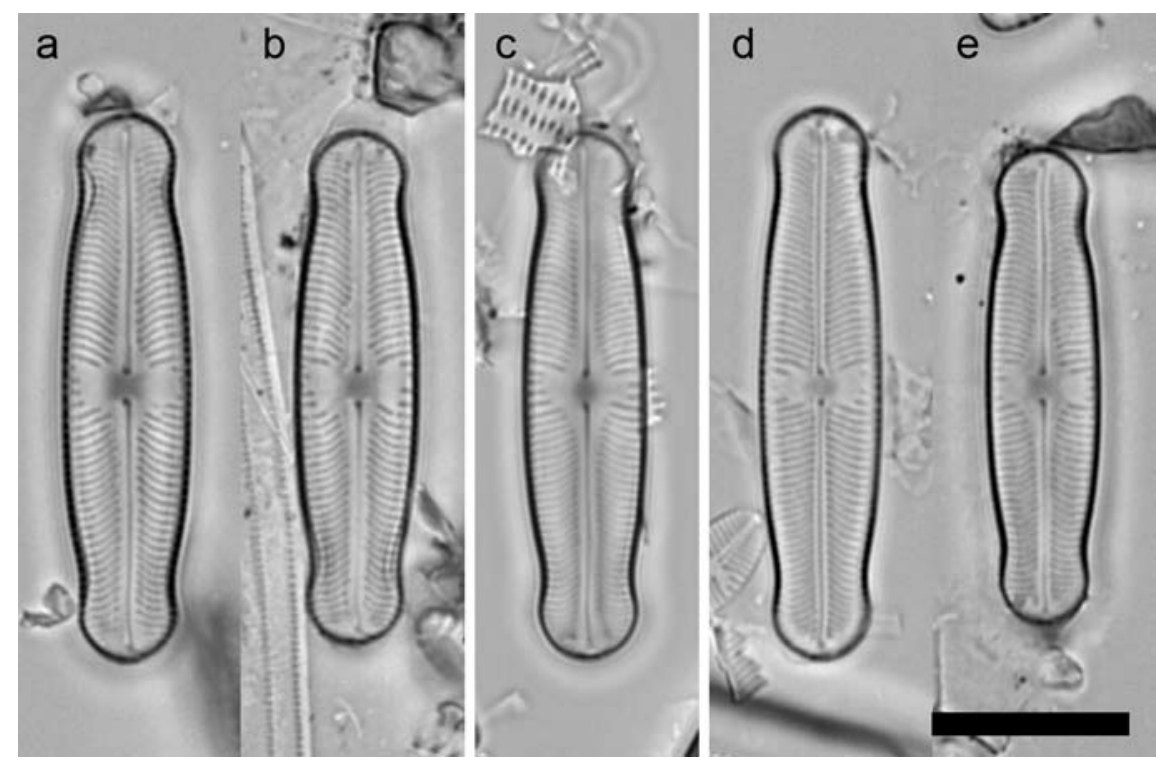

Fig. 56. Sellaphora [cf. laevissima K-LB] $\Phi$ 'mini-barless capitate': (a, b, e) Kates Cottage Pond, Sturston, slide '8 Aug 86'; (c, d) Balgavies Loch, slide E2619/1. Few specimens were found but even these were heterogeneous with respect to striation density, dimensions, and the width of the raphe sternum (coarser, wider specimens are placed on the left). Scale bar $=10 \mu \mathrm{m}$. 


\section{Discussion}

Status of the demes. Among the demes distinguished here, only the six species studied by MANN et al. (2004) - S. auldreekie, S. blackfordensis, S. capitata, S. lanceolata, S. pupula, and $S$. obesa - have been subjected to morphometric analysis, and then only from one wellstudied locality (Blackford Pond, Scotland). For these six, information is also available on valve ultrastructure, reproductive biology and isolation (MANN 1984, MANN et al. 1999, 2004), and for all except $S$. obesa we have molecular data from three genes from three different genomes that are consistent with the hypothesis that the six species are distinct and distantly related (BeHNKE et al. 2004, Evans et al. 2007, 2008, and unpublished). Published molecular data are also available for [bacillum] $\Phi$ 'rectangular', [pupula] $\Phi$ s 'small lanceolate', 'little', 'spindle', 'upland elliptical', 'urban elliptical', 'europa', 'small blunt-capitate', 'large', 'pseudocapitate', 'cf. capitate' and 'small capitate', and two demes of [laevissima] (Evans et al. 2007, 2008). However, sampling for molecular analysis is still too meagre and patchy to allow us to test fully the subjective, morphology-based classification of British Sellaphora that we have given here and it will probably be several years before enough isolates of all the demes are available.

In 1963, Ross said that "when a large number of populations [of $S$. pupula] are examined ... the various forms are found so to intergrade that there seems little justification for the taxonomic recognition of them at any level". As we worked through more samples for this paper, we became ever more sympathetic to the first part of Ross's comment because demes do often appear to intergrade, even though our mating experiments and molecular analyses have already indicated that Ross was wrong with respect to the interpretation of the variation pattern: taxonomic recognition is often necessary.

For example, our original detailed studies of Blackford Pond revealed the existence of a deme that we later recognized formally as $S$. auldreekie (MANN et al. 2004) and it was not usually difficult to separate $S$. auldreekie from other lanceolate [pupula] demes - such as S. lanceolata (Fig. 17), S. obesa (Fig. 20) and S. pupula (Fig. 30) - that grow alongside it in Blackford Pond and in other highly eutrophic lakes in Edinburgh. Subsequent studies, however, revealed three other small-celled demes - 'little', 'spindle' and 'tiny' - that have a similar elliptical shape and rostrate poles, and similar bow-tie-like central areas. These three differ a little from each other and from $S$. auldreekie in valve width and striation density, each being slightly larger and more coarsely striated than the next in the series; the easiest way to tell them apart is by the width of the rostrate ends, which varies from more than 4 $\mu \mathrm{m}$ in 'little' to $3 \mu \mathrm{m}$ in 'tiny' (Figs 32-35). Despite their morphological similarity, however, molecular data (Evans et al. 2007, 2008) suggest not only that these demes are distinct genetically but also that the relationship between 'spindle' + 'little' $\}$ and $S$. auldreekie is very distant (they seem to have diverged from each other millions of years ago). Although this is gratifying in showing that subtle differences in shape and size seem to have the significance we suggested in some earlier publications (e.g. MANN 1988a, MANN \& DROOP 1996, Mann \& ChePuRnov 2005), the practical effect of the discovery of 'spindle' and 'little' has been to make identification much more difficult, by narrowing the perceived morphological gaps between $S$. auldreekie and other demes with lanceolate valves.

Likewise, if all that was available to us were the populations of $S$. obesa from Blackford Pond (Fig. 20) and the 'corpulent' deme from Little Water (Fig. 18), it would be easy to conclude that two distinct species are present. However, better sampling has revealed a spectrum of 'obese' variants, from 'corpulent' to 'mini-obese'. These variants may or may not be separate species. In such cases, it seems best to adopt the precautionary principle that, if in doubt, it is better to separate than to merge, because dependent data can always be combined if a taxonomy proves to be too fine-grained, but never separated if it is too coarse. However, recognizing the members of the 'obese' series formally is premature.

Thus we frankly admit that, despite the wealth of images and supplementary data available to us, we are not sure that all of the distinctions we make here are valid and it is partly because of this that we do not make any formal taxonomic changes. The other reason is that we cannot yet provide molecular barcodes for all of the demes (see below). Particularly problematic morphological distinctions are those separating several of the $S$. [bacillum] phenodemes; those in the $S$. [pupula] phenodeme groups of 'corpulent''cf. corpulent'-obesa-'meso-obese'-mini-obese, 
pupula-'mouse', auldreekie-'tiny', 'dumbbell'blackfordensis, 'small blunt-capitate'-'pointy' and 'large'-'cf. large'; and those differentiating [laevissima] 'normal' and 'small'. Some demes may prove to be almost arbitrary segments from a continuum of genotypic or purely phenotypic variation; others may represent infrequent hybrid populations. Some of the problematic deme groups may consist of several separate biological species that partially or completely overlap in their morphological variation (i.e. semicryptic or fully cryptic species); others again may be quite separate but simply difficult to distinguish (pseudocryptic species), as apparently in the 'little''spindle'-auldreekie series.

But even if some of the demes prove not to be worth taxonomic recognition at any level, distinguishing them now is useful in pointing out and labelling aspects of the variation pattern that require further study: our survey is a staging post on the way to a classification, not a final solution, and is intended to stimulate new studies, especially where problematic entities occur together in the same localities. For example, $[$ pupula $] \Phi$ 'pseudocapitate' and $\Phi$ 'cf. capitate' (which are apparently distinct and not even sister taxa according to molecular data for three genes: Evans et al. 2007, 2008) co-exist in Threipmuir Reservoir and apparently also in the Loch of Clunie; these are probably the best places to start looking at whether the two can be separated morphologically and whether there is any interbreeding between them. Within $S$. [bacillum], there are fewer characters to use at the LM level than in S. [pupula], because of the simplicity of the central area and valve outline. Overall, [bacillum] $\Phi$ 'gibbous' seems well defined, and [bacillum] $\Phi$ 'button' is easily recognized by the combination of \pm rectangular outline, dense striation and a distinctive, button-like central area. However, $\Phi_{\mathrm{s}}$ 'oval', 'butter', 'buttermax' and 'radiate' seem to intergrade and in some cases it is difficult to separate $\Phi$ 'oval' from $\Phi$ 'rectangular'. In this complex, traditional taxonomy 'by eye' is simply inadequate. Molecular data are needed, and intensive morphometric and mating studies of [bacillum]-rich sites, e.g. Malham Tarn, Loch Leven, the Loch of Butterstone and some of the Shropshire meres (Table 4) will also be helpful.

Implications for traditional taxonomic practice. Our survey demonstrates that, in Sellaphora, there are considerable difficulties in using the tra- ditional methods for delineating and identifying diatom species, in which comparisons of shape and pattern are made 'visually'. This is still the approach adopted by almost all those who document the species diversity of diatoms, as can be confirmed by examining any volume of Iconographia diatomologica or Diatom Research. Two questions arise: (1) are these groups of species unusual among diatoms? (2) are there alternative approaches, that will provide less ambiguous results? In relation to (2), it is important not to overemphasize the difficulties - some of the Sellaphora demes are so clearly separated from any other that taxonomic recognition is unlikely to be controversial. Examples are [pupula] $\Phi$ 'lordly' and [laevissima] $\Phi$ 'perhibita' and several of the larger species described recently in Iconographia diatomologica. However, we doubt whether identifications based solely on LM morphology will ever be fully reliable within Sellaphora, especially among the demes that would formerly have been grouped together as 'Navicula pupula var. capitata' (Table 6). It will be interesting to examine whether ultrastructure can help discriminate between the demes, but we are not optimistic about the outcome. EM data (e.g. Schomman \& Archibald 1976-80, Mann et al. 2004, MetzelTIN et al. 2005, Levkov et al. 2007) have added remarkably little extra information so far in Sellaphora, except to clarify the true nature of features visible in LM. For example, SEM shows that the dark lines that border the raphe in 'small lanceolate, 'grooved lanceolate' 'spike' and 'lemon' are narrow grooves covered by half-length conopea (e.g. LevKov et al. 2007, pl. 106, fig. 20, and our unpublished observations). Elsewhere, however, SEM seems to add almost nothing to our understanding, although it does provide an extra metric character - areola density - which is certainly variable in Sellaphora: for example, the 'elliptical' demes are noticeably more coarsely areolate, even in LM.

Given the severe limitations of LM- and EM-based taxonomy in Sellaphora, we advocate greater use of molecular methods in Sellaphora, both for phylogenetics and also for barcoding, which allows identifications to be checked quickly and inexpensively. We have taken a step towards standard barcodes here by citing a published cox 1 barcode sequence for each deme where we are confident that we have correctly linked one or more natural populations to a molecularly-characterized clonal isolate. Like a type specimen, the 
Table 4. Distribution of [bacillum, (bac)] and [laevissima, (lae)] demes among localities.

\begin{tabular}{|c|c|c|c|c|c|c|c|c|c|c|c|c|c|c|}
\hline 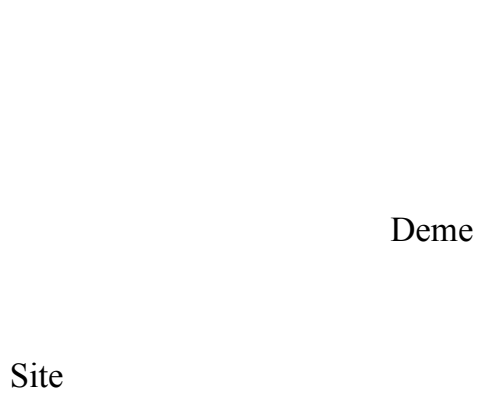 & 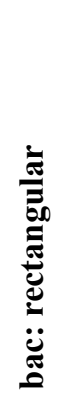 & 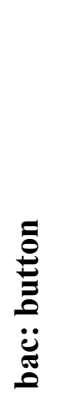 & 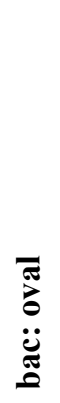 & 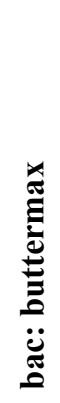 & 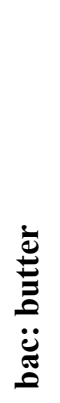 & 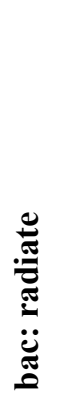 & 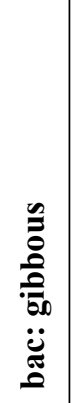 & 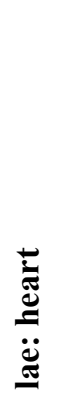 & 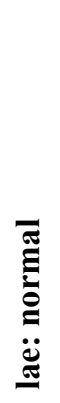 & 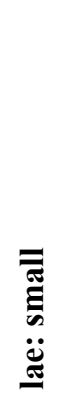 & 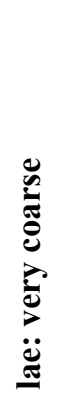 & 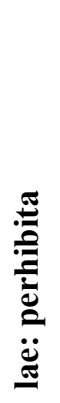 & 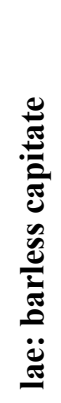 & 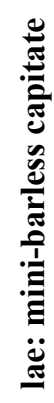 \\
\hline \multicolumn{15}{|l|}{ Loch Maree } \\
\hline \multicolumn{15}{|l|}{ Loch Tulla } \\
\hline \multicolumn{15}{|l|}{ Loch Lubnaig } \\
\hline \multicolumn{15}{|l|}{ Loch Venachar } \\
\hline \multicolumn{15}{|l|}{ Loch Voil } \\
\hline \multicolumn{15}{|l|}{ Loch Achray } \\
\hline Lake of Menteith & & & & & & & & & & + & & & & \\
\hline Balgavies Loch & + & & + & & & & & & + & & + & & & + \\
\hline \multicolumn{15}{|l|}{ Loch of Craiglush } \\
\hline Loch of Butterstone & & & & + & + & & & & + & & + & & & \\
\hline Loch of Drumellie & + & & & & & & & & & & + & & & \\
\hline Loch of Clunie & + & & + & & & & & & + & & + & & & \\
\hline Rae Loch & + & & & & & & & & + & & & & + & \\
\hline \multicolumn{15}{|l|}{ Fingask Loch } \\
\hline Monk Myre & + & & & & & & & & & & & & & \\
\hline Loch Leven & + & & & + & & + & + & & & & & & & \\
\hline Blackford Pond & + & & & & & & & & + & & & & & \\
\hline Dunsapie Loch & + & & & & & & & & + & & & & & \\
\hline Lochend Loch & + & & & & & & & & + & & + & & & \\
\hline Inverleith Pond & + & & & & & & & & & & & & & \\
\hline Royal Botanic Garden Pond & & & & & & & & & + & & & & & \\
\hline Mire, NE of Threipmuir Reservoir & & & & & & & & & + & & & & & \\
\hline Threipmuir Reservoir & + & & & & & & & + & + & & & & & \\
\hline Lindean Reservoir & & & & & & & & & + & & & & & \\
\hline Heart Moss, mire pools & & & & & & & & + & & & & & & \\
\hline Whinfell Tarn & & & + & & & & & & + & & & & & \\
\hline Little Water & & & & & & & & + & & & & & & \\
\hline Priest Pot & & & & & & & & & + & & & & & \\
\hline Malham Tarn & & + & + & & & & & & + & & & & & \\
\hline Budworth Mere & & & + & & & & & & & & & & & \\
\hline Pick Mere & & & + & & & & & & & & & & & \\
\hline Cole Mere & + & & + & & & & & & + & & + & & & \\
\hline Crose Mere & + & & + & & & & & & & & & & & \\
\hline Ellesmere & & & + & & & & & & + & & & & & \\
\hline Hanmer Mere & & & & & & & & & + & & & & & \\
\hline Oss Mere & & & & & & & & & + & & + & & & \\
\hline White Mere & & & + & & & & & & & & & & & \\
\hline Kates Cottage Pond, Sturston & + & & & & & & & & + & & & & & + \\
\hline Burton Pond, Petworth & + & & + & & & & & & + & & & & & + \\
\hline
\end{tabular}


barcode does not circumscribe a deme or species; rather, it helps to determine what name is applicable once a population or set of populations has been distinguished. However, molecular barcodes also have the advantage over type specimens that they are direct samples of the genotype and can be used immediately in preliminary estimates of genetic and phylogenetic relationships (e.g. Evans et al. 2007 and literature cited therein).

Is Sellaphora an unusually difficult genus? No satisfactory answer can yet be given to this question. Sellaphora pupula sensu lato has long been known to be highly variable and, once information became available indicating that this variation had a genetic basis and was accompanied by barriers to interbreeding (MANN 1984, 1989b), it was clear that several or many species would almost certainly need to be separated from it. The process of formally recognizing [pupula] demes as new species has already begun (Table 2) and will probably accelerate as the results of our survey are tested and further demes are discovered. However, it was not obvious to us before this survey that $S$. americana, S. bacillum and S. laevissima are also heterogeneous. Sellaphora americana and S. bacillum are single, undifferentiated species in KRAMMER \& LANGE-Bertalot's (1986) flora, and S. laevissima is split only into var. laevissima and var. perhibita. All three species have now been shown to be much more complicated entities than seemed to be the case 20 years ago (Table 2 and this paper). Looking outside Sellaphora, it seems that careful study of long-established diatom species usually reveals unexpected and significant diversity (e.g. MANN 1999, Lundholm et al. 2003, MANN \& Chepurnov 2005, Sarno et al. 2005, PoulíčKová \& ManN 2006, Trobajo et al. 2006, Амato et al. 2007). Thus, although $S$. [pupula] is probably unusual in its complexity, we see no evidence overall that the genus Sellaphora is a special case.

Distribution and co-occurrence. Tables 4 and 5 list where each deme was found during the study. No chemical analyses of the water column or sediments were made to accompany the epipelon samples and the ecological range of each deme remains to be determined. However, the Tables show several interesting features. (1) Most lakes contain several Sellaphora species, which appear to grow together in the same patches of epipelon, although our sampling methods would break up any centi- or decimetre-scale mosaic present in nature. (2) Certain demes, such as $S$. auldreekie, $S$. capitata, S. blackfordensis and $S$. lanceolata, often co-occur without loss of identity. (3) Some demes appear to be restricted to acid oligotrophic to dystrophic habitats, such as [pupula] $\Phi$ 'caput' (in Lochs Maree, Tulla, Lubnaig, Venachar and Craiglush), whereas others are characteristic of more alkaline, eutrophic waters, e.g. S. auldreekie, S. blackfordensis and [pupula] $\Phi$ 'mini-obese' (e.g. in Ellesmere and Oss Mere: non-contemporary water analyses for these lakes are available in the European Diatom Database at http://craticula.ncl.ac.uk/Eddi/jsp/). (4). The 'bacillum' and 'laevissima' groups seem to be absent or poorly represented in the most dilute, more acid habitats (the oligotrophic Lochs Maree, Tulla, Lubnaig, Venachar, Voil, Achray, Craiglush: PALmer \& RoY 2001), which broadly agrees with the ecological remarks given by Krammer \& LANGe-Bertalot (1986).

The frequent co-occurrence of several to many closely related and morphologically similar species is paradoxical, given conventional niche theory (cf. Hutchinson 1961), and a combination of population genetics, ecological field data and laboratory experiments will be needed to determine to what extent Sellaphora floras develop through 'niche assembly' or 'dispersal assembly' (Tilman 1982, HubBell 2001).

For some of the demes, we have commented on possible published records outside the British Isles, based principally on micrographs in the Iconographia diatomologica volumes. Despite the high quality of these illustrations, it is rarely possible to be confident that the diatoms shown are truly equivalent to any of our demes, but in several cases (e.g. [pupula] Фs 'lordly', 'grooved lanceolate', 'slender') the morphological similarity is convincing. It is noticeable that in most cases, the non-British records involve cool-temperate N Hemisphere localities. There are almost no overlaps between the British Sellaphora complement and the tropical or subtropical S American Sellaphora floras recorded by Metzeltin \& Lange-Bertalot $(1998,2007)$ and Metzeltin et al. (2005).

\section{Implications for recording and for biodiversity} estimates. The diatoms of the British Isles have been studied intensively for more than 150 years, resulting in several floras (Sмітн 1853, 1856, Hendey 1964, HartLey et al. 1996), many taxonomic and ecological papers containing species 


\begin{tabular}{|c|c|c|c|c|c|c|c|c|c|c|c|c|c|c|c|c|c|c|c|c|c|c|c|c|}
\hline әџยฺ!dвว-I[вus :dnd & & & & & & & + & + & & + & & & & & & & & + & & & & & & \\
\hline Indes :dnd & + & + & + & + & & & & & + & & + & & & + & & & & & & & & & & \\
\hline eqeł!des :dnd & & & & & & & & & & & & & & & & + & + & + & & & & & & \\
\hline 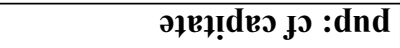 & & & & + & + & + & & & + & & + & + & & + & & + & & & & & & & + & \\
\hline әฺеұ!deวopnəsd :dnd & & & & & & & + & & & + & + & + & & & & & & & & & & & + & \\
\hline s!suәр.лојуәеIq :dnd & & & & & & & & + & & & & + & + & + & + & & + & + & + & & + & & + & + \\
\hline IIəqqunp :dnd & & & & & & & & & + & + & & + & & & & & & & & & & & & \\
\hline วoి.IrI J :dnd & + & & & & & + & & & & & & & & & & & & & & & & & & \\
\hline ว8..JP| :dnd & & & & & & & & & & + & & & & & & & & & & & & & + & \\
\hline sso.18: :dnd & & & & & & & & & & & & & & & & & & & & & & & + & \\
\hline 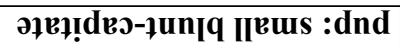 & + & & & + & & + & & & & & & & & & & & & & & & & & + & \\
\hline edo.Inə :dnd & & & & & & + & + & & & + & + & + & & & & & & & & & & & + & \\
\hline [вэ!ฺd!I|ə pur[dn :dnd & & & & & & & & & & & + & + & & & & & & & & & & & + & \\
\hline [ยว!]d!||ə ueq.In :dnd & & & & & & & & & & & & & & & & & + & & + & & + & & & \\
\hline Ku!̣ :dnd & & & & & & & & & & & & & & & & & & & & & & & + & \\
\hline ә!Үәә.хрIne :dnd & & & & & & & & & & & & + & & & & & + & + & + & & & & & \\
\hline गIpu!̣ds :dnd & & & & & & & & & & & & + & & & & & + & + & & & & & & \\
\hline əIभ!I :dnd & & & & & & & & & & & & & & & & & & & & & + & & & \\
\hline əsnou :dnd & & & & & & & & & & & & & & & & + & & & & & & & & \\
\hline rIndnd :dnd & & & & & & & & + & & + & + & + & + & & & + & + & + & & + & & & & \\
\hline Kłu!od :dnd & & + & & & & & & & & & & & & & & & & & & & & & & \\
\hline Крy.əəd :dnd & & & & & & & & & & & & & & & & & & & & & & + & & + \\
\hline Jouue :dnd & & & & & & & & & + & + & & & & & & & & & & & & & + & \\
\hline рәицә. :dnd & & & & & & & & & & & & & & & & & & & & & & & + & \\
\hline .әриә[s :dnd & + & & & & & & & & + & & & & & & & & & & & & & & & \\
\hline Kp! :dnd & & & & & & + & & & & & & & & & & & & & & & & & + & \\
\hline Кр! әр!м :dnd & + & & & & & & & & & & & & & & & & & & & & & & & \\
\hline әsəqo-!̣!̣u :dnd & & & & & & & & & & & + & + & & + & & + & & & & & & & + & \\
\hline әsәq0-osəu :dnd & & & & & & & & & & & & & & & & + & & & & & & & & \\
\hline esəqo :dnd & & & & & & & & + & & & & & + & & & & + & + & + & + & & & & \\
\hline 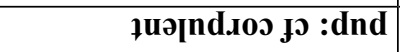 & & & & & & & & & & & + & + & & & & & & & & & + & & & + \\
\hline १uə|nd.ıos :dnd & & & & & & & & & & & & & & & & & & & & & & & & \\
\hline 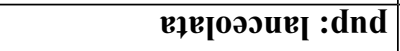 & & & & & & & & + & & & & & & & & & + & + & & & & & & \\
\hline uOUગ :dnd & & & & & & & & & & & & & & & & + & & & & & & & & \\
\hline 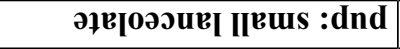 & & & & & & & & & & + & + & + & & & & + & + & + & & + & & & + & \\
\hline 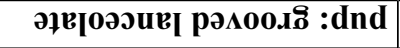 & & & & & & & & & + & + & & + & & + & & + & & & & & & & & \\
\hline әy!ds :dnd & & & & & & & & & & & & & & & & + & & & & & & & & \\
\hline KIp.IoI :dnd & & & & & & & & & & & & & & & & + & & & & & & & & \\
\hline $\begin{array}{l}\stackrel{\Xi}{0} \\
\stackrel{0}{0}\end{array}$ & 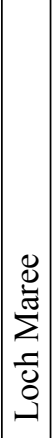 & 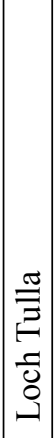 & 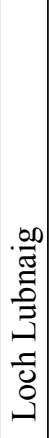 & 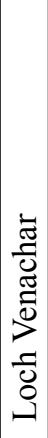 & $\begin{array}{c}= \\
\overline{2} \\
\overline{2} \\
\overline{0} \\
0 \\
0\end{array}$ & 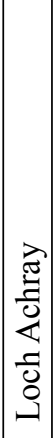 & 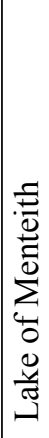 & 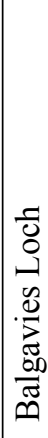 & 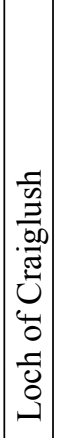 & 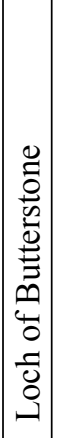 & 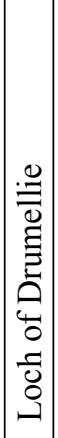 & 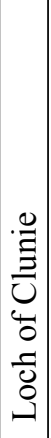 & 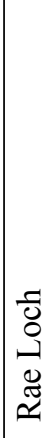 & 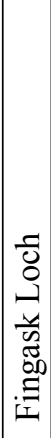 & 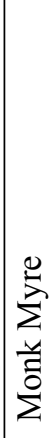 & 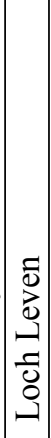 & 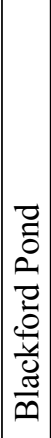 & 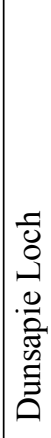 & 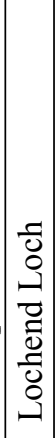 & 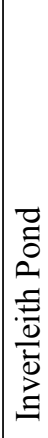 & 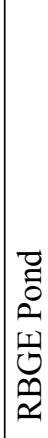 & 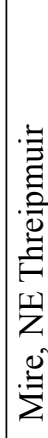 & 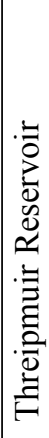 & 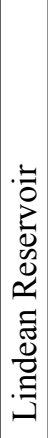 \\
\hline
\end{tabular}




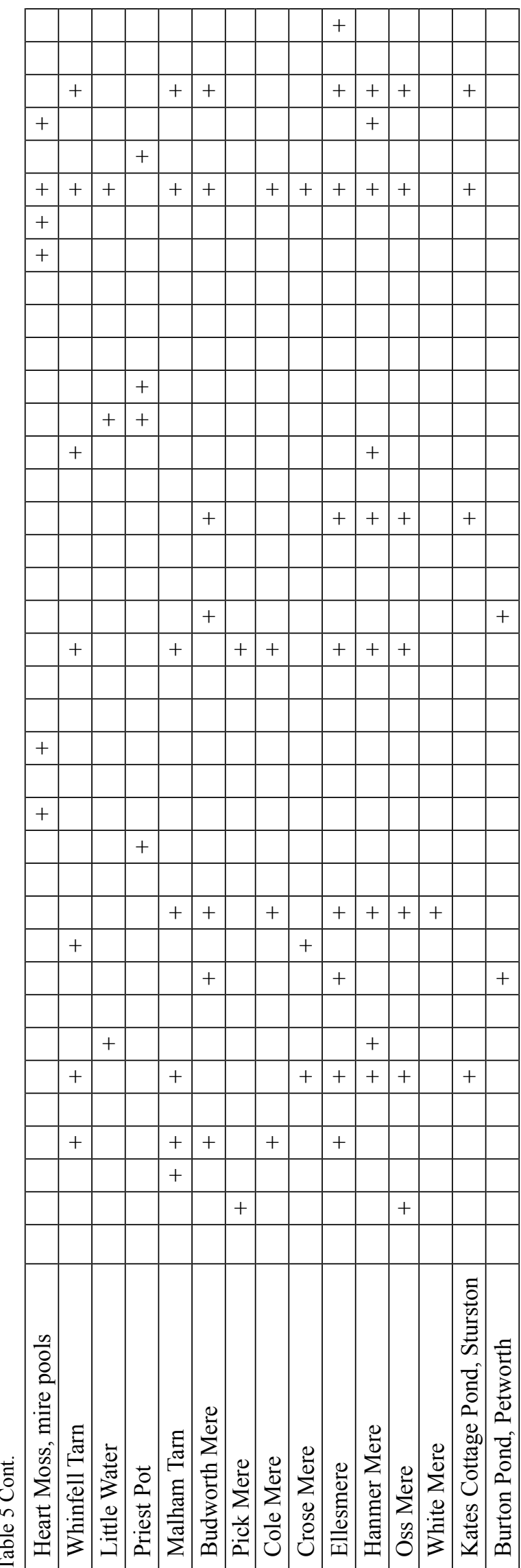

records (the earlier ones are listed by HaRTLEY 1986), and electronically stored data-sets from palaeoecological and ecological surveys (e.g. within the European Diatom Database). Given this activity, it is unlikely that many of the demes we illustrate here have not been seen before in British material: they have simply been identified under other names.

In a checklist of freshwater and marine diatoms, Hartley (1986) lists 15 species, varieties and forms of medium- and large-sized Navicula that would now be regarded as belonging to Sellaphora and these are listed in Table 6. We have not found any diatoms similar to the type of $S$. bacilloides illustrated by SimONSEN (1987, pl. 509, figs 1-5). Nor have we been able to study material of $S$. gregoryana (previously Navicula bacillum var. gregoryana), although we have a photograph (taken by A.J. Stickle) of a live specimen of what appears to be $S$. gregoryana, which was collected from Loch Leven in the mid 1980s. Loch Leven is the locality from which GREGORY provided the illustration (1856, pl. 1, fig. 4) of the slightly constricted [bacillum] diatom that was used by CLEVE \& GRUNOw $(1880$, p. 44$)$ as the basis for N. bacillum var. gregoryana Cleve \& GRUNOW. We made several new attempts in 2004-6 to collect material of S. gregoryana from Loch Leven but did not find it. The identities of $N$. bacillaris W. Greg. (GreGORY 1856, p. 7, pl. 1, fig. 24) and N. bacillum var. lepida (W. Greg.) Cleve (Gregory 1856, p. 7, pl. 1, fig. 25, as N. lepida) are unclear. Navicula pupula var. aquaeductae (KRASSKE) HuST., listed by HARTLEY, is now regarded as belonging to the genus Adlafia (Moser et al. 1998).

Instead of HARTLEY's 15 species, varieties and forms in 7 species (Table 6), we have distinguished 54 phenodemes. Even if we were to merge all those demes that might be regarded as problematic (see p. 44, top), our new total of larger Sellaphora OTUs would still be c. 40 and we remind readers that the current flora for central Europe (i.e. Krammer \& LANGe-BerTalot 1986, which tends to be used world-wide for identification, because it is the only completed modern flora available) lists only 4 species. Furthermore, it is unlikely that our catalogue is complete, even for Britain, because (1) we were still occasionally finding new demes as we completed this study in November 2007; (2) we were unable to check all the records of MANN \& DROOP (1996) and TAYLOR (1996); (3) we could not identify every valve photographed, because some were isolated indi- 
Table 6. Likely correspondence between older records of Sellaphora species according to the British checklist (HARTLEY 1986) and the phenodemes described here. We assume that the names in HARTLEY's list were used in the sense applied by HustedT (1930), except for N. bacillaris, Navicula bacillum var. lepida and N. perhibita which were not included. Before 1986, Navicula laevissima was called either N. bacilliformis or N. wittrockii by most authors.

\begin{tabular}{|c|c|}
\hline Listing in HaRTLEY (1986) & Corresponding phenodemes \\
\hline Navicula americana & $\begin{array}{l}\text { Sellaphora americana } \Phi \text { 'wide' } \\
\text { Sellaphora americana } \Phi \text { 'narrow' }\end{array}$ \\
\hline Navicula bacillaris & identity unclear \\
\hline Navicula bacilloides & not found in this study \\
\hline Navicula bacillum & $\begin{array}{l}\text { Sellaphora }[\text { bacillum }] \Phi \text { 'rectangular' } \\
\text { Sellaphora }[\text { bacillum } \Phi \text { 'button' } \\
\text { Sellaphora }[\text { bacillum } \Phi \text { 'oval' } \\
\text { Sellaphora }[\text { bacillum }] \Phi \text { 'buttermax' } \\
\text { Sellaphora }[\text { bacillum }] \Phi \text { 'butter' } \\
\text { Sellaphora }[\text { bacillum }] \Phi \text { 'radiate' } \\
\text { Sellaphora }[\text { bacillum } \Phi \text { 'gibbous' }\end{array}$ \\
\hline Navicula bacillum var. gregoryana & not found in this study \\
\hline Navicula bacillum var. lepida & identity unclear \\
\hline Navicula perhibita & Sellaphora $[$ laevissima $] \Phi$ 'perhibita \\
\hline Navicula pupula & 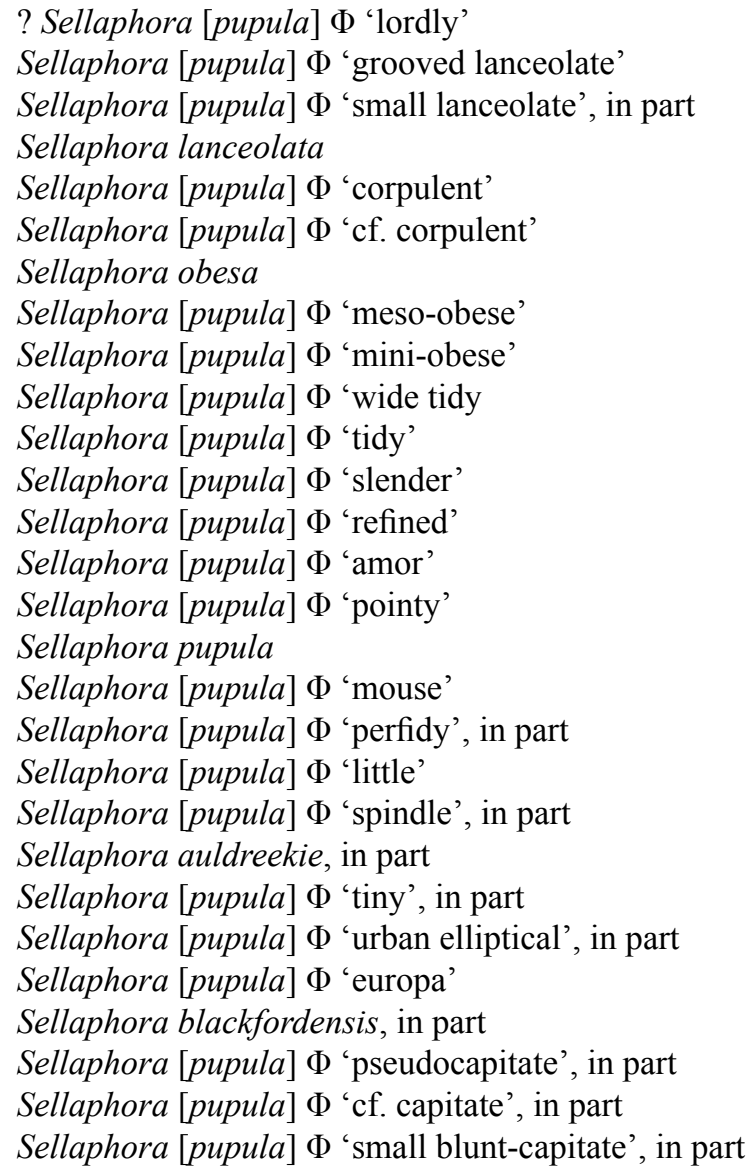 \\
\hline
\end{tabular}


Table 6 Cont

\begin{tabular}{|c|c|}
\hline Navicula pupula fo. rostrata & $\begin{array}{l}\text { Sellaphora [pupula] } \Phi \text { 'spike' } \\
\text { Sellaphora [pupula] } \Phi \text { 'small lanceolate', in part } \\
\text { Sellaphora [pupula] } \Phi \text { 'lemon' } \\
\text { Sellaphora [pupula] } \Phi \text { 'spindle', in part } \\
\text { Sellaphora auldreekie, in part } \\
\text { Sellaphora }[\text { pupula] } \Phi \text { 'tiny', in part }\end{array}$ \\
\hline Navicula pupula var. capitata & $\begin{array}{l}\text { Sellaphora [pupula] } \Phi \text { 'gross' } \\
\text { Sellaphora }[\text { pupula] } \Phi \text { 'large', in part } \\
\text { Sellaphora }[\text { pupula] } \Phi \text { 'dumbbell' } \\
\text { Sellaphora blackfordensis, in part } \\
\text { Sellaphora }[\text { pupula] } \Phi \text { 'pseudocapitate', in part } \\
\text { Sellaphora }[\text { pupula] } \Phi \text { 'cf. capitate', in part } \\
\text { Sellaphora capitata } \\
\text { Sellaphora }[\text { pupula] } \Phi \text { 'caput' } \\
\text { Sellaphora }[\text { pupula] } \Phi \text { 'small capitate' }\end{array}$ \\
\hline Navicula pupula var. elliptica & $\begin{array}{l}\text { Sellaphora }[\text { pupula }] \Phi \text { 'urban elliptical', in part } \\
\text { Sellaphora }[\text { pupula }] \Phi \text { 'upland elliptical' } \\
\text { Sellaphora }[\text { pupula }] \Phi \text { 'small blunt-capitate', in part }\end{array}$ \\
\hline Navicula pupula var. mutata & $\begin{array}{l}\text { Sellaphora auldreekie, in part } \\
\text { Sellaphora }[\text { pupula }] \Phi \text { 'tiny', in part }\end{array}$ \\
\hline Navicula pupula var. pseudopupula & $\begin{array}{l}\text { Sellaphora }[\text { pupula }] \Phi \text { 'small blunt-capitate', in part } \\
\text { Sellaphora }[\text { pupula }] \Phi \text { 'perfidy', in part }\end{array}$ \\
\hline Navicula pupula var. rectangularis & $\begin{array}{l}\text { Sellaphora }[\text { pupula }] \Phi \text { 'large', in part } \\
\text { Sellaphora }[\text { pupula }] \Phi \text { 'cf. large' }\end{array}$ \\
\hline Navicula laevissima & $\begin{array}{l}\text { Sellaphora [laevissima] } \Phi \text { 'heart' } \\
\text { Sellaphora [laevissima] } \Phi \text { 'normal' } \\
\text { Sellaphora [laevissima] } \Phi \text { 'small' } \\
\text { Sellaphora [laevissima] } \Phi \text { 'very coarse' }\end{array}$ \\
\hline- & $\begin{array}{l}\text { Sellaphora [laevissima] } \Phi \text { 'barless capitate' } \\
\text { Sellaphora [laevissima] } \Phi \text { 'mini-barless capitate' }\end{array}$ \\
\hline
\end{tabular}

viduals whose life-cycle variation could not be estimated with confidence; (4) we restricted ourselves almost exclusively to our own samples of harvested epipelon, to maximize the chances of finding many clean examples of each deme per slide (many samples of surface sediment are available from ecological and palaeoecological studies, but in these epipelon is diluted by allochthonous plankton and periphyton, as well as by the inorganic sediment itself); and (5) we probably did not explore the full ranges (in the British Isles) of the environmental parameters that control the ecology of Sellaphora species. However, despite all the problems, we can be confident in one conclusion: there are many more distinct entities (putative species) in Sellaphora than has previously been recognized, even in a well-studied country like the United Kingdom. The question that arises next is whether this has any practical effect, for example in interpreting previous records and making new ones.

By happy chance, HARTLEY's (1986) checklist provides an opportunity to examine the value and meaning of earlier published records, because it predates the publication of the new standard European flora by KRAMMER \& LANGE-BERTALOT (1986). Most of HARTLEY's records of freshwater diatoms will therefore have been made using a single consistent taxonomy, namely that standardized by Hustedt (e.g. 1930, 1961). So, by examining the descriptions and illustrations given by Hustedt (op. cit.), we can relate our demes to the records of 'Navicula' species and varieties collated by Hartley and this is done in Table 6. If our identifications are agreed to be reasonable (Hustedt 1930 provided no metric data but only a single illustration and a verbal description for the 'infraspecific' taxa of S. pupula, so that diatomists 
had to rely on shape and pattern alone for identifications), then it is clear that no previous British records of any of the larger Sellaphora species can be interpreted in the context of the phenodemes recognized here, except for [laevissima] $\Phi$ 'perhibita'. Several of the demes have probably been identified as different infraspecific taxa, depending on which stage of the life cycle was observed and who was observing it.

We noted above that it is difficult to find convincing equivalents to our demes among good illustrations of Sellaphora species from non-British sites. It should be obvious from this and Table 6 that the biogeography of Sellaphora species and varieties cannot be determined from the literature. Published records, like those of Sellaphora pupula var. elliptica (Hust.) BuKhtiYarova used during the provocative analysis of diatom biogeography by FINLAY et al. (2002), mean almost nothing. It seems probable to us that the same is likely to be true for many other diatoms, but each case must be evaluated on its own merits. Molecular data (Evans et al. 2007) suggest that the [pupula] group is not monophyletic and that the [pupula][bacillum] clade has been diversifying for well over 10 million years. Progress in understanding the ecology and biogeography of diatoms is unlikely to be made if such units as Sellaphora [pupula] are used as the basis of recording.

\section{Acknowledgements}

We thank all those who have worked with us on Sellaphora during the last 25 years, including Alan Stickle, Neil Taylor, Stephen Droop, Bill Marshall, Liz Jamieson, Alex Prendergast, Frieda Christie, Carolyn Guihal, Dr. Victor Chepurnov, Dr. Alexandra Wortley, Dr. Micha Bayer, Dr. Gillian Simpson, Dr. Sarah McDonald, Dr. Anke Behnke, Prof. Dr. Thomas Friedl, Dr. Regine Jahn and Assoc. Prof. Aloisie Poulíčková, who encouraged us to complete the phenodeme catalogue. We are also grateful to Prof. Frank Round for much encouragement and discussion over many years; Dr. Nigel Cameron, Dr. David Jewson and the late Bernard Hartley for slide collections; and Prof. Dr. Wim Vyverman, Prof. Dr. Koen Sabbe, Dr. Wiebe Kooistra, Dr. Marina Montresor, Dr. Alberto Amato and Dr. Rosa Trobajo for discussion and many interesting insights into species delimitation and evolution in diatoms. The careful review of an anonymous referee was helpful and much appreciated.

\section{References}

Aboal, M., Álvarez-Cobelas, M., Cambra, J. \& Ector, L. (2003): Floristic list of the non marine diatoms (Bacillariophyceae) of Iberian Peninsula, Balearic Islands and Canary Islands. Updated taxonomy and bibliography. - In: WITKOwSKI, A. (ed.): Diatom monographs 4: 1-639, A.R.G. Gantner, Ruggell, Liechtenstein.

Amato, A., Kooistra, W.H.C.F., Levialdi Ghiron, J.H., Mann, D.G., Pröschold, T. \& Montresor, M. (2007): Reproductive isolation among sympatric cryptic species in marine diatoms. - Protist 158: 193-207.

Andresen, N.A., Stoermer, E.F. \& Kreis, R.G. JR. (2000): New nomenclatural combinations referring to diatom taxa which occur in the Laurentian Great Lakes of North America. - Diatom Res. 15: 409-411.

BArber, H.G. \& Haworth, E.Y. (1981): A guide to the morphology of the diatom frustule, with a key to the British freshwater genera. - Scient. Publs, Freshwat. Biol. Ass. 44: 1-112.

Bayer, M.M, Droop, S.J.M. \& ManN, D.G. (2001): Digital imaging as a tool in phycological research, with especial reference to microalgae. - Phycol. Res. 49: 263-274.

Behnke, A., Friedl, T., Chepurnov, V.A. \& Mann, D.G. (2004): Reproductive compatibility and rDNA sequence analyses in the Sellaphora pupula species complex (Bacillariophyta). - J. Phycol. 40: 193-208.

Cleve, P.T. (1894): Synopsis of the naviculoid diatoms, Part 1. - K. Svenska Vetensk.-Akad. Handl., ser. 2, 26(2): 1-194.

Cleve, P.T. \& Grunow, A. (1880): Beiträge zur Kenntniss der arctischen Diatomeen. - K. svenska Vetensk.-Akad. Handl. 17(2): 1-121.

Cleve-Euler, A. (1953): Die Diatomeen von Schweden und Finnland. Teil III. Monoraphideae, Biraphideae 1. - K. svenska Vetenskaps-Akad. Handl., ser. 4, 4(5): 1-255.

Edgar, L.A. (1980): Fine structure of Caloneis amphisbaena (Bacillariophyceae). - J. Phycol. 16: 62-72.

EhrenBerg, C.G. (1839): Über die Bildung der Kreidefelsen und des Kreidemergels durch unsichtbare Organismen. - Abh. Königl. Akad. Wiss. Berlin 1838: 59-147.

EhrenberG, C.G. (1843): Verbreitung und Einfluss des mikroskopischen Lebens in Süd- und NordAmerika. - Abh. Königl. Akad. Wiss. Berlin 1841: 291-446.

Evans, K.M., Wortley, A.H. \& Mann, D.G. (2007): An assessment of potential diatom "barcode" genes (cox $1, r b c \mathrm{~L}, 18 \mathrm{~S}$ and ITS rDNA) and their effectiveness in determining relationships in Sellaphora (Bacillariophyta). - Protist 158: 
349-364.

Evans, K.M., Wortley, A.H., Simpson, G.E., ChepURNOV, V.A. \& MANN, D.G. (2008): A molecular systematic approach to explore diversity within the Sellaphora pupula species complex (Bacillariophyta). - J. Phycol. 44: 215-231.

Finlay, B.J., Monaghan, E.B. \& Maberly, S.C. (2002): Hypothesis: The rate and scale of dispersal of freshwater diatom species is a function of their global abundance. - Protist 153: 261-273.

Geitler, L. (1932): Der Formwechsel der pennaten Diatomeen (Kieselalgen). - Arch. Protistenk. 78: 1-226.

GeitLer, L. (1973): Bewegungs- und Teilungsverhalten der Chromatophoren von Eunotia pectinalis var. polyplastidica und anderer Eunotia-Arten bei der Zellteilung. - Österr. Bot. Z. 122: 185-194.

Germain, H. (1981): Flore des Diatomées. Diatomophycées eaux douces et saumâtres du Massif Armoricain et des contrées voisines d'Europe occidentale. - 444 pp., Boubée, Paris.

Gilmour, J.S.L. \& Heslop-Harrison, J. (1954): The deme terminology and the units of micro-evolutionary change. - Genetica 27: 147-161.

Gregory, W. (1854): Notice of the new forms and varieties of known forms occurring in the diatomaceous earth of Mull; with remarks on the classification of the Diatomaceae. - Quart. J. microsc. Sci., new series, 2: 90-100.

GregORY, W. (1856): Notice of some new species of British fresh-water Diatomaceae. - Quart. J. microsc. Sci., new series, 4: 1-14.

Guillard, R.R.L. \& Lorenzen, C.L. (1972): Yellowgreen algae with chlorophyllide c. - J. Phycol. 8: $10-14$.

Hartley, B. (1986): A check-list of the freshwater, brackish and marine diatoms of the British Isles and adjoining coastal waters. - J. mar. biol. Ass. U.K. 66: 531-610.

Hartley, B., Barber, H.G., Carter, J.R. \& Sims, P.A. (1996): An atlas of British diatoms. - 601 pp., Biopress, Bristol.

Hendey, N.I. (1964): An introductory account of the smaller algae of British coastal waters. V. Bacillariophyceae (Diatoms). - 317 pp., Her Majesty's Stationery Office, London.

Houk, V. (2003): Atlas of freshwater centric diatoms with a brief key and descriptions. Part 1. Melosiraceae, Orthoseiraceae, Paraliaceae and Aulacoseiraceae. - Czech Phycology, Suppl. 1: $1-112$.

HubBell, S.P. (2001): The unified neutral theory of biodiversity and biogeography. -375 pp., Princeton University Press, Princeton.

Hustedt, F. (1911): Beiträge zur Algenflora von Bremen. IV. Bacillariaceen aus der Wümme. - Abh. Naturw. Ver. Bremen 20: 257-315.

Hustedt, F. (1930): Bacillariophyta. - In: Pascher, A. (ed.): Die Süsswasser-Flora Mitteleuropas 10/ 2: 1-466, G. Fischer, Jena.

Hustedt, F. (1937-1939): Systematische und ökologische Untersuchungen über die Diatomeenflora von Java, Bali und Sumatra nach dem Material der Deutschen Limnologischen Sunda-Expedition. - Arch. Hydrobiol., Suppl. 15: 131-177, 187-295, 393-506, 638-790; Suppl. 16: 1-155, 274-394.

Hustedt, F. (1950): Die Diatomeenflora norddeutscher Seen mit besonderer Berücksichtigung des holsteinischen Seengebiets. V-VII. Seen in Mecklenburg, Lauenburg und Nordostdeutschland. - Arch. Hydrobiol. 43: 329-458.

Hustedt, F. (1961): Die Kieselalgen Deutschlands, Österreichs und der Schweiz unter Berücksichtigung der übrigen Länder Europas sowie der angrenzenden Meeresgebiete. - In: RABENHORST L. (ed.): Kryptogamenflora von Deutschland, Österreich und der Schweiz 7/1: 1-160, Akademische Verlagsgesellschaft, Leipzig.

Hustedt, F. (1962): Die Kieselalgen Deutschlands, Österreichs und der Schweiz unter Berücksichtigung der übrigen Länder Europas sowie der angrenzenden Meeresgebiete. - In: RABENHORST L. (ed.): Kryptogamenflora von Deutschland, Österreich und der Schweiz 7/2: 161-348, Akademische Verlagsgesellschaft, Leipzig.

Hutchinson, G.E. (1961): The paradox of the plankton. - Amer. Nat. 95: 137-145.

Johansen, J.R., Lowe, R.L., Gomez, S.R., Kociolek, J.P. \& Makosky, S.A. (2004): New algal species records for the Great Smoky Mountains National Park, USA, with an annotated checklist of all reported algal species for the Park. Algological Studies 111: 17-44.

Jones, H.M., Simpson, G.E., Stickle, A.J. \& Mann, D.G. (2005): Life history and systematics of Petroneis (Bacillariophyta), with special reference to British waters. - Eur. J. Phycol. 40: 43-71.

Krammer, K. \& Lange-Bertalot, H. (1985): Naviculaceae. Neue und wenig bekannte Taxa, neue Kombinationen und Synonyme sowie Bemerkungen zu einigen Gattungen. - Bibliotheca diatomol. 9: 1-230.

Krammer, K. \& Lange-Bertalot, H. (1986): Bacillariophyceae 1. Teil: Naviculaceae. - In: EtTL, H., Gerloff, J., Heynig, H. \& Mollenhauer, D. (eds): Süsswasserflora von Mitteleuropa, 2/1: 1-876, G. Fischer, Stuttgart \& New York.

Krasske, G. (1923): Die Diatomeen des Casseler Bekkens und seiner Randgebirge nebst einigen wichtigen Funden aus Niederhessen. - Bot. Arch. 3: 185-209.

Krasske, G. (1929): Beiträge zur Diatomeenflora Sachsens. - Bot. Arch. 27: 348-380.

KüTZING, F.T. (1844): Die kieselschaligen Bacillarien 
oder Diatomeen. - 152 pp., W. Köhne, Nordhausen.

Lange-Bertalot, H. \& Genkal, S.I. (1999): Diatomeen aus Sibirien I. Inseln im Arktischen Ozean (Yugorsky-Shar Strait). - In: LANGe-Bertalot, H. (ed.): Iconographia diatomologica. Annotated diatom micrographs. Vol. 6. Phytogeography-Diversity-Taxonomy. - 2-271pp., Koeltz Scientific Books, Koenigstein.

Lange-Bertalot, H. \& Metzeltin, D. (1996): Oligotrophie-Indikatoren. 800 Taxa repräsentativ für drei diverse Seen-Typen. Kalkreich-oligodystroph-schwach gepuffertes Weichwasser. - In: LANGe-Bertalot, H. (ed.): Iconographia diatomologica. Annotated diatom micrographs. Vol. 2. Ecology-Diversity-Taxonomy. - 1-390pp., Koeltz Scientific Books, Königstein, Germany.

Lange-Bertalot, H. \& Moser, G. (1994): Brachysira. Monographie der Gattung. - Bibliotheca diatomol. 29: 1-212.

Lange-Bertalot, H., Külbs, K., Lauser, T., NörpelSchempr, M. \& Willmann, M. (1996): Dokumentation und Revision der von Georg Krasske bechriebenen Diatomeen-Taxa. - In: LANGEBERTALOT, H. (ed.): Iconographia diatomologica. Vol. 3. Annotated diatom micrographs, Taxonomy. - 1-358pp., Koeltz Scientific Books, Königstein, Germany.

Lange-Bertalot, H., Cavacini, P., Tagliaventi, N. \& Alfinito, S. (2003): Diatoms of Sardinia. Rare and 76 new species in rock pools and other ephemeral waters. - In: LANGe-Bertalot, H. (ed.): Iconographia diatomologica. Annotated diatom micrographs. Vol. 12. BiogeographyEcology-Taxonomy. - 1-438pp., A.R.G. Gantner, Ruggell, Liechtenstein.

Levkov, Z., Nakov, T. \& Metzeltin, D. (2006): New species and combination from the genus Sellaphora Mereschkowsky from Macedonia. - Diatom Res. 21: 297-312.

Levkov, Z., Krstic, S., Metzeltin, D. \& Nakov, T. (2007): Diatoms of lakes Prespa and Ohrid. About 500 taxa from ancient lake system. In: LANGe-Bertalot, L. (ed.): Iconographia diatomologica. Annotated diatom micrographs. Vol. 16. Biogeography-Ecology-Taxonomy. 1-611pp., A.R.G. Gantner, Ruggell, Liechtenstein.

Lundholm, N., Moestrup, Ø., Hasle, G.R. \& Hoef-EmDEN, K. (2003): A study of the Pseudo-nitzschia pseudodelicatissima/cuspidata complex (Bacillariophyceae): what is P. pseudodelicatissima? - J. Phycol. 39: 797-813.

ManN, D.G. (1984): Observations on copulation in $\mathrm{Na}$ vicula pupula and Amphora ovalis in relation to the nature of diatom species. - Ann. Bot. 54: 429-438.

ManN, D.G. (1988a): The nature of diatom species: analysis of sympatric populations. - In: Round, F.E. (ed.): Proceedings of the 9th International Diatom Symposium. - 317-327pp., Biopress, Bristol and O. Koeltz, Koenigstein.

Mann, D.G. (1988b): Why didn't Lund see sex in $A s-$ terionella? A discussion of the diatom life cycle in nature. - In: Round, F.E. (ed.): Algae and the Aquatic Environment. - 383-412pp., Biopress, Bristol.

Mann, D.G. (1989a): The diatom genus Sellaphora: separation from Navicula. - Br. Phycol. J. 24: $1-20$.

ManN, D.G. (1989b): The species concept in diatoms: evidence for morphologically distinct, sympatric gamodemes in four epipelic species. - Plant Syst. Evol. 164, 215-237.

ManN, D.G. (1996): Chloroplast morphology, movements and inheritance in diatoms. - In CHAUDHARY, B.R. \& Agrawal, S.B. (eds): Cytology, genetics and molecular biology of algae. 249-274pp., SPB Academic Publishing, Amsterdam.

Mann, D.G. (1999): The species concept in diatoms (Phycological Reviews 18). - Phycologia 38: 437-495.

ManN, D.G. (2001): The systematics of the Sellaphora pupula complex: typification of $S$. pupula. In: JAHN, R., Kociolek, J.P., Witkowski, A. \& Compère, P. (eds): Lange-Bertalot-Festchrift. Studies on diatoms, dedicated to Prof. Dr. Dr. h.c. Horst Lange-Bertalot on the occasion of his 65th birthday. - 225-241pp., A.R.G. Gantner, Ruggell, Liechtenstein.

Mann, D.G. \& Chepurnov, V.A. (2005): Auxosporulation, mating system, and reproductive isolation in Neidium (Bacillariophyta). - Phycologia 44: 335-350.

ManN, D.G. \& Droop, S.J.M. (1996): Biodiversity, biogeography and conservation of diatoms. Hydrobiologia 336: 19-32.

Mann, D.G. \& KocioleK, J.P. (1990): The species concept in diatoms: report on a workshop. - In: SIMOLA, H. (ed.): Proceedings of the 10th International Diatom Symposium, pp. 577-583, Koeltz Scientific Books, Koenigstein.

Mann, D.G., Chepurnov, V.A. \& Droop, S.J.M. (1999): Sexuality, incompatibility, size variation, and preferential polyandry in natural populations and clones of Sellaphora pupula (Bacillariophyceae). - J. Phycol. 35: 152-170.

Mann, D.G., Chepurnov, V.A. \& Idei, M. (2003): Mating system, sexual reproduction and auxosporulation in the anomalous raphid diatom Eunotia (Bacillariophyta). - J. Phycol. 39: 1067-1084.

Mann, D.G., McDonald, S.M., Bayer, M.M., Droop, S.J.M., Chepurnov, V.A., Loke, R.E., Ciobanu, A. \& DU BuF, J.M.H. (2004): Morphometric analysis, ultrastructure and mating data provide 
evidence for five new species of Sellaphora (Bacillariophyceae). - Phycologia 43: 459-482.

Mann, D.G., BaYer, M.M., Droop, S.J.M., Hicks, Y.A., Marshall, A.D., Martin, R.R. \& Rosin, P.L. (2007): New methods for preparing, imaging and typifying desmids (Chlorophyta, Zygnematophyceae), including extended depth of focus and 3-D reconstruction. - Phycologia 46: $29-45$.

Meduin, L.K. \& Round, F.E. (1986): Taxonomic studies of marine gomphonemoid diatoms. - Diatom Res. 1: 205-225.

Mereschrowsky, C. (1902): On Sellaphora, a new genus of diatoms. - Ann. Mag. Nat. Hist., series 7, 9: 185-195.

Mereschkowsky, C. (1905): Über Natur und Ursprung der Chromatophoren im Pflanzenreiche. - Biol. Centralbl. 25: 593-604.

Metzeltin, D. \& Lange-Bertalot, H. (1998): Tropische Diatomeen in Südamerika I. 700 überwiegend wenig bekannte oder neue Taxa repräsentativ als Elemente der neotropischen Flora. - In: LANGe-Bertalot, H. (ed.): Iconographia diatomologica. Annotated diatom micrographs. Vol. 5. Diversity-Taxonomy-Geobotany. 1-695pp., Koeltz Scientific Books, Königstein, Germany.

Metzeltin, D. \& Lange-Bertalot, H. (2002): Diatoms from the "Island Continent" Madagascar. - In: LANGE-Bertalot, H. (ed.): Iconographia diatomologica. Annotated diatom micrographs. Vol. 11. Taxonomy-Biogeography-Diversity. - 1-286pp., A.R.G. Gantner, Ruggell, Liechtenstein.

Metzeltin, D. \& Lange-Bertalot, H. (2007): Tropical diatoms of South America II. Special remarks on biogeographic disjunction. - In: LANGE-BERTALOT, H. (ed.): Iconographia diatomologica. Annotated diatom micrographs. Diversity-Taxonomy-Biogeography 18: 1-877, A.R.G. Gantner, Ruggell, Liechtenstein.

Metzeltin, D. \& García-Rodríguez, F. (2003): Las Diatomeas Uruguayas. - 207 pp., Facultad de Ciencias, Universidad de la República, Montevideo, Uruguay.

Metzeltin, D. \& Witkowski, A. (1996): Diatomeen der Bären-Insel. Süsswasser- and marine Arten. - In: Lange-Bertalot, H. (ed.): Iconographia diatomologica. Annotated diatom micrographs. Vol. 4. Ecology-Hydrology-Taxonomy. 3-232pp., Koeltz Scientific Books, Koenigstein, Germany.

Metzeltin, D., Lange-Bertalot, H. \& García-RoDRÍGUEZ, F. (2005): Diatoms of Uruguay. Compared with other taxa from South America and elsewhere. - In: Lange-Bertalot, H. (ed.): Iconographia diatomologica. Annotated diatom micrographs. Vol. 15. Taxonomy-Biogeogra- phy. -736 pp., Diversity. A.R.G. Gantner, Ruggell, Liechtenstein.

Moser, G., Steindorf, A. \& Lange-Bertalot, H. (1995): Neukaledonien Diatomeenflora einer Tropeninsel. Revision der collection Maillard und Untersuchung neuen Materials. - Bibliotheca diatomol. 32: 1-340.

Moser, G., Lange-Bertalot, H. \& Metzeltin, D. (1998): Insel der Endemiten. Geobotanisches Phänomen Neukaledonien. - Bibliotheca diatomol. 38: 1-464.

Müller, O. (1910): Bacillariaceen aus dem Nyassalande und einigen benachbarten Gebieten. In: Beiträge zur Flora von Afrika. XXXVII. Berichte über die botanischen Ergebnisse der Nyassa-See und Kinga-Gebirgs-Expedition der Hermann- und Elise- geb. Heckmann-WentzelStiftung. - Engler's Bot. Jahrb. 45: 69-122.

Palmer, M.A. \& Roy, D.B. (2001): An estimate of the extent of dystrophic, oligotrophic, mesotrophic and eutrophic standing fresh water in Great Britain. - 36 pp., JNCC Report 317, Joint Nature Conservation Committee, Peterborough. (available at http://www.jncc.gov.uk/ pdf/jncc317 text.pdf).

PAtrick, R.M. (1959): New subgenera and two new species of the genus Navicula (Bacillariophyceae). - Notulae Naturae 324: 1-11.

Patrick, R.M. \& Reimer, C.W. (1966): The diatoms of the United States, exclusive of Alaska and Hawaii. Vol. 1: Fragilariaceae, Eunotiaceae, Achnanthaceae, Naviculaceae. - Monogr. Acad. Nat. Sci. Philad. 13: 1-688.

Plunkett, G.M., Whitehouse, N.J., Hall, V.A., Brown, D.M. \& Baillie, M.G.L. (2004): A preciselydated lake-level rise marked by diatomite formation in northeastern Ireland. - J. Quaternary Sci. 19: 3-7.

Potapova, M. \& Charles, D.F. (2004): Potential use of rare diatoms as environmental indicators in U.S.A. rivers. - In: Poulin, M. (ed.): Proceedings of the 17th International Diatom Symposium, 281-295pp., Biopress Limited, Bristol.

PoulíčKovÁ, A. \& Mann, D.G. (2006): Sexual reproduction in Navicula cryptocephala (Bacillariophyceae). - J. Phycol. 42: 872-886.

PoulíčKová, A., Mayama, S., Chepurnov, V.A. \& MAnN, D.G. (2007). Heterothallic auxosporulation, incunabula and perizonium in Pinnularia (Bacillariophyceae). - Eur. J. Phycol. 42: 367390.

Reavie, E.D. \& SMol, J.P. (1998): Freshwater diatoms from the St. Lawrence River. - Bibliotheca diatomol. 41: 1-137.

Reichardt, E. (1997): Morphologie und Taxonomie wenig bekannter Arten aus der Sammelgattung Navicula (excl. Navicula sensu stricto). - Diatom Res. 12: 299-320. 
Ross, R. (1963): The diatom genus Capartogramma and the identity of Schizostauron. - Bull. Brit. Mus. (Nat. Hist.), Bot. 3: 47-92.

Round, F.E. (1953): An investigation of two benthic algal communities in Malham Tarn, Yorkshire. - J. Ecol. 41: 174-179.

Round, F.E. (1957): The distribution of Bacillariophyceae on some littoral sediments of the English Lake District. - Oikos 8: 16-37.

Round, F.E. (1960): The epipelic algal flora of some Finnish lakes. - Arch. Hydrobiol. 57: 161-178.

Round, F.E., Crawford, R.M. \& Mann, D.G. (1990): The diatoms. Biology and morphology of the genera. -747 pp., Cambridge University Press, Cambridge.

Rumrich, U., Lange-Bertalot, H. \& Rumrich, M. (2000): Diatomeen der Anden von Venezuela bis Patagonien/Feuerland.- In: LANGe-BerTALOT, H. (ed.): Iconographia diatomologica. Annotated diatom micrographs. Vol. 9. Phytogeography-Diversity-Taxonomy. - 649 pp., Koeltz Scientific Books, Königstein, Germany.

Sapp, J., Carrapiço, F. \& Zolotonosov, M. (2002): Symbiogenesis: the hidden face of Constantin Merezhkowsky. - Hist. Phil. Life Sci. 24: 413440.

Sarno, D., Kooistra, W.H.C.F., Medlin, L.K., PerCOPO, I. \& Zingone, A. (2005): Diversity in the genus Skeletonema (Bacillariophyceae). II. An assessment of the taxonomy of $S$. costatum-like species with the description of four new species. - J. Phycol. 41: 151-176.

Schoeman, F.R. \& Archibald, R.E.M. (1976-1980): The diatom flora of southern Africa. - CSIR Special Report WAT 50, Pretoria, South Africa.

SimOnSEN, R. (1987): Atlas and catalogue of the diatom types of Friedrich Hustedt. 3 vols. - J. Cramer, Berlin \& Stuttgart.

Skvortzow, B.W. \& Meyer, C.I. (1928): A contribution to the diatoms of Baikal Lake. - Proc. Sungaree River Biol. Station 1(5):1-55.

Smith, W. (1853): A synopsis of British Diatomaceae, vol. 1. - 89 pp., J. Van Voorst, London.

Sмiтh, W. (1856): A synopsis of British Diatomaceae, vol. 2. - 107 pp., J. Van Voorst, London.

Stace, C.A. (1989): Plant taxonomy and biosystematics. Ed. 2. - Cambridge University Press, Cambridge.

Stafleu, F.A. \& Cowan, R.S. (1981): Taxonomic literature, vol. 3: LL-O, ed. 2. - 980 pp., Bohn, Scheltema \& Holkema, Utrecht.

TAYlOR, N.G. (1996): Variation within Sellaphora pupula (Bacillariophyta) in relation to the species concept. - 52 pp., MSc thesis, University of Edinburgh, Edinburgh, UK

Tilman, D. (1982): Resource competition and community structure. - Princeton University Press, Princeton, 296 pp.
Trobajo, R., Mann, D.G., Chepurnov, V.A., Clavero, E. \& Cox, E.J. (2006): Auxosporulation and size reduction pattern in Nitzschia fonticola (Bacillariophyta). - J. Phycol. 42: 1353-1372.

Tschermak-Woess, E. (1953): Über auffallende Strukturen in den Pyrenoiden einiger Naviculoideen. - Österr. Bot. Z. 100: 160-78.

Van de Vijver, B., Frenot, Y. \& Beyens, L. (2002): Freshwater diatoms from Ile de la Possession (Crozet Archipelago, Subantarctica). - Bibliotheca diatomol. 46: 1-412.

VAn Heurck, H. (1880-1885): Synopsis des Diatomées de Belgique. - Anvers.

Werum, M. \& Lange-Bertalot, H. (2004): Diatomeen in Quellen unter hydrogeologischen und anthropogenen Einflüssen in Mitteleuropa und anderen Regionen. - In: LANGe-Bertalot, H. (ed.): Iconographia diatomologica. Annotated diatom micrographs. Vol. 13. Ecology-Hydrology-Taxonomy. - 3-417 pp., A.R.G. Gantner, Ruggell, Liechtenstein.

(C) Czech Phycological Society (2008)

Received December 31, 2007

Accepted February 11, 2008 
